\title{
MINERALOGICAL AND METALLURGICAL STUDY OF SUPERGENE ORES OF THE MIKE CU-AU(-ZN) DEPOSIT, CARLIN TREND, NEVADA
}

\author{
by \\ Isabel F. Barton \\ Copyright (C) Isabel Barton 2017

\begin{abstract}
A Thesis Submitted to the Faculty of the
DEPARTMENT OF MINING AND GEOLOGICAL ENGINEERING

In Partial Fulfillment of the Requirements

For the Degree of

MASTER OF SCIENCE

In the Graduate College
\end{abstract}

THE UNIVERSITY OF ARIZONA

2017 


\section{STATEMENT BY AUTHOR}

The thesis titled Mineralogical and Metallurgical Study of Supergene Ores of the Mike Cu-Au(-Zn) Deposit, Carlin Trend, Nevada prepared by Isabel F. Barton has been submitted in partial fulfillment of requirements for a master's degree at the University of Arizona and is deposited in the University Library to be made available to borrowers under rules of the Library.

Brief quotations from this thesis are allowable without special permission, provided that an accurate acknowledgement of the source is made. Requests for permission for extended quotation from or reproduction of this manuscript in whole or in part may be granted by the head of the major department or the Dean of the Graduate College when in his or her judgment the proposed use of the material is in the interests of scholarship. In all other instances, however, permission must be obtained from the author.

SIGNED: $\quad$ Isabel Barton

APPROVAL BY THESIS DIRECTOR

This thesis has been approved on the date shown below:

Dr. Jaeheon Lee

Defense date $5 / 9 / 2017$

Professor, Department of Mining

and Geological Engineering 
Table of Contents

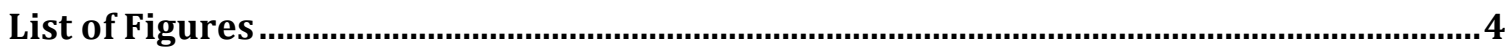

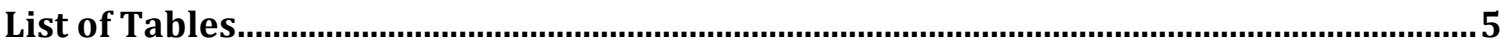

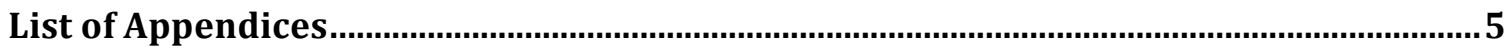

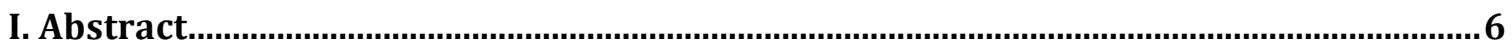

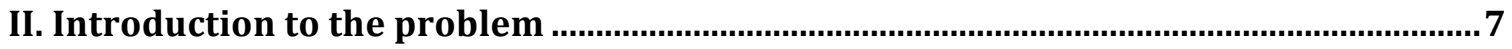

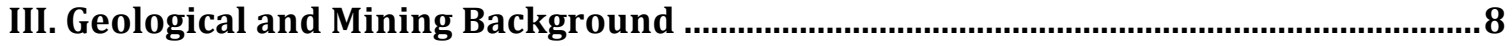

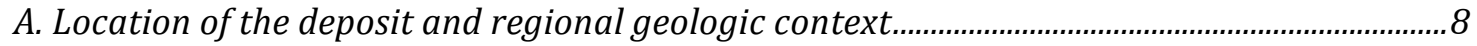

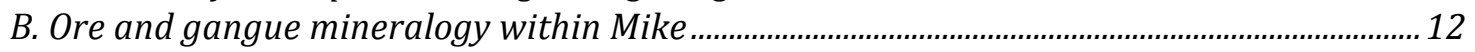

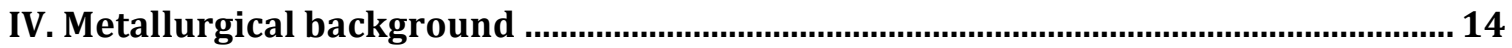

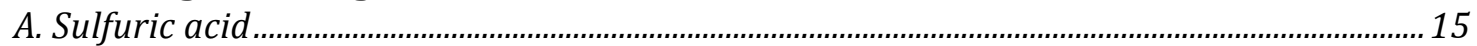

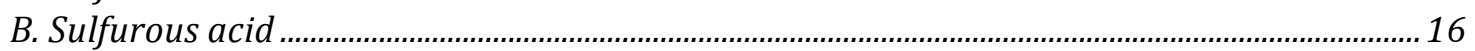

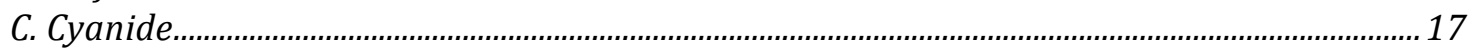

D. Thiourea

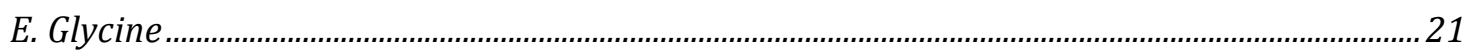

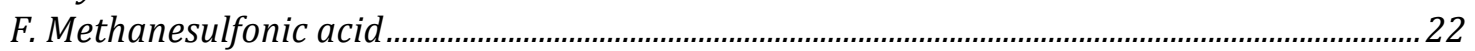

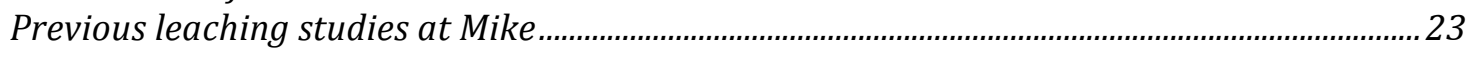

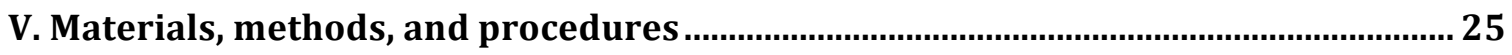

A. Sample prep

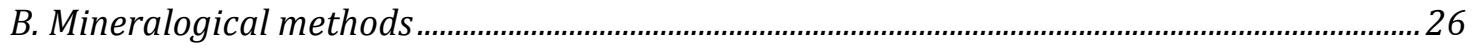

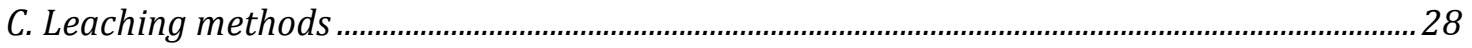

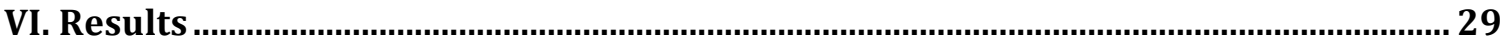

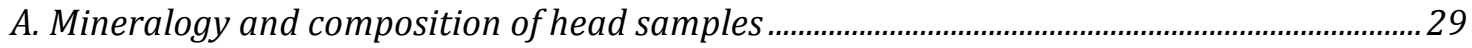

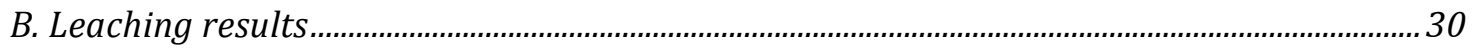

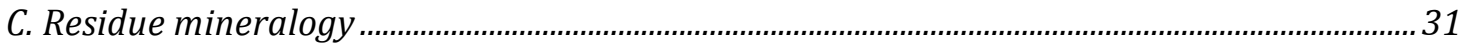

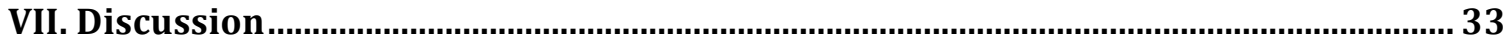

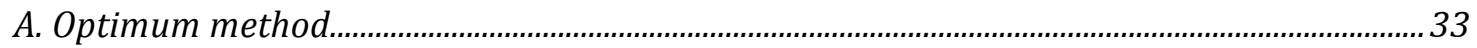

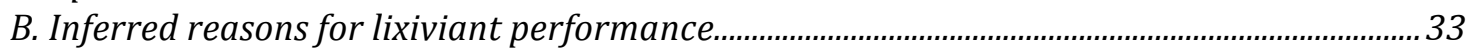

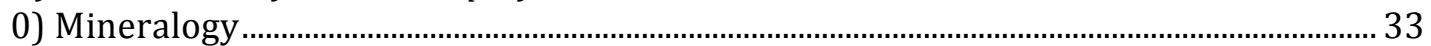

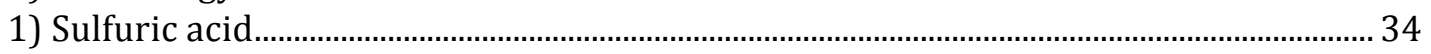

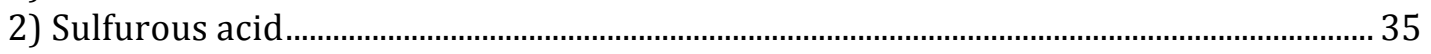

3) Cyanide

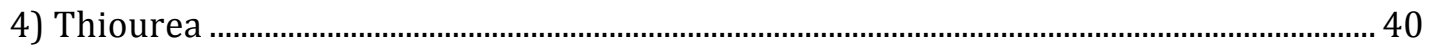

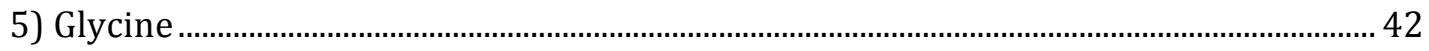

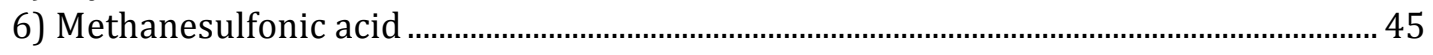

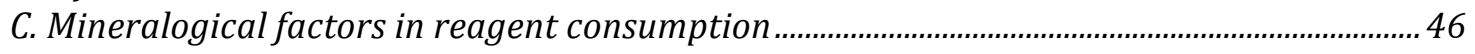

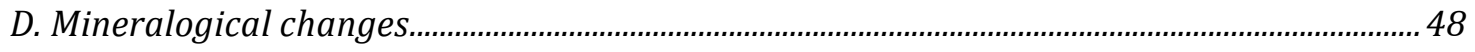

E. Reconciliation and sources of error

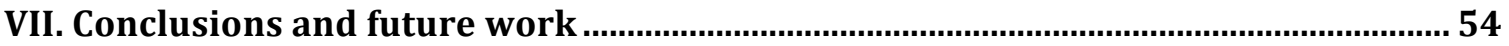

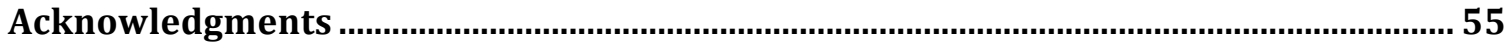

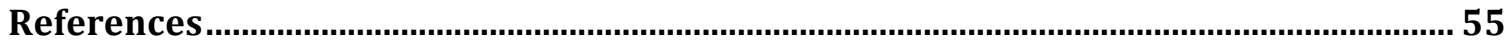




\section{List of Figures}

1. Location map of the Carlin trend, showing Mike in the Maggie Creek district. Modified from Norby and Orobona (2002) ................................61

2. Simplified geologic map of the Maggie Creek district. Modified from Teal and

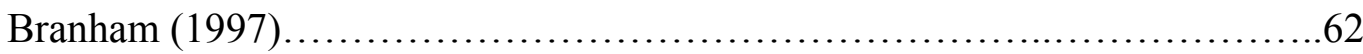

3. Cross section of Mike showing the distribution of $\mathrm{Au}, \mathrm{Cu}$, and $\mathrm{Zn}$ grade shells. Modified from Norby and Orobona (2002)

4. Distribution of conichalcite and chrysocolla in cross section, modified from Bawden (2002).

5. Stacked area charts showing the identities and proportions of minerals in the gangue (top) and ore (bottom) from the six samples taken from Mike. The lower chart has been normalized to $100 \%$ and does not reflect the $\mathrm{Cu}$ grade of the samples.

6. A: Bar chart of $\mathrm{Cu}$ recovery for all samples after leaching for 24 hours

B: Bar chart of Au recovery for all samples after leaching for 24 hours

7. Bar charts showing the total reagent consumption for sulfuric acid, cyanide, thiourea, and glycine after leaching for 24 hours. Sulfurous and methanesulfonic acids are not shown as no reagent was added over the course of each test $(\mathrm{pH}$

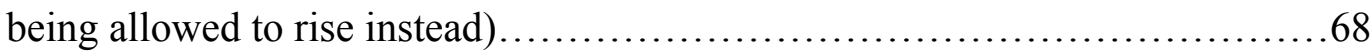

8. Changes in $\mathrm{Cu}$ mineralogy between head and residue samples..................69

9. Comparison of the chemical compositions of samples as evaluated by QEMSCAN and assays. Dashed lines have a slope of one and represent perfect correspondence between assays and QEMSCAN .70 
10. Illustrative examples of $\mathrm{Cu}$ and $\mathrm{Au}$ extraction kinetics over time for selected samples.

\section{List of Tables}

Table 1. Summary of reagents and conditions tested in this study.....

Table 2. Mineralogical characteristics of samples tested in Newmont's sulfuric acid leaching tests.

Table 3a. Copper recovery from (A) Newmont's sulfuric acid leaching bottle roll tests and (B) sulfuric acid column leaching tests..................................73

Table 4. Locations and grades of samples used in this study ........................73

Table 5. Iron, copper, and arsenic content of alunite, jarosite, and iron oxides in the Mike

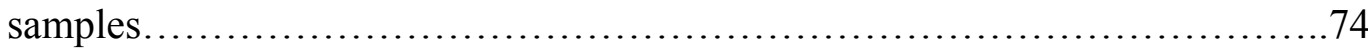

Table 6. Results of a QEMSCAN study of the Mike head samples......................75

Table 7. Results of bottle roll testing in this study .................................76

Table 8. Mineralogy of residue samples based on QEMSCAN study of the remains of -10 mesh splits for (A) sulfuric acid, (B) sulfurous acid, (C) cyanide, (D) thiourea, (E) glycine, and (F) methanesulfonic acid.................................... 78

\section{List of Appendices}
A. Detailed methods for bottle roll testing for each lixiviant.
B. Full results of leaching tests.
C. Elemental assays of residue samples. 
PREPUBLICATION MANUSCRIPT

Mineralogical and Metallurgical Study of Supergene Ores of the Mike $\mathrm{Cu}-\mathrm{Au}(-\mathrm{Zn})$

Deposit, Carlin Trend, Nevada

Isabel Barton, Junmo Ahn, Jaeheon Lee

\section{Abstract}

This paper presents the results of a mineralogical and metallurgical study of supergene ores at the Mike $\mathrm{Cu}-\mathrm{Au}(-\mathrm{Zn})$ deposit on the Carlin trend of Nevada, USA, currently held by Newmont Gold. With a metal endowment totaling >8.5 M oz. Au, 1027 M lbs. Cu, and $809 \mathrm{M}$ lbs. Zn, Mike is one of the largest deposits on the Carlin trend, but it is currently undeveloped. This study was undertaken as a first step toward finding an economic method of recovering both its $\mathrm{Cu}$ and $\mathrm{Au}$ by 1) comparing the metal recoveries achieved from the supergene ores by six different lixiviants, and 2) identifying which minerals failed to dissolve in each lixiviant. The reagents selected were sulfuric, sulfurous, and methanesulfonic acids, to recover $\mathrm{Cu}$, and cyanide, thiourea, and glycine, to recover $\mathrm{Cu}$ and $\mathrm{Au}$.

QEMSCAN and SEM study of six samples of different ore types and grades indicate that the Au occurs as varieties of native gold, including auricupride and electrum. Major $\mathrm{Cu}$ minerals are native $\mathrm{Cu}$, cuprite, malachite, chrysocolla, and conichalcite ( $\mathrm{Ca}-\mathrm{Cu}$ arsenate), with locally significant $\mathrm{Cu}$ in jarosite and goethite. Gangue mineralogy is dominated by quartz, sericite, chlorite, alunite, smectite and kaolinite, K-feldspar, jarosite, and iron oxides. 
Bottle roll testing indicates that no single-step leaching process is likely to provide economic recovery of both $\mathrm{Cu}$ and $\mathrm{Au}$. Sulfuric and methanesulfonic acid both recovered $>70 \%$ of the $\mathrm{Cu}$ except from the samples dominated by conichalcite, which was not leached effectively by any of the reagents tested. Only cyanide and thiourea recovered significant Au. Reagent consumption for cyanide, sulfuric acid, and methanesulfonic acid was generally within acceptable levels. Glycine and sulfurous acid are both uneconomic based on low recovery. Further work will focus on developing an economic process in two steps.

Mineralogical study of QEMSCAN residue indicates that the non-leaching ore minerals are conichalcite and $\mathrm{Cu}$-bearing Fe oxides. In addition, native $\mathrm{Cu}$ and cuprite do not leach well in glycine and chrysocolla does not leach well in thiourea or cyanide. Other observed mineralogical changes include the total loss of dolomite and partial loss of alunite and iron oxide from all samples, with apparent gains in jarosite.

\section{Introduction to the problem}

Thanks to the relatively high grades of both metals, $\mathrm{Cu}$ and Au contribute roughly equally to the value of any given ton of ore-bearing material in the supergene zone at Mike. As a result, the most economically favorable metallurgical processing scheme for the resource is one that could recover $70 \%$ or more of both metals, preferably by leaching, which is the cheapest method.

Finding such a processing technique would be the ideal outcome of this project. The less ambitious and perhaps more likely objective is to understand how the ore and 
gangue mineralogy react with different potential lixiviants, and which ore minerals resist dissolution in each possible leaching reagent.

This paper begins with an introduction to the geology and mineralogy of the Mike deposit, principally focused on the supergene zone. There follows a background to general hydrometallurgy, including the lixiviants tested here. The remainder of the Methods section focuses on sample preparation and mineralogical evaluation by QEMSCAN and SEM. Mineralogical and metallurgical results are presented after these, and then the mineralogy of the leach residues. These results, and the observed mineralogical changes, are then discussed to understand the mineralogical causes of the metallurgical results for each lixiviant tested.

\section{Geological and Mining Background}

\section{A. Location of the deposit and regional geologic context}

The Mike prospect, currently undeveloped, is a blind $\mathrm{Cu}-\mathrm{Au}(-\mathrm{Zn})$ deposit in the Maggie Creek district in Nevada's Carlin trend (Fig. 1). The Carlin trend is a series of Au districts and deposits strung out in tectonic windows along a 60-km-long northwesterly structural zone in the Basin and Range province of northern Nevada. The deposits formed approximately 42 to 36 million years ago from incursion of a low-salinity, carbonate-rich

alkaline fluid of uncertain and much-debated origin (Hofstra et al., 1999) along faults into limy sedimentary rocks. The majority of the host rocks are Paleozoic carbonates and shales of the lower plate of the Roberts Mountains thrust, with the Silurian-Devonian Roberts Mountains and the Devonian Popovich Formations hosting most of the ore. The Devonian Rodeo Creek Formation can also be a locally significant ore host in some 
Carlin deposits. The Roberts Mountains Formation is a silty limestone that grades upward into the limestones of the Popovich Formation, and the Rodeo Creek Formation is a calcareous siltstone. All three are heavily altered in and around the ore deposits and in areas around them, mainly with argillization of silicate minerals, dissolution of carbonate minerals, and formation of jasperoid by deposition of silica (Cline et al., 2005). A few Carlin deposits also contain $\mathrm{Au}$ in dikes or small granodiorite stocks or in the Lower Ordovician siliciclastic rocks where they are thrust over the Rodeo Creek Formation (Teal and Jackson, 2002).

The Au in Carlin-type deposits occurs in auriferous pyrite and arsenopyrite and their marcasite equivalents, oxidized to varieties of native Au in the supergene zone (Teal and Jackson, 2002). Alteration and mineralization temperatures estimated from fluid inclusions range from 180 to $240^{\circ} \mathrm{C}$ (Cline et al., 2005). The gold minerals in Carlin deposits are commonly accompanied by orpiment, realgar, cinnabar, stibnite, and sulfosalts, indicating that the ore-bearing fluid also mobilized and deposited $\mathrm{Hg}, \mathrm{Sb}, \mathrm{As}$, $\mathrm{Bi}$, and other metals capable of traveling as bisulfide complexes in solution (Cline et al., 2005). Copper and other base metals may be present in grades of $<0.01 \%$ (Arehart, 1996).

Mike was discovered in the Maggie Creek district in 1989, and its resource eventually calculated at $>8.5 \mathrm{M}$ oz Au, $1027 \mathrm{M}$ lbs. $\mathrm{Cu}$, and $809 \mathrm{M}$ lbs. $\mathrm{Zn}$ - makes it one of the largest single resources both in the district and on the Carlin Trend (Norby and Orobona, 2002; Harlan et al., 2002). Occurring where the Soap Creek and Good Hope faults intersect (Fig. 2), the deposit consists of the Main Mike mineralization in the hanging wall, and the West Mike mineralization in the footwall, of the Good Hope fault. 
Each of these contains two main ore zones, a lower hypogene $\mathrm{Cu}-\mathrm{Au}-\mathrm{Zn}$ orebody and an upper supergene $\mathrm{Cu}$-Au zone (Fig. 3). The mineralized area has been partly delineated by drilling but remains open to the northwest.

The early geologic work established that Mike displays most of the characteristics of Carlin-type gold deposits, but also established that it contains numerous features that do not fit the deposit model and are unique on the Carlin trend. Formation of calc-silicate hornfels and secondary K-feldspar, marbleization of limestone, and other manifestations of moderate- to high-temperature hydrothermal alteration are widespread within the Roberts Mountains and Popovich Formations at Mike (Teal and Branham, 1997). Copper grades average $0.34 \%$ and locally reach $3 \%$, and $\mathrm{Zn}$ is present at an average grade of 2.13\% (Norby and Orobona, 2002; Bawden, 2002). The major faults at the center of the ore zone (Fig. 2) have been intruded by a series of lamprophyre dikes, which host minor amounts of the gold (Teal and Branham, 1997).

To explain these anomalous features, Teal and Branham (1997) invoked two separate mineralizing events. The first, in their model, deposited the $\mathrm{Cu}$ (and presumably Zn) during the Cretaceous and metamorphosed the host rocks to hornfels and marble with heat supplied by a local apophysis of the Marys Mountain intrusive complex to the southwest (Fig. 2). This was followed in the Tertiary by a typical Carlin-type episode that overprinted the $\mathrm{Cu}$ mineralization with $\mathrm{Au}$, and more recently by supergene alteration that oxidized the $\mathrm{Cu}$ and $\mathrm{Au}$ near the surface (Fig.3).

Norby and Orobona (2002) agreed that the $\mathrm{Cu}$ (and presumably $\mathrm{Zn}$ ) had been the first of two distinct mineralizing events, but they argued that the hypogene zone did not contain enough $\mathrm{Cu}$ to account for the rich supergene blanket. Rather, they posited that the 
secondary sulfides and oxides that account for most of the Mike $\mathrm{Cu}$ inventory were exotic, the product of oxidation and transport of the ores of an undiscovered porphyry $\mathrm{Cu}$ deposit somewhere up the hydrologic gradient. They fingered the southeastern corner of the Richmond Mountain stock, northwest of Mike, as the source for the $\mathrm{Cu}$.

Mike's only common zinc mineral is sphalerite, and sphalerite does not generally form by supergene processes, creating a problem for Norby and Orobona's exotic-Cu model. This was a major focus of a thesis by Bawden (2002) on the supergene mineralogy. Like the two contemporaneous articles, Bawden had concluded that Mike was the product of two episodes of mineralization, but he reversed their order. In his model, early Carlin-type gold mineralization was overprinted by later, exotic copper and zinc imported by supergene fluids migrating laterally from an distant $\mathrm{Cu}-\mathrm{Zn}$ deposit, which he also interpreted as a porphyry deposit. The $\mathrm{Cu}$ precipitated as chalcocite and the Zn, with bacterial sulfate reduction, as sphalerite (Bawden, 2002; Bawden et al., 2003). Although unconventional (and uncertain), this explanation accounted for several of the troublesome features of Mike: the mass imbalance between hypogene and supergene $\mathrm{Cu}$, the high-temperature alteration, and the abundance of $\mathrm{Cu}$ arsenates. It did, however, leave open the question of the feasibility of bacterial action precipitating $800+$ million pounds of supergene sphalerite.

A later thesis by Parrish (2014) examined the petrography of the hypogene ore minerals and also concluded that the base metals postdated the Carlin-type gold, but rejected the possibility of an exotic origin for most of the supergene $\mathrm{Cu}$. Instead, Parrish contended that the $\mathrm{Cu}$ and $\mathrm{Zn}$ had all been deposited as hypogene skarn mineralization around an undiscovered but proximal porphyry at depth to the north-northwest along the 
Good Hope fault. He also identified this putative porphyry with an apophysis of an equally hypothetical batholith that Ressel and Henry (2006) posited was the source for the Eocene intrusions of northeast Nevada. Subsequent oxidation by meteoric fluids produced the supergene mineralization observed.

Evaluating these competing hypotheses is beyond the scope of this study, which focuses on the metallurgy. For metallurgical purposes it suffices that the supergene mineralization consists of conichalcite-dominated $\mathrm{Cu}$ oxides (sensu lato) and native $\mathrm{Cu}$ with varieties of native $\mathrm{Au}$. The two metals are so closely linked in space that any metallurgical method used must be able to recover both metals from the same material. Nonetheless, a complete metallurgical and economic evaluation might conclude that (1) it is economic to recover only one of the elements, (2) a choice might need to be made as to whether a given increment of ore is treated for recovery of only one or the other element, (3) a two-step process is required to recover first one element and then another, or (4) that there are no viable methods for recovering enough metal to justify the cost of mining.

\section{B. Ore and gangue mineralogy within Mike}

Most of the data on Mike's gangue mineralogy come from the background paper written by Teal and Branham (1997), as the subsequent theses by Parrish (2014) and Bawden (2002) concentrate on the hypogene and supergene ores respectively.

The igneous dikes are quartz-poor and consist mainly of plagioclase, K-feldspar, biotite, hornblende, and pyrite, with minor olivine and pyroxene (Teal and Branham, 1997). In the Roberts Mountains and Popovich Formations, an original silty carbonate rock that probably consisted of calcite, micas, quartz, and clays has been metamorphosed 
and metasomatized to calcite, dolomite, quartz, K-feldspar, clinopyroxenes, amphiboles, and biotite (Teal and Branham, 1997). The mineralogy of the Rodeo Creek Formation is similar, although with less calcite and dolomite and more of the calc-silicates, probably reflecting a more siliciclastic protolith. All these were overprinted by metasomatic Kfeldspar and quartz (Teal and Branham, 1997). The subsequent Carlin-style mineralizing episode, besides adding silica and subtracting carbonate, also precipitated realgar and cinnabar (Parrish, 2014). The origin of the non-auriferous pyrite at Mike is uncertain but could belong to any of the alteration episodes or to multiple episodes (Parrish, 2014).

In his study of the hypogene ore mineralogy, Parrish identified arsenian pyrite and arsenopyrite as the major hypogene Au hosts, with the later base-metal deposition episode adding $\mathrm{Cu}$ as bornite and chalcopyrite, $\mathrm{Pb}$ as galena, and $\mathrm{Zn}$ as sphalerite. Additional $\mathrm{Cu}$ introduction later formed digenite, chalcocite, and covellite. In the supergene zone, Bawden (2002) identified $\mathrm{Cu}$ in conichalcite $\left(\mathrm{CaCu}\left(\mathrm{AsO}_{4}\right)(\mathrm{OH})\right)$, chrysocolla $\left(\mathrm{CuSiO}_{3} * \mathrm{nH}_{2} \mathrm{O}\right)$, cuprite $\left(\mathrm{Cu}_{2} \mathrm{O}\right)$, native $\mathrm{Cu}$, chalcocite $\left(\mathrm{Cu}_{2} \mathrm{~S}\right)$, malachite $\left(\mathrm{Cu}_{2} \mathrm{CO}_{3}(\mathrm{OH})_{2}\right)$, and $\mathrm{Cu}$-bearing kaolinite, montmorillonite, and halloysite in the supergene $\mathrm{Cu}$ ores. Of these, conichalcite and chrysocolla are by far the most common and widespread; Figure 4 shows their relative distributions. Oddly for a supergene $\mathrm{Cu}$ zone, tenorite and other black $\mathrm{Cu}$ oxides have never been verified at Mike, although some have been tentatively identified by Newmont geologists. Zinc is also strangely absent from the supergene zone, occurring only as $<0.1 \% \mathrm{Zn}$ in some of the iron oxides (Bawden, 2002). This mineralogy does not appear to vary consistently with gangue mineralogy or with rock type. 


\section{Metallurgical background}

The low grade and high strip ratio of the Mike supergene ores would make it prohibitively expensive to produce a concentrate, so heap leaching is the only viable processing and extraction method. However, mixed $\mathrm{Cu}-\mathrm{Au}$ ores are among the most problematic ore types in hydrometallurgy, especially when the $\mathrm{Cu}$ is present in oxidized minerals, which are more difficult to float with acceptable recovery (Muir et al., 1989; Vaughan, 2004). There are several studies of how to recover $\mathrm{Cu}$ and $\mathrm{Au}$ from such mixed oxide ores. Seredkin et al. (2014) recommended gravity and flotation, followed by two leaching steps. Mendes and Martins (2002) developed a two-stage leaching process for oxide $\mathrm{Cu}$ and gold at Igarapé Bahia, starting with sulfuric acid leaching to remove the $\mathrm{Cu}$ and proceeding to cyanidation for the Au. McInnes et al. (1989) suggested a similar process, but using thiourea rather than cyanide for the second step. Muir et al. (1989) review several options, including sulfidizing the ore in an autoclave and mixing it with kerosene before flotation and concentrate leaching.

Most of these processes are expensive compared to simple heap leaching, which is the most economic option at Mike. The optimal objective of this study is to find a leaching technique that can effectively recover $\mathrm{Cu}$ and $\mathrm{Au}$ from the supergene ore minerals without excessive reagent consumption or liberation of deleterious elements. A more feasible objective is to evaluate how various potential leaching reagents interact with the range of supergene ores at Mike. Six lixiviants were tested (Table 1). Sulfuric, sulfurous, and methanesulfonic acids were used to recover $\mathrm{Cu}$, cyanide to recover $\mathrm{Au}$, and thiourea and glycine to recover both. The following section briefly describes the mechanisms and previous usage of each reagent. 


\section{A. Sulfuric acid}

The standard means of leaching $\mathrm{Cu}$ oxides (sensu lato) is dissolution in sulfuric acid. This originated, likely by accident, in the recovery of $\mathrm{Cu}$ from the acidic waters produced by rainfall on pyrite-bearing mine waste around Rio Tinto in Spain during the 1500s (Habashi, 2005). Since then, sulfuric acid leaching has developed into the principal modern technique for recovering $\mathrm{Cu}$ from its supergene ore minerals. Copper is liberated by reactions such as:

(1) $\mathrm{Cu}_{2} \mathrm{CO}_{3}(\mathrm{OH})_{2}+2 \mathrm{H}_{2} \mathrm{SO}_{4} \rightarrow 2 \mathrm{Cu}^{2+}+2 \mathrm{SO}_{4}{ }^{2-}+\mathrm{CO}_{2}+3 \mathrm{H}_{2} \mathrm{O}$

and

(2) $\mathrm{CuSiO}_{3} * 2 \mathrm{H}_{2} \mathrm{O}+\mathrm{H}_{2} \mathrm{SO}_{4} \rightarrow \mathrm{Cu}^{2+}+\mathrm{SO}_{4}{ }^{2-}+\mathrm{SiO}_{2} \cdot 2 \mathrm{H}_{2} \mathrm{O}+\mathrm{H}_{2} \mathrm{O}$

for malachite and chrysocolla respectively, and analogous reactions for other complex oxides of $\mathrm{Cu}$. Because of the ready solubility of most supergene $\mathrm{Cu}$ minerals in sulfuric acid, standard $\mathrm{Cu}$ recoveries from it are commonly $>85 \%$. Only two $\mathrm{Cu}$ minerals, native $\mathrm{Cu}$ and cuprite, pose significant challenges to sulfuric acid leaching. The first mole of $\mathrm{Cu}$ in cuprite dissolves readily in acid, but the second mole of $\mathrm{Cu}$ dissolves slowly, and native copper not at all, unless an oxidant such as $\mathrm{O}_{2}$ or $\mathrm{Fe}^{3+}$ is present:

(3) $\mathrm{Cu}+0.5 \mathrm{O}_{2}+\mathrm{H}_{2} \mathrm{SO}_{4} \rightarrow \mathrm{Cu}^{2+}+\mathrm{SO}_{4}{ }^{2-}+\mathrm{H}_{2} \mathrm{O}$

(4) $\mathrm{Cu}+2 \mathrm{Fe}^{3+} \rightarrow \mathrm{Cu}^{2+}+2 \mathrm{Fe}^{2+}$, and

(5) $\mathrm{Cu}_{2} \mathrm{O}+\mathrm{H}_{2} \mathrm{SO}_{4} \rightarrow \mathrm{Cu}^{2+}+\mathrm{SO}_{4}{ }^{2-}+\mathrm{H}_{2} \mathrm{O}+\mathrm{Cu}$.

Both moles of $\mathrm{Cu}$ in cuprite are nominally soluble in sulfuric acid, so the very slow dissolution in practice of the second mole has led to considerable study. Sullivan (1933) attributed it to the surface passivation caused by the native $\mathrm{Cu}$ layer formed by the 
incongruent dissolution, but this process did not match the linear rate law observed in a separate study by Wadsworth and Wadia (1956); moreover the native $\mathrm{Cu}$ formed was so porous that it could not effectively passivate the surface. Wadsworth and Wadia proposed instead that the adsorption of sulfuric acid on the cuprite surface, which Majima et al. (1989) modified to reflect adsorption of $\mathrm{H}+$ on the surface. The reasons for it, however, remain uncertain.

A major drawback of sulfuric acid is that it cannot dissolve Au minerals, so in this study it was tested for $\mathrm{Cu}$ leaching only.

\section{B. Sulfurous acid}

Sulfurous acid (nominally $\mathrm{H}_{2} \mathrm{SO}_{3}$, although there is no evidence that the compound form exists in solution it is frequently called aqueous $\mathrm{SO}_{2}$ ), has been investigated for several decades for its potential role in hydrometallurgy. Thanks to the multiplicity and versatility of sulfite species in solution, sulfurous acid behaves variously as a reducing agent, an acid, a ligand, and a catalyst (Youzbashi and Dixit, 1993; Gbor et al., 2002). It has been suggested as an effective lixiviant for reductive leaching of $\mathrm{Cu}$ from copper wad (J. Hiskey, pers. comm., 2017), for iron in iron oxides (Warren and Hay, 1975), for nonferrous base metals in iron oxides (Kumar et al., 1993), for base metals from slag (Ahmed et al., 2000), as a reductant in leaching Ni and Co from laterite ores (Das and de Lange, 2011), and as a substitute for sulfuric acid in dissolving cupriterich copper ores (Youzbashi and Dixit, 1993). In the last-named case, sulfurous acid produced $\mathrm{Cu}$ recoveries of 70 to $98 \%$ for various size fractions. 
Dissolution of $\mathrm{Cu}$ minerals in sulfurous acid occurs via reactions that are similar to those representing their dissolution in sulfuric acid, e.g.,

(6) $\mathrm{Cu}_{2} \mathrm{CO}_{3}(\mathrm{OH})_{2}+2 \mathrm{H}_{2} \mathrm{SO}_{3} \rightarrow 2 \mathrm{Cu}^{2+}+2 \mathrm{SO}_{3}^{2-}+\mathrm{CO}_{2}+3 \mathrm{H}_{2} \mathrm{O}$

for malachite, and analogous reactions for other $\mathrm{Cu}$ species. For cuprite, the hypothesized reaction is:

(7) $2 \mathrm{Cu}_{2} \mathrm{O}+2 \mathrm{SO}_{2(\mathrm{aq})}+\mathrm{H}_{2} \mathrm{O} \rightarrow 2 \mathrm{Cu}_{2} \mathrm{SO}_{3}+2 \mathrm{H}^{+}$.

As with sulfuric acid leaching, Au minerals are not soluble in sulfurous acid and this reagent was tested solely for its effectiveness at $\mathrm{Cu}$ leaching.

\section{Cyanide}

That cyanide could dissolve gold was discovered in the late 1700s in Sweden, but cyanide was not used in large-scale metallurgical processes until after 1887, when the cyanidation process for gold extraction was patented. In the following 20 years, global Au production doubled as cyanidation replaced chlorination in the gold industry (Habashi, 1987; Hilson and Monhemius, 2006). Cyanidation remains the dominant $\mathrm{Au}$ extraction method today.

The basic reaction is:

(8) $2 \mathrm{Au}+4 \mathrm{CN}^{-}+0.5 \mathrm{O}_{2}+\mathrm{H}_{2} \mathrm{O} \rightarrow 2 \mathrm{Au}(\mathrm{CN})_{2}^{-}+2 \mathrm{OH}^{-}$.

Because native $\mathrm{Au}$ is the major gold ore at many deposits, this process suffices without further addition for many operations. Where Au occurs in pyrite or arsenopyrite, the ore is usually roasted or otherwise treated prior to leaching. This oxidizes the sulfide and leaves the $\mathrm{Au}$ as native gold. 
Cyanide is also capable of dissolving $\mathrm{Cu}$ from most supergene oxide minerals by the reactions:

(9) $\mathrm{Cu}_{2} \mathrm{CO}_{3}(\mathrm{OH})_{2}+7 \mathrm{NaCN} \rightarrow 2 \mathrm{Na}_{2} \mathrm{Cu}(\mathrm{CN})_{3}+\mathrm{H}_{2} \mathrm{O}+\mathrm{Na}_{2} \mathrm{CO}_{3}+\mathrm{NaCNO}$, and

(10) $\mathrm{Cu}_{2} \mathrm{O}+6 \mathrm{NaCN}+\mathrm{H}_{2} \mathrm{O} \rightarrow 2 \mathrm{Na}_{2} \mathrm{Cu}(\mathrm{CN})_{3}+2 \mathrm{NaOH}$.

In most circuits the solubility of $\mathrm{Cu}$ in cyanide is more a problem than an asset. Although chrysocolla is only about $12 \%$ soluble in cyanide, other common supergene $\mathrm{Cu}$ minerals are $85 \%$ soluble or more (Hedley and Tabachnick, 1958; Lower and Booth, 1965; Sceresini, 2005). Because $\mathrm{Cu}(\mathrm{CN})_{3}{ }^{2-}$ and $\mathrm{Cu}(\mathrm{CN})_{4}{ }^{3-}$ are the dominant $\mathrm{Cu}$-cyanide complexes at alkaline $\mathrm{pH}$, each $\mathrm{kg}$ of $\mathrm{Cu}$ dissolved consumes $2.32 \mathrm{~kg}$ of $\mathrm{NaCN}$. Minerals containing cupric ion contribute to additional cyanide loss, since $\mathrm{Cu}^{2+}$ in cyanide solution decomposes to $\mathrm{Cu}^{+}$and cyanate $\left(\mathrm{CNO}^{-}\right)$, from which cyanide is unrecoverable (Sceresini, 2005; Botz et al., 2011). This leads to another $0.4 \mathrm{~kg} \mathrm{NaCN}$ lost for each $\mathrm{kg}$ of $\mathrm{Cu}$ dissolved as cupric ion (Lower and Booth, 1965). For malachite dissolution, cyanate formation accounts for virtually all the observed reagent consumption (Lower and Booth, 1965).

Copper dissolves in cyanide much faster than gold (notwithstanding that gold is nominally the more stable complex), with most $\mathrm{Cu}$ dissolving within the first six hours of leaching. This renders it virtually impossible to leach Au selectively with cyanide, so the only viable means of cyanide-leaching a $\mathrm{Cu}$-rich $\mathrm{Au}$ ore is to ensure that the $\mathrm{CN}: \mathrm{Cu}$ mole ratio stays above $4: 1$. Because of this, high cyanide consumption is a significant economic problem in gold-leaching circuits (Lower and Booth, 1965).

The preg-robbing potential of $\mathrm{Cu}$ minerals is their most prominent feature in most discussions of $\mathrm{Cu}-\mathrm{Au}$ leaching, for good reason. An additional side effect, Au leaching by 
$\mathrm{Cu}(\mathrm{CN})_{3}{ }^{2-}$, also deserves to be mentioned. Muir et al. (1989) and Vukcevic (1996) both observed that small amounts of $\mathrm{Cu}$ under oxidizing conditions could lead to additional Au dissolution by the reaction:

(11) $4 \mathrm{Au}+8 \mathrm{Cu}(\mathrm{CN})_{3}{ }^{2-}+\mathrm{O}_{2}+2 \mathrm{H}_{2} \mathrm{O} \rightarrow 4 \mathrm{Au}(\mathrm{CN})_{2}{ }^{-}+8 \mathrm{Cu}(\mathrm{CN})_{2}{ }^{-}+4 \mathrm{OH}^{-}$

with the highly complexed $\mathrm{Cu}$ in solution giving up one cyanide group to dissolve the Au (Tran et al., 1997; Breuer et al., 2005).

\section{Thiourea}

The toxicity of cyanide, demonstrated in several high-profile accidental releases from mines, has led to an increasing search for viable alternatives (Hilson and Monhemius, 2006). Thiourea, $\mathrm{SCN}\left(\mathrm{NH}_{2}\right)_{2}$, was found to be an effective means of stripping $\mathrm{Au}$ into the aqueous phase in cyanide circuits in the 1940s and 1950s, and the 1960s saw some early investigations into its use as a leaching agent (e.g. Groenewald, 1976). A particular advantage of thiourea is that it reacts with Au substantially faster than cyanide, speeding up the leaching process, so that Au recovery in thiourea may be close to $100 \%$ within an hour (Chen et al., 1980). Despite continuing work, the mining industry makes limited use of thiourea in leaching owing to the greater economic advantages of cyanide (Hiskey and Atluri, 1988). Li and Miller (2006) provide a review of the development of thiourea leaching and applications.

The major reaction for dissolving gold is:

(12) $\left.\mathrm{Au}+2 \mathrm{SCN}\left(\mathrm{NH}_{2}\right)_{2} \rightarrow \mathrm{Au}\left(\mathrm{SCN}\left(\mathrm{NH}_{2}\right)_{2}\right)\right)^{+}+\mathrm{e}^{-}$.

This reaction requires oxidizing conditions, which are generally supplied by an oxidant such as hydrogen peroxide or $\mathrm{Fe}^{3+}$, which accepts the electron; $\mathrm{O}_{2}$ by itself is not 
oxidizing enough (Lacoste-Bouchet et al., 1998). Groenewald (1976) found $\mathrm{Fe}^{3+}$ a more effective oxidant than peroxide, whether added as one of the reagents or leached from the sample as $\mathrm{Fe}^{2+}$ and then oxidized. This is probably because $\mathrm{Fe}^{3+}$, unlike peroxide, can form a stable aqueous complex with thiourea, enabling the solution to be maintained at high oxidation potential with low thiourea consumption (Li and Miller, 2006, 2007). Without ferric ion, compounds produced by the oxidative decomposition of thiourea passivate the surfaces of minerals and prevent them from leaching (Hiskey and Atluri, 1988; Li and Miller, 2006). However, some oxidation is beneficial: the oxidation of thiourea to formamidine disulfide, which acts as the oxidizing and leaching agent for $\mathrm{Au}$, greatly enhances Au recovery by thiourea leaching (Hiskey and Atluri, 1988).

The full reaction, with ferric iron as an oxidant, is:

(13) $\mathrm{Au}+2 \mathrm{SCN}\left(\mathrm{NH}_{2}\right)_{2}+\mathrm{Fe}^{3+} \rightarrow \mathrm{Au}\left(\mathrm{SCN}\left(\mathrm{NH}_{2}\right)_{2}\right)^{+}+\mathrm{Fe}^{2+}$.

Despite the use of $\mathrm{Fe}^{3+}$ as an oxidant, thiourea consumption is still prohibitively high thanks to a combination of oxidative decomposition, thermal degradation, adsorption onto mineral surfaces, and complexation with metals (Filmer et al., 1984; Li and Miller, 2006). Of all minerals examined, sulfides and hematite were found to adsorb thiourea most strongly, but their major contribution to thiourea consumption was releasing $\mathrm{Fe}^{3+}$, which helped oxidize and decompose the thiourea (Li and Miller, 2006). Other base metals did not have this effect and did not complex with thiourea, so the consumption of thiourea (and recovery of those metals) was negligible. The one exception was copper, which $\left(\mathrm{as}^{2+}\right)$ oxidizes thiourea and formamidine disulfide and catalyzes their oxidation by $\mathrm{Fe}^{3+}$, and which $\left(\mathrm{as} \mathrm{Cu}^{+}\right)$decomposes thiourea to elemental sulfur, which passivates $\mathrm{Au}$ surfaces (Krzewska and Podsiadly, 1980). The $\mathrm{Cu}^{+}$ion can 
also form stable complexes with thiourea, leading to additional thiourea consumption or, from a different perspective, potential Cu recovery (Javet and Hintermann, 1969; Krzewska et al., 1980). This makes thiourea, along with cyanide, one of a small number of reagents worth testing for potential economic recovery of both $\mathrm{Cu}$ and $\mathrm{Au}$.

\section{E. Glycine}

Among alternative lixiviants for Au leaching, thiourea is closer to being widespread in industrial use, but glycine (amino acid, $\mathrm{C}_{2} \mathrm{H}_{5} \mathrm{NO}_{2}$ ) has also been mooted. Easily broken down by enzymes, glycine is nontoxic and environmentally safe (Oraby and Eksteen, 2014). The literature on glycine use in leaching is considerably less extensive than the corresponding body of work on thiourea, let alone cyanide, but the last two decades have worked out the basic reaction mechanisms. For gold, the dissolution reaction is:

(14) $\mathrm{Au}+2\left(\mathrm{NH}_{2} \mathrm{CH}_{2} \mathrm{COOH}\right)+\mathrm{OH}^{-} \rightarrow \mathrm{Au}\left(\mathrm{NH}_{2} \mathrm{CH}_{2} \mathrm{COO}\right)_{2}{ }^{-}+\mathrm{H}_{2} \mathrm{O}$.

The exact mechanism of Au dissolution is uncertain; it is possible that it is the peroxide that actually dissolves the $\mathrm{Au}$ and that the role of glycine is to chelate it, keeping it stable in solution (Oraby and Eksteen, 2015). The reaction does not appear to depend on $\mathrm{O}_{2}$ in solution but is controlled by the rate of the chemical reaction and is considerably slower than Au dissolution in cyanide (Oraby and Eksteen, 2015).

Glycine is also capable of dissolving most supergene $\mathrm{Cu}$ minerals, and in fact is used to enhance $\mathrm{Cu}$ dissolution in several industrial systems (Aksu and Doyle, 2001). Dissolution reactions for cuprite, malachite, and chrysocolla are

$$
\text { (15) } \mathrm{Cu}_{2} \mathrm{O}+2 \mathrm{H}^{+}+4 \mathrm{H}_{2} \mathrm{NCH}_{2} \mathrm{OO}^{-} \rightarrow 2 \mathrm{Cu}\left(\mathrm{H}_{2} \mathrm{NCH}_{2} \mathrm{OO}\right)_{2}{ }^{-}+2 \mathrm{H}_{2} \mathrm{O}
$$


(16) $\mathrm{Cu}_{2} \mathrm{CO}_{3}(\mathrm{OH})_{2}+4\left(\mathrm{NH}_{2} \mathrm{CH}_{2} \mathrm{COOH}\right)+2 \mathrm{OH}^{-} \rightarrow 2 \mathrm{Cu}\left(\mathrm{NH}_{2} \mathrm{CH}_{2} \mathrm{COO}\right)_{2}+4 \mathrm{H}_{2} \mathrm{O}$

$+\mathrm{CO}_{3}{ }^{2-}$, and

(17) $\mathrm{CuSiO}_{3} \bullet 2 \mathrm{H}_{2} \mathrm{O}+2\left(\mathrm{NH}_{2} \mathrm{CH}_{2} \mathrm{COOH}\right) \rightarrow \mathrm{Cu}\left(\mathrm{NH}_{2} \mathrm{CH}_{2} \mathrm{COO}\right)_{2}+3 \mathrm{H}_{2} \mathrm{O}+\mathrm{SiO}_{2}$.

Cuprite, native $\mathrm{Cu}$, malachite, and azurite are completely glycine-soluble in theory, although in at least one case $\mathrm{Cu}$ recovery from cuprite by glycine leaching never exceeded 83.8\% (Aksu and Doyle, 2001; Tanda et al., 2017). Chrysocolla tends to be the most problematic of the common $\mathrm{Cu}$ oxide minerals, with recovery consistently $<20 \%$ (Tanda et al., 2017).

Milants (1958) found that $\mathrm{Cu}$ dissolution in glycine proceeds by two steps, consisting first of the adsorption of oxygen to the mineral surface and then reaction of the glycinate anion with the resulting copper-oxygen complex. At low $\mathrm{P}_{\mathrm{O} 2}$ the rate of $\mathrm{O}_{2}$ transport to the mineral surface controls the overall reaction rate, but at high $\mathrm{P}_{\mathrm{O} 2}$ the rate of the glycinate-copper-oxide reaction controls the overall rate, which is independent of oxygen pressure (Milants, 1958). A strong oxidant, most commonly hydrogen peroxide, is required, since the only stable $\mathrm{Cu}$-glycinate species is cupric, and the cupric ion does not help oxidize $\mathrm{Cu}^{0}$ to $\mathrm{Cu}^{+}$(Milants, 1958; Halpern et al., 1959). However, $\mathrm{Cu}^{2+}$ does catalyze the dissolution of $\mathrm{Au}$ in glycine, for uncertain reasons (Eksteen and Oraby, 2015).

\section{F. Methanesulfonic acid}

Of all the reagents tested in this study, methanesulfonic acid (MSA), $\mathrm{CH}_{3} \mathrm{SO}_{3} \mathrm{H}$, is the newest and therefore the least studied. Copper is readily soluble in methanesulfonic acid. The copper oxides dissolve by reactions such as: 
(18) $\mathrm{Cu}_{2} \mathrm{CO}_{3}(\mathrm{OH})_{2}+4 \mathrm{CH}_{3} \mathrm{SO}_{3} \mathrm{H} \rightarrow 2 \mathrm{Cu}^{2+}+4 \mathrm{CH}_{3} \mathrm{SO}_{3}{ }^{-}+\mathrm{CO}_{2}+3 \mathrm{H}_{2} \mathrm{O}$.

The $\mathrm{Cu}$ may exist as cupric methanesulfonate, $\mathrm{Cu}\left(\mathrm{CH}_{3} \mathrm{SO}_{3}\right)_{2}$. According to $\mathrm{Ye}$ and Dow (2014), this compound is more stable in solution than cupric sulfate and is therefore less likely to reprecipitate $\mathrm{Cu}$ after leaching it. Baths of cupric methanesulfonate are commonly used in electroplating, since they provide a purer $\mathrm{Cu}$ coating than sulfuric acid (e.g. Low and Walsh, 2008).

Most of the literature on methanesulfonic acid deals with electroplating; there are very few studies of its efficiency as a leaching agent. Feng et al. (2015) found a maximum recovery of $84 \% \mathrm{Cu}$ from malachite using methanesulfonic acid at room temperature, with higher recoveries reached (up to $92 \%$ ) at increased temperature. The experiments took only 1 hour to reach maximum $\mathrm{Cu}$ extraction, signifying fast kinetics; Feng et al. (2015) concluded that diffusion controls the dissolution rate.

The only other study of methanesulfonic acid as a lixiviant consists of a series of dissolution tests on cerussite $\left(\mathrm{PbCO}_{3}\right)$ by Wu et al. (2014), which achieved $83-84 \%$ extraction in a few minutes and $98 \%$ extraction with additional re-processing steps. Methanesulfonic acid also featured in a study by Borra et al. (2015) comparing the effectiveness of different acids at recovering rare earth elements from the oxides left as waste during bauxite production. Recovery by methanesulfonic acid was 35 to $55 \%$, making MSA more effective than citric or acetic acid but less effective than nitric, hydrochloric, or sulfuric acids, which extracted up to $70 \%$ of the rare earth concentration in the samples.

Previous leaching studies at Mike 
Newmont conducted an internal study of sulfuric acid leaching on 10 samples of the Mike ore, finished in 2006. Of these samples, 8 were from the supergene zone and 2 were from the hypogene-supergene transition immediately below it. Gangue mineralogy was identified by semiquantitative XRD, with copper minerals identified by microscopic analysis (Table 2). However, the identification was limited to classifying minerals as native copper, malachite, or chalcocite/digenite rims on pyrite, based on grain color; chrysocolla, cuprite, and conichalcite are not mentioned in the report.

Newmont's leaching tests included bottle roll and column testing with sulfuric acid. Bottle roll tests were conducted with 500-g test charges of 200-mesh pulverized samples, rolled for 24 hours at $40 \%$ solids. The leaching solution was $10 \mathrm{~g} / \mathrm{L}$ sulfuric acid with $\mathrm{pH}$ maintained below 2.4. For column leach tests, composites crushed to $-1 / 2$ " were agglomerated and cured for five days with $30-50 \%$ of the amount of sulfuric acid consumed during bottle roll testing, to maintain 6-7\% moisture content. After agglomeration, the samples were loaded into a 5' $\mathrm{x} 8$ " column, which was then leached with $10 \mathrm{~g} / \mathrm{L}$ sulfuric acid at a flow rate of $10 \mathrm{~L} / \mathrm{hr} / \mathrm{m}^{3}$. Fresh leach solution was added daily. The tests lasted 56 days.

Table 3 shows the results of bottle roll and column tests. Copper extraction ranged from 31.2 to $73.1 \%$ for bottle roll and from 67.1 to $86.5 \%$ for column leach tests. Bottle roll $\mathrm{Cu}$ recovery did not correlate with the results of $\mathrm{Cu}$ quick leach tests for acid-soluble copper, whereas column leach test data did correlate with the fraction of QLT copper measured. Bottle roll and leach tests $\mathrm{Cu}$ recoveries for the different samples did not correlate. Net acid consumptions for bottle roll tests were 10.6 to $36.2 \mathrm{~kg} / \mathrm{t}$, compared to 4.1 to $55.9 \mathrm{~kg} / \mathrm{t}$ for column leach tests. 
Microscopic examination of the residues showed that a significant amount of native $\mathrm{Cu}$, as well as blue-green and dark black/blue grains that probably represent other $\mathrm{Cu}$ minerals, were left after leaching. The residue mineralogy was not examined further. Although I did not receive any formal report of a leach test focused on cyanide, the ICP and core log data that Newmont provided included data on cyanide-soluble Au and $\mathrm{Cu}$ based on 1-hour shaker tests for each core interval sampled. Based on these data, the $\mathrm{Au}$ in the supergene zone is typically 85 to $95 \%$ cyanide-soluble, compared to $\mathrm{Cu}$ cyanide solubility generally $<30 \%$. However, this may reflect the limited amount of reagent in the system rather than the insolubility of the $\mathrm{Cu}$ ore minerals.

\section{Materials, methods, and procedures}

\section{A. Sample prep}

Six samples of different supergene ore types were collected during summer 2016, with a focus on obtaining material of various $\mathrm{Cu}$ and $\mathrm{Au}$ grades and mineralogical characteristics and on covering a wide area of the deposit. Where available, the coarse rejects were taken as sample material; for the drill hole REB-00150, no coarse rejects were available and quarter-core was used instead. Each sample represents a single 20' $(6.06 \mathrm{~m})$ interval assay composite. Samples and location information are given in Table 4. For each sample, the core corresponding to the 20 ' composite interval was logged using a modified Anaconda-style method for mineralogical and geological context and textural information.

Sample prep and mineralogical work made use of the Freeport-McMoRan Inc.

Process Technology Center in Tucson. Each sample was stage-crushed to 100\% passing 
10 mesh $(2000 \mu \mathrm{m})$ using a roll crusher and dry test sieve. Half the crushed material was rotary-split into roughly 200 -g aliquots, with two additional $3 \mathrm{~g}$ splits of each sample for QEMSCAN and two additional $10 \mathrm{~g}$ splits for assaying. The remaining half of each sample was stage-crushed to -200 mesh $(75 \mu \mathrm{m})$ and divided into 200 -g splits, with one additional $10 \mathrm{~g}$ split for laser particle size analysis. No QEMSCAN splits were taken from the 200-mesh material.

Non-gold assay samples were pulverized to -200 microns and dissolved using 3acid microwave digestion with nitric, hydrochloric, and fluoboric acids, then analyzed with ICP-OES, including sulfur. Silicon was determined by HF digestion with AA finish. Sample REB-00133 had to be re-assayed for Au owing to consistent suspiciously high recoveries. Two 1-g samples of REB-00133 pulp remaining from the assay split were digested in aqua regia on a hot plate for 40 minutes and analyzed for Au on an Agilent 7700x ICP-MS.

\section{B. Mineralogical methods}

The mineralogical data gathered for head samples and leach residues in this study were collected by QEMSCAN (Quantitative Evaluation of Mineralogy by Scanning Electron Microscopy), a descendant of the QEM*SEM technique developed in Australia in the mid-1980s (Reid et al., 1984; Creelman et al., 1989). The QEMSCAN consists of a heavily automated scanning electron microscope and a computer database. The EDS spectrum and backscatter brightness of a sample for every pixel are compared to the specifications in a mineral database, and the pixel is assigned to the best-match mineral. Pirrie and Rollinson (2011) provide an overview of the technique. 
The QEMSCAN splits used in this study were converted to 27-mm epoxy mounts without graphite, held under vacuum, and hardened in an oven to dry before polishing down to $1-\mu \mathrm{m}$ grit. Surface smoothness was checked visually with an inverted microscope. The head sample mounts were carbon-coated and examined in a Zeiss Leo 1450-series QEMSCAN at a beam current of $5 \mathrm{nA}$ and accelerating voltage of $25 \mathrm{keV}$. Backscatter brightness was calibrated against quartz, pure copper, and pure gold standards before each analytical run. A standard mineral list was loaded and modified in order to import mineral backscatter and EDS peak intensities. The quantitative mineralogical evaluation was based on 5000 particle mineralogical analyses with a field spacing of $300 \mu \mathrm{m}$ and bulk mineralogical analyses (line scans) with $1800 \mu \mathrm{m}$ field size and 10-point spacing. Pixel size was $5 \mu \mathrm{m}$.

All samples except REB-00187 were resected and reexamined, with an additional resection for REB-00189. Follow-up analysis of iron oxides, jarosite, and alunite used a Quanta 400 SEM with an accelerating voltage of $20 \mathrm{keV}$. This revealed that the Fe oxide minerals (goethite, hematite, and jarosite) typically contain significant $\mathrm{Cu}$ and As (Table 5). The QEMSCAN iron oxide compositions were accordingly modified to include $2 / 3$ of the average $\mathrm{Cu}$ and As in each mineral. QEMSCAN assays recalculated on this basis reconciled with chemical assays to within $10 \%$ for $\mathrm{Cu}$ and As for all samples except REB-00189, which appeared to have a significant nugget effect. The remaining systematic overestimation of Fe by QEMSCAN for all samples was ascribed to gravitational settling of the relatively dense iron oxide minerals to what became the top of the epoxy mount, an inference supported by the lower QEMSCAN Fe content in resections than in the original measurements. 
Residue sample mounts were analyzed on an FEI Quanta 400 field emission QEMSCAN with line scans at $900 \mu \mathrm{m}$ field size and $4 \mu \mathrm{m}$ spacing. The mineral database and identification criteria were the same as for the head samples.

\section{Leaching methods}

Leach tests were conducted via bottle roll testing, using the conditions specified in Table 1. Both 10-mesh and 200-mesh splits of samples were tested, except for REB00189, of which there were not enough 200-mesh splits. All tests were carried out at 40\% solids and room temperature for 24 hours.

Each 200-g split was charged into a clean 1/2-gallon open glass bottle and partly filled with deionized water. The leaching and conditioning reagents were weighed or measured out in the amounts necessary for the concentrations specified in Table 1 and added to the bottles. After measurement of $\mathrm{pH}( \pm \mathrm{Eh})$, the bottles were rolled at $60 \mathrm{rpm}$. At 2 and 6 hours, the rolling was stopped and a roughly 10-mL sample of leach liquor was filtered and pipetted into a test tube. The $\mathrm{pH}( \pm \mathrm{Eh})$ was measured and reagent was titrated for cyanide, thiourea, and glycine (other acids were not titrated, but sulfuric acid concentration was inferred by $\mathrm{pH})$. Reagent concentration and $\mathrm{pH}$ were adjusted as necessary and the bottles were rolled again, except for sulfurous and methanesulfonic acids, for which no reagent was added. The detailed procedures for each bottle roll test are in Appendix A.

Kinetic samples were diluted 10x, 100x, and 1000x using standard solutions as nearly equivalent as possible to the leaching solution to avoid matrix-mismatch, and were then analyzed by AA on a single-lamp Perkin-Elmer atomic absorption 
spectrophotometer. For the thiourea leach tests, kinetic samples were also analyzed by ICP-MS on an Agilent 7700x along with standards diluted from stock solutions of $\mathrm{Cu}$ and Au after every 12 samples. The residues were filtered, rinsed in DI water, and dried, after which splits of all the 10-mesh residues were analyzed by QEMSCAN again using the same methods as for the head samples, detailed above.

\section{Results}

\section{A. Mineralogy and composition of head samples}

The results of the mineralogical and chemical analysis of head samples are shown in Table 6 and Figure 5. Major $\mathrm{Cu}$ ore minerals are native copper, cuprite, malachite, chrysocolla, and conichalcite, with locally significant $\mathrm{Cu}$ in jarosite and goethite. QEMSCAN field image scans indicate that liberation of the $\mathrm{Cu}$ minerals is nearly complete at -10 mesh size. Gangue mineralogy varies but is dominated by quartz, sericite, chlorite, alunite, smectite and kaolinite, K-feldspar, iron oxides, and jarosite. All Au discovered in the samples occurs as varieties of native gold, including auricupride and electrum. Most of the grains observed are locked in iron oxide grains, most commonly hematite, or quartz. Some hypogene minerals, including an unidentified Ag-sulfosalt, pyrite, and cinnabar, also survive in quartz grains, and some may contain additional $\mathrm{Au}$; however, their overall contribution to the samples' Au content is probably negligible owing to the rarity of such preserved grains. Only sample REB-00133 contained significant remaining sulfide material, but this was so fine-grained as to be visible only with SEM. 


\section{B. Leaching results}

The results of the bottle roll tests are shown in Table 7 and Figure 6a-b, with data given in Appendix B. Methanesulfonic and sulfuric acids yielded the best $\mathrm{Cu}$ recovery, with $\mathrm{Cu}$ extraction ranging from 30 to $90 \%$ for methanesulfonic and from 37 to $100 \%$ for sulfuric - results comparable to those obtained by Newmont's bottle roll tests with sulfuric acid at -200 mesh. Sulfurous acid was consistently in third place with 20 to $70 \%$ $\mathrm{Cu}$ recovery. Thiourea, glycine, and cyanide performed poorly and in no case recovered more than $52 \%$ of the $\mathrm{Cu}$. Their relative efficiency varied from sample to sample, though in 3 of 6 samples glycine was at least marginally more efficient than cyanide or thiourea. There was no consistent difference in $\mathrm{Cu}$ recovery with grain size for the 5 samples tested at -10 and -200 mesh.

The results for Au leaching indicate that glycine was the least effective lixiviant for Au by a wide margin, for all samples except REB-00189. However, the data regarding REB-00189 must be considered ambiguous since the discrepancies between QEMSCAN and assay results indicate that it is prone to the nugget effect for $\mathrm{Cu}$ distribution, and may also display the nugget effect for Au distribution. Only one split was tested for each lixiviant, and it is possible that by chance the split tested for cyanide contained anomalously little Au. If that were the case, even $100 \%$ recovery would lead to the false conclusion that cyanide leached Au less effectively than glycine in REB-00189. Thiourea was nearly as effective at cyanide at recovering $\mathrm{Au}$, consistently leaching > $60 \%$ regardless of head $\mathrm{Au}$ or $\mathrm{Cu}$ grade (Fig. 6).

The effects of grain size are noticeable for Au recovery, in contrast to $\mathrm{Cu}$. In the 5 samples tested at -10 and -200 mesh, recovery for the finer-grained split was equal to or 
better than recovery for the coarse split in 4 of 5 glycine tests, all 5 thiourea tests, and 4 of 5 cyanide tests. This is consistent with the observations of sub-10-micron-sized Aubearing grains locked in quartz or iron oxides in the 10-mesh mineralogy samples.

Gold recovery for several of the tests was higher than $100 \%$, particularly in samples REB-00187 and REB-00188. These are comparatively low in Au grade at 0.764 and $0.781 \mathrm{~g} / \mathrm{t}$ respectively; the four higher-grade samples $(0.96$ to $5.22 \mathrm{~g} / \mathrm{t}$ ) show recoveries much closer to $100 \%$ or below it. This suggests that statistics of small numbers may be responsible for the $150 \%$ recoveries in REB-00187 and REB-00188: a small error in absolute terms may be large enough relative to the gold grade to push apparent recovery well above $100 \%$. The nugget effect is another possible contributor, although there is no particular reason why it should affect both low-grade samples more than the higher-grade samples split by the same equipment.

Extrapolated reagent consumption varied for the four reagents (sulfuric acid, cyanide, thiourea, and glycine) that were added over the course of the bottle roll tests (Fig. 7). Methanesulfonic acid consumption was uncertain, as it was not titrated after 24 hours' leaching, so how much of the extrapolated $30 \mathrm{~kg} / \mathrm{t}$ would actually be consumed is unknown. Glycine consumption was highest at $10-20 \mathrm{~kg} / \mathrm{t}$, with thiourea more variable and generally lower. There was no particular correlation between $\mathrm{Cu}$ recovery at 24 hours and overall reagent consumption for any of the reagents. Consumption of cyanide was generally lowest at $<4 \mathrm{~kg} / \mathrm{t}$, but the expense of cyanide may offset this.

\section{Residue mineralogy}


QEMSCAN analysis of -10-mesh residues from each sample leached shows several consistent changes (Figure 8). Among the ore minerals, $50-70 \%$ of the conichalcite, $100 \%$ of the malachite, $80-100 \%$ of the chrysocolla, and $99 \%$ of the cuprite and native $\mathrm{Cu}$ have disappeared from the $\mathrm{H}_{2} \mathrm{SO}_{4}, \mathrm{H}_{2} \mathrm{SO}_{3}$, and MSA residues. Cyanide dissolved $<2 \%$ of the chrysocolla, none of the conichalcite, nearly all of the malachite, and $40-50 \%$ of the native $\mathrm{Cu}$ and cuprite. Thiourea dissolved $<30 \%$ of the conichalcite, $50-80 \%$ of the malachite, $50-60 \%$ of the chrysocolla, and $70-85 \%$ of the native $\mathrm{Cu}$ and cuprite. Glycine dissolved $<25 \%$ of the conichalcite, $12 \%$ of the cuprite, and none of the native $\mathrm{Cu}$. The amount of chrysocolla and malachite dissolved from the glycine residues was difficult to pinpoint. Glycine extracted $95 \%$ of the malachite and $60 \%$ of the chrysocolla from the two samples in which malachite and chrysocolla were $<0.1 \%$ each of the mineralogy, but only $10 \%$ of the chrysocolla and $60 \%$ of the malachite from the samples in which each was more abundant.

Table 8 shows the changes in gangue mineralogy, and the corresponding elemental assays are given in Appendix C. Few of the observed mineralogical changes were both consistent across most samples and statistically significant, but almost all residues showed a 5-10\% loss in alunite except for the samples leached with thiourea. Dolomite was removed from all samples in which it occurred, although the loss to glycine leaching was $<3 \%$. Iron oxide losses of $15-20 \%$ were consistent though not universal. Jarosite was lost from a few samples but mostly showed gains of $>20 \%$; there was no apparent pattern or rationale to the samples in which jarosite concentration increased. Muscovite and sericite showed gains of $20-30 \%$ in nearly all samples. 


\section{Discussion}

\section{A. Optimum method}

One clear result from this work is that none of the reagents tested will be able to recover both $\mathrm{Cu}$ and $\mathrm{Au}$ efficiently in one step. If only Au recovery is necessary, the best process is probably a single-step leach with either cyanide or thiourea, accepting a high reagent consumption in either case. If economic considerations dictate the recovery of both metals, the best option is a combined process that recovers $\mathrm{Cu}$ first, then $\mathrm{Au}$, to minimize base metal interference with the gold-recovering reagent. Preliminary testing of a two-stage leaching process involving a 1-hour leach with $10 \mathrm{~g} / \mathrm{L}$ sulfuric acid followed by a 24-hour leach with $10 \mathrm{~g} / \mathrm{L}$ thiourea indicates that the sulfuric acid leach effectively removes $70 \%$ of the $\mathrm{Cu}$ from the chrysocolla-bearing sample, and $40 \%$ of the $\mathrm{Cu}$ from the conichalcite-bearing sample. The 24-hour Au extraction ranged from $80-100 \%$.

\section{B. Inferred reasons for lixiviant performance}

0) Mineralogy

Copper mineralogy clearly affects recovery. Conichalcite appears to be the most problematic mineral for all lixiviants, as seen by comparing the results of samples REB00187 with REB-00150 and REB-00188. All three contain slightly less than $0.10 \% \mathrm{Cu}$ (Table 4), but $\mathrm{Cu}$ recoveries for REB-00150 and REB-00188 were never $>42 \%$. The principal $\mathrm{Cu}$ mineral in both REB-00150 and REB-00188 is conichalcite. By contrast, REB-00187, which contains appreciable chrysocolla as well as conichalcite, yielded > $60 \%$ recovery in sulfuric, sulfurous, and methanesulfonic acids. Comparing REB-00133 (conichalcite) with REB-00185 (chrysocolla), two samples with roughly $0.4-0.5 \% \mathrm{Cu}$, 
gives a similar result: the three acids recovered $>50 \%$ of the $\mathrm{Cu}$ from REB-00185, but only two splits from REB-00133 showed comparable extraction. Although chrysocolla is

generally considered the least soluble of the common $\mathrm{Cu}$ minerals in cyanide (Hedley and Tabachnick, 1958) and glycine (Tanda et al., 2017), both cyanide and glycine, as well as thiourea, recovered more $\mathrm{Cu}$ from the chrysocolla-rich samples than they did from the conichalcite, suggesting that conichalcite is even less soluble than chrysocolla in all three.

The effects of cuprite and native $\mathrm{Cu}$, which are abundant only in REB-00189, are unclear. The nugget effect observed in the QEMSCAN and assay results (Fig. 9) means that it is uncertain exactly how much $\mathrm{Cu}$ was present in each of the splits taken although the 200-g bottle roll splits could be expected to have a more uniform $\mathrm{Cu}$ concentration than the 30-g assay splits or the 3-g mineralogy splits. Assuming that all the splits used in bottle roll testing had comparable $\mathrm{Cu}$ concentrations, cuprite and native $\mathrm{Cu}$ dissolved best in sulfuric and methanesulfonic acids. Sulfurous acid and glycine both extracted $50-60 \%$ of the $\mathrm{Cu}$, whereas cyanide and thiourea extracted $<25 \%$.

\section{1) Sulfuric acid}

That sulfuric acid is one of the best reagents for recovering $\mathrm{Cu}$ from oxides is no surprise. Its performance in this study is consistent with the results of other studies as well as general industry observations, although there are no existing data on conichalcite dissolution in sulfuric acid. The ore mineralogical changes shown in Figure 8 are consistent with the recoveries in Figure 6A, indicating that only Cu-bearing Fe oxides and (to a lesser extent) conichalcite resist dissolution in sulfuric acid. 
The only surprise is the high recovery in REB-00189, since copper and cuprite are the two supergene $\mathrm{Cu}$ minerals least easily dissolved in sulfuric acid, even with an oxidant. Moreover, the samples with native $\mathrm{Cu}$ had the lowest recoveries from Newmont's bottle roll tests, described above, at 31 to $64 \%$ recovery. The Newmont report does not mention whether $\mathrm{Fe}^{3+}$ was also added, which would be standard procedure. If no oxidant was added during the Newmont bottle roll testing, the recoveries of native $\mathrm{Cu}$ would be approximately in line with expectations, and it would stand to reason that the tests with an oxidant yielded more $\mathrm{Cu}$. Another possibility is that the split of REB-00189 tested with sulfuric acid had a higher concentration of $\mathrm{Cu}$ than the others, which is plausible given the observed nugget effect with $\mathrm{Cu}$ in that sample (see Fig. 9). Which is correct is a subject for further testing.

The price of sulfuric acid is approximately $\$ 250$ per metric ton, or $25 \phi / \mathrm{kg}$. At these prices, the cost of the leaching reagent for one ton of material would range from $\$ 3.75$ (lowest reagent consumption calculated in this study) to $\$ 5.50$ (highest reagent consumption). This is only a fraction of the recoverable $\mathrm{Cu}$ value contained in a ton of rock with average grade, so sulfuric acid is an economic reagent at current prices.

\section{2) Sulfurous acid}

According to the sparse literature on the subject, sulfurous acid is supposed to be at least as effective as sulfuric acid at dissolving complex copper oxides (Youzbashi and Dixit, 1993; Gbor et al., 2002). Previous work suggests that the dissolution caused by the acid proton is enhanced by second-order dissolution caused by the sulfite ion (Youzbashi 
and Dixit, 1993). Contrarily, the sulfate ion in $\mathrm{H}_{2} \mathrm{SO}_{4}$ inhibits dissolution rather than augmenting it, limiting $\mathrm{Cu}$ recovery by sulfuric acid. Or so the theory goes.

In nearly every sample tested in this study, sulfurous acid recovered less $\mathrm{Cu}$ than sulfuric and methanesulfonic acids extracted at the same mesh size (Fig. 6a). The two exceptions, REB-00185 and REB-00187, were both dominated by chrysocolla; sulfurous acid compared poorly to sulfuric and methanesulfonic in the samples with conichalcite, cuprite, and native $\mathrm{Cu}$. This is partly consistent with Figure 8, which shows that the $\mathrm{H}_{2} \mathrm{SO}_{3}$ residues contain significantly more remaining conichalcite than the $\mathrm{H}_{2} \mathrm{SO}_{4}$ residues. However, the QEMSCAN data in Figure 8 indicate that sulfurous acid dissolved $\mathrm{Cu}$ from native $\mathrm{Cu}$ and cuprite as effectively as $\mathrm{H}_{2} \mathrm{SO}_{4}$, which does not agree with the recoveries calculated. It is also inconsistent with the results reported by Gbor et al. (2002), who found $\mathrm{H}_{2} \mathrm{SO}_{3}$ a more effective lixiviant than $\mathrm{H}_{2} \mathrm{SO}_{4}$ in dissolving $\mathrm{Co}$, $\mathrm{Ni}$, and Fe from old smelter slags. One possible reason for this is, again, the nugget effect: the split of REB-00189 leached with sulfurous acid may contain less $\mathrm{Cu}$ than the split leached by sulfuric. This would account for the difference in recovery and the similarity in mineral dissolution, although the nugget effect that caused pronounced variation in the analyzed $\mathrm{Cu}$ content of 3-g mineralogy splits should not cause much difference in the $\mathrm{Cu}$ content of 200-g bottle roll splits.

Differences in the mineralogy of the materials tested is likely to be one factor in the discrepancy between these results and the literature; Gbor et al.'s (2002) samples were slags containing $\mathrm{Ni}, \mathrm{Co}$, and $\mathrm{Fe}$. Their mineralogy is not reported but their chemical analyses indicated that the dominant minerals were either native metals or simple oxides, with only minor sulfide content. Another factor is the lack of $\mathrm{pH}$ control in the present 
study. Gbor et al. (2002) maintained $\mathrm{pH}$ at 2 over the course of their study, whereas in four of the tests in the present study (the -200 mesh split of REB-00187, both splits of REB-00188, and REB-00189) the pH rose above 2 and was not corrected back to 2 . This likely caused diminished Cu recovery, as Youzbashi and Dixit (1993) demonstrated for cuprite. Their $55 \% \mathrm{Cu}$ extraction for 30 minutes of cuprite leaching at a $\mathrm{pH}$ of 2 is somewhat lower than the $62 \%$ for REB- 00189 , where the $\mathrm{pH}$ had reached 2.12 by the 2 hour kinetic check and 2.95 by the end of the 24 -hour test.

One notable feature of the sulfurous acid leaching kinetic charts (Fig. 10) is that $\mathrm{Cu}$ in solution reaches a maximum at 6 hours and decreases or remains steady over time. Youzbashi and Dixit (1993) also observed this in their tests with cuprite at $\mathrm{pH}>2$ and Ahmed et al. (2000) found a substantial decrease over time in the recovery of $\mathrm{Cu}$ from a sulfide phase in slag leached with sulfurous acid. Both attributed it to re-precipitation of some of the $\mathrm{Cu}$ after its reduction by $\mathrm{Fe}^{2+}$, identifying the precipitated phases as Chevreul's salts $\left(\mathrm{Cu}\left(\mathrm{SO}_{3}\right)_{2}\right)$. In the case of the slag minerals, which were sulfides, surface passivation by a sulfur layer was also blamed (Ahmed et al., 2000). The decrease in $\mathrm{Cu}$ concentration in solution over time in this study is only observed in 3 of 11 tests and is slight by comparison with the drop of 20 percentage points observed in the cuprite. The smallness of the decrease, where it is present at all, is likely due to the addition of $\mathrm{Fe}^{3+}$ and to leaving the bottles open to air, neither of which characterized the other two studies cited.

Prices for sulfurous acid were only available at retail websites; GSF Chemicals quotes a price of $\$ 213$ for $10 \mathrm{~L}$ of $6 \%$ sulfurous acid. This translates into a price of $\$ 355$ for $1 \mathrm{~kg}$ of pure $\mathrm{H}_{2} \mathrm{SO}_{3}$, and a cost (at $14 \mathrm{~kg} / \mathrm{t}$ acid consumption) of $\$ 4,970$ per ton of ore- 
bearing material processed. At these costs, and with no Au recovery, sulfurous acid is too expensive to be economic, by several orders of magnitude.

3) Cyanide

Figure 6 a clearly shows that cyanide did not recover more than $25 \%$ of the $\mathrm{Cu}$ in any sample and performed particularly poorly in samples containing conichalcite, which is consistent with Figure 8. This is the same pattern observed for the other lixiviants, which also failed to recover conichalcite effectively. Gold recovery by cyanide was within error of $100 \%$ except in sample REB-00189, where it reached $50 \%$ in the first six hours and rose no higher. This may be due to $\mathrm{Cu}$ competing with $\mathrm{Au}$ for cyanide, which (at $1000 \mathrm{ppm}$ ) would have been in short supply compared to the amount of $\mathrm{Cu}$ in the sample, let alone $\mathrm{Au}$; however, this does not seem to have been a factor in the other $\mathrm{Cu}$ rich samples. Another possibility is that some of the Au entered solution and then cemented onto the native $\mathrm{Cu}$ in the sample, a phenomenon described by Tran et al. (1997). In their study, Tran et al. (1997) found that 1000 ppm cyanide was sufficient to redissolve all the native $\mathrm{Cu}$ and with it the cemented $\mathrm{Au}$, so the native $\mathrm{Cu}$ did not affect 24-hour recovery. The $\mathrm{Cu}$ grade of their sample was not stated, but it dissolved $500 \mathrm{mg} / \mathrm{L}$ into solution, whereas the kinetic samples in REB-00189 contained $642 \mathrm{mg} / \mathrm{L} \mathrm{Cu}$ at 2 hours and $1337 \mathrm{mg} / \mathrm{L} \mathrm{Cu}$ by 24 hours. Thus, it is possible that some of the $\mathrm{Cu}$, and the $\mathrm{Au}$ cemented onto it, did not dissolve owing to lack of cyanide.

The cyanide recovery of $\mathrm{Cu}$ in this study is consistent with the results of Newmont's leach tests, which show that $<25 \%$ of the $\mathrm{Cu}$ is generally soluble in cyanide. This is in spite of the fact that all of the $\mathrm{Cu}$ ore minerals except chrysocolla are supposed 
to be cyanide-soluble (Hedley and Tabachnick, 1958; Sceresini, 2005). The solubility of conichalcite in cyanide is unknown.

One explanation is that $1000 \mathrm{ppm}$ cyanide is not enough to dissolve all of the $\mathrm{Cu}$ present in the Mike samples, and the limitation is the amount of available reagent rather than the solubility of the minerals. This is likely the case for REB-00189, from which cyanide recovered $24 \%$ of the $\mathrm{Cu}$ or about $400 \mathrm{mg} \mathrm{Cu}$. This is the maximum possible recovery with $1000 \mathrm{ppm}$ cyanide, with $\mathrm{Cu}$ speciating as a $\mathrm{CuCN}^{0}$ complex, and is consistent with Figure 8 , which shows that $\mathrm{NaCN}$ was capable of at least partially dissolving all the major $\mathrm{Cu}$ minerals except for chrysocolla and the $\mathrm{Cu}$-bearing Fe oxides. However, in all the other samples the amount of $\mathrm{Cu}$ in solution is less than the maximum possible (e.g., $100 \%$ recovery from $0.48 \% \mathrm{Cu}$ would put about $960 \mathrm{ppm} \mathrm{Cu}$ in solution, more than twice the 24-hour recovery for both splits of REB-00185). This probably reflects the known insolubility of chrysocolla in cyanide for REB-00185 and REB-00187, which is supported by the lack of evident dissolution of chrysocolla in Figure 8. The lack of recovery in REB-00133, as well as in the other samples that contain conichalcite, probably indicates that conichalcite is just as insoluble in cyanide.

Kinetic charts (Fig. 10) show that the leaching kinetics of $\mathrm{Cu}$ in cyanide are considerably slower than for any of the acids, which is consistent with theoretical predictions and previous observations (e.g. Lower and Booth, 1965). The leaching of $\mathrm{Au}$ also appears to proceed slowly in several of the samples and increases appreciably between 6 and 24 hours, indicating that recovery might improve with a longer leaching time (Fig. 10). 
A study by Breuer et al. (2005) of leaching gold mixed with chalcocite, cuprite, tenorite, and covellite by cyanide solutions shows that they extracted about $8 \mathrm{mM} \mathrm{Cu}$ in 24 hours with a $\mathrm{CN}$ concentration of $40 \mathrm{mM}$, and $6 \mathrm{mM} \mathrm{Cu}$ in 24 hours with $15 \mathrm{mM} \mathrm{CN}$. These recoveries are significantly lower than the ones obtained in this study, which produced leach liquors ranging from 770 to $20500 \mathrm{mM}$ for different samples. However, recovery of $\mathrm{Cu}$ by $1000 \mathrm{ppm}$ cyanide solution reached $100 \%$ in 12 hours in a study by Tran et al. (1997) on an unspecified Cu mineral. This is well above the recovery obtained here for any of the samples, but is consistent with other studies showing nearly $100 \%$ recovery of $\mathrm{Cu}$ by cyanide (e.g. Lower and Booth, 1965; Breuer et al., 2005). However, in each of the studies with near-perfect recovery, cyanide was present in at least a 3:1 molar ratio with $\mathrm{Cu}$, significantly higher than in this study. Although these results are not conclusive, they suggest that the poor recovery of $\mathrm{Cu}$ by cyanide in the Mike ores could be remedied by using higher reagent concentrations, although this would significantly increase costs.

It proved nearly impossible to find current price data for sodium cyanide at industrial grades and quantities. Records from the early 2000s suggested that the $\mathrm{NaCN}$ price was then around $\$ 0.50 / \mathrm{lb}$. Using this as a baseline and assuming a current price of $\$ 2 / \mathrm{kg} \mathrm{NaCN}$ today, processing one ton of Mike material of average grade would cost between $\$ 2$ and $\$ 8$. This is easily economic given the Au recovery, since the average Au grade at Mike translates into a gold value per ton of about $\$ 30$, not counting the value of any $\mathrm{Cu}$ recovered.

4) Thiourea 
Of all the reagents examined, thiourea performed the worst in extracting $\mathrm{Cu}$, recovering $<10 \%$ of the $\mathrm{Cu}$ from all samples except REB-00187 (Fig. 6a). However, recovery for the 200-mesh split of REB-00187 was $23 \%$, indicating that thiourea extracted more $\mathrm{Cu}$ from this sample than from any of the others. There is no apparent reason for this, since REB-00187 contains $\mathrm{Cu}$ as a mix of chrysocolla and conichalcite, and its gangue mineralogy is the least reactive among all the samples with $75 \%$ quartz (Fig. 5). If thiourea were exceptionally effective at leaching chrysocolla, the recovery in REB-00185 should be good; Figure 6a shows that it is $<10 \%$, and Figure 8 demonstrates that in several samples the thiourea leached little or none of the chrysocolla present. It may be that a gangue mineral in REB-00185 interfered with the thiourea-copper reactions, but this is a subject for further investigation. The ICP results show that thiourea is comparable to cyanide as a lixiviant for $\mathrm{Au}$ and performs well irrespective of $\mathrm{Cu}$ grade or mineralogy (Fig. 6b).

The poor performance of thiourea in recovering $\mathrm{Cu}$, virtually irrespective of ore mineralogy, is consistent with the results obtained in other studies, most of which found thiourea an ineffective lixiviant for $\mathrm{Cu}$ without pre-treatment. McInnes et al. (1989) achieved an extraction rate of $66.6 \% \mathrm{Au}$ and $53.5 \% \mathrm{Cu}$ by leaching with thiourea and $\mathrm{Fe}^{3+}$ after 4-24 hours' leaching with sulfuric acid. However, without a sulfuric acid preleach, the Cu recovery was only about $20 \%$. Lacoste-Bouchet et al. (1998) compared the results of cyanide and thiourea leaching of an ore sample of $0.4 \% \mathrm{Cu}$ and $5.6 \mathrm{~g} / \mathrm{t} \mathrm{Au}$, whose mineralogy consisted of quartz, pyrite, chalcopyrite, and trace bornite, sphalerite, covellite, and galena. Their results showed that thiourea could extract from 53.9 to $83.0 \%$ of the Au in samples depending on the reagent concentrations and pretreatment style. The 
best results came from leaching with thiourea after a sulfuric acid pre-leach step, making their observations similar to those obtained by McInnes et al. (1989). Chen et al. (1980) found very low $\mathrm{Cu}$ recovery for thiourea leaching of $\mathrm{Au}-\mathrm{Ag}-\mathrm{Cu}$ ores of unspecified composition.

No prices for bulk purchase of thiourea were available, so VWR's quoted price of $\$ 389$ per $10 \mathrm{~kg}$ should be taken with some caution. At thiourea consumptions ranging from 4 to $17 \mathrm{~kg} / \mathrm{t}$, this represents a price of $\$ 152$ to $\$ 646$ per ton of average Mike rock. Although the price of thiourea in bulk is probably much lower than VWR's quote for the retail quantity, thiourea would be uneconomic if it costs more than approximately $\$ 3-\$ 4$ per kg in bulk, given the relatively high reagent consumption observed during the leach tests.

\section{5) Glycine}

Like the other lixiviants tested, recovery data show that glycine works best at dissolving malachite, cuprite, and native $\mathrm{Cu}$ and worst at dissolving conichalcite. In the conichalcite-dominated samples, $\mathrm{Cu}$ recovery by glycine is comparable to recovery by cyanide and thiourea (Fig. 6a). Glycine Cu recovery from chrysocolla is better than for cyanide or thiourea but is still quite low (Fig. 8). Given that glycine, at $0.5 \mathrm{M}$, was $25 \mathrm{x}$ more concentrated than the cyanide and $4.5 \mathrm{x}$ more concentrated than the thiourea tested, these results are not impressive. The only significant improvement in $\mathrm{Cu}$ recovery by glycine was the extraction of $51 \%$ of the $\mathrm{Cu}$ from the cuprite and native $\mathrm{Cu}$ in REB00189, a much better result than either thiourea or cyanide yielded but still far below the recoveries achieved by any of the three acids tested. This is inconsistent with the 
QEMSCAN residue analysis in Fig. 8, which is being sent for resection and reanalysis. The 51\% extraction was also less than Oraby and Eksteen (2014) found in glycine leaching of a $\mathrm{Cu}-\mathrm{Au}$ concentrate, in which glycine extracted $100 \%$ of the $\mathrm{Cu}$ from cuprite and native $\mathrm{Cu}$ in 48 hours. Extending the leach time to 48 hours is unlikely to produce similar improvement for the Mike samples, which show $\mathrm{Cu}$ recovery reaching a plateau after six hours of leaching (Fig. 10).

Tanda et al. (2017) mention that acceptable $\mathrm{Cu}$ recovery (83-95\%) from malachite, azurite, and cuprite was possible with a 4:1 glycine-to-Cu ratio, and recovery was optimal (>94\%) at an 8:1 ratio, both on a molar basis. The molar glycine:Cu ratio in this study varied with sample grade; for REB-00189, the highest-grade sample, it was 4.9:1 and was higher in samples with less $\mathrm{Cu}$. This should have been enough glycine to achieve more than the $51 \% \mathrm{Cu}$ recovery observed in REB-00189, to say nothing of the other samples. The principal conclusion from this is that the major ore minerals are insoluble in glycine. This is known to be the case for chrysocolla (Tanda et al., 2017), and is plausible for conichalcite given its evident resistance to dissolving in anything, but native $\mathrm{Cu}$ and cuprite are both supposed to be 95 to $100 \%$ glycine-soluble. However, virtually all of the published glycine tests were performed on crushed and ground mineral specimens rather than whole ore, as was done here. This suggests that gangue interferences are a significant detriment to $\mathrm{Cu}$ recovery by glycine from nominally soluble ore minerals.

Adsorption is a possible mechanism for gangue interference with glycine leaching, as the dominantly silicate gangue minerals have strongly positive zeta potentials at $\mathrm{pH}$ of 11 and would attract the negative end of the glycine zwitterion. However, 
titration of kinetic samples showed that appreciable glycine was always present in the leach solutions, which would not be the case if most of it were adsorbed on gangue. Oraby and Eksteen (2014) noted that the number of Cu-bearing boundary phases observed in QEMSCAN increased from about 0.35 to about $0.62 \%$ after 96 hours of single-stage glycine leaching. They attributed this to adsorption of $\mathrm{Cu}$ on clays or diffusion of $\mathrm{Cu}$ into silicates during the leaching tests. However, this is not consistent with their observation of continuous increase in the $\mathrm{Cu}$ in solution during the test, since the diffusing or adsorbing $\mathrm{Cu}$ would have had to come from solution. The mass percentages were based on QEMSCAN figures, for which there is likely a significant error. They also do not take into account the tendency for the mechanical abrasion during bottle roll testing to decrease the average grain size of a sample and thereby to increase the number of boundary phases, which may or may not be part of the reason for the observed increase in $\mathrm{Cu}$-bearing boundary phases.

Glycine also performed significantly worse than cyanide or thiourea at recovering $\mathrm{Au}$ in most samples (Fig. 6b). Gold recovery by glycine exceeded recovery by cyanide only in REB-00189, which is also the only sample in which the $\mathrm{Cu}$ apparently used up all of the cyanide. Glycine also outperformed cyanide in the -10-mesh split of REB-00188, but recovered less Au than cyanide extracted from the -200-mesh split of the same sample. This may signify imperfect liberation of the Au in REB-00188 at -10 mesh, although it would be strange for this problem to occur in only one split of the 36 tested.

All of the kinetic plots for glycine (Fig. 10) show that Au recovery continues to improve from 6 to 24 hours. This suggests that glycine may be able to extract more $\mathrm{Au}$ than Figure $6 \mathrm{~b}$ shows in a longer time. This is consistent with studies by Oraby and 
Eksteen (2015), who found that Au extraction continued up to the end of their 170-hour test. At 24 hours, their $0.5 \mathrm{M}$ glycine solution (1\% peroxide) had leached $<1 \mathrm{mg} / \mathrm{L}$ of $\mathrm{Au}$, which is about the same as the 24-hour extraction rate in this study.

Spectrum Laboratory Products quotes a price of $\$ 1204$ for $50 \mathrm{~kg}$ of glycine, which translates to $\$ 24 / \mathrm{kg}$. Although this is probably the retail rather than the bulk rate, at a glycine consumption of 10 to $22 \mathrm{~kg} / \mathrm{t}$ it would mean a cost of $\$ 241$ to $\$ 530$ for leaching one ton of average Mike material. Even if recovery from glycine leaching were much higher than the results of this study indicate, this would render glycine uneconomic. Its cost would have to be approximately $\$ 2-\$ 3$ per $\mathrm{kg}$ in order to be economic.

6) Methanesulfonic acid

The results of leaching with methanesulfonic acid show patterns largely similar to the performance of sulfuric and sulfurous acids, and recovery of $\mathrm{Cu}$ from conichalcitedominated samples by methanesulfonic acid is about the same as by sulfuric acid. There are two noticeable differences: firstly, four of five samples tested at different grain sizes show better recovery for the finer grind, and secondly, methanesulfonic acid recovers more $\mathrm{Cu}$ from the chrysocolla-bearing samples than the other acids. There is no obvious explanation for why grain size should matter for methanesulfonic but not for sulfuric or sulfurous acids, and that result is probably a statistical fluke. The greater recovery from chrysocolla will have to be substantiated by continuing work and the reasons for it ascertained with a more thorough study of methanesulfonic acid, since Figure 8 shows 
that there is no significant difference in the amount of chrysocolla dissolved by sulfuric and methanesulfonic acids.

The kinetic charts (Fig. 10a) for methanesulfonic acid show the rapid kinetics that Feng et al. (2015) observed for malachite, with rates similar to the dissolution rates of sulfuric and sulfurous acids. One difference is that in 7 of 11 samples tested, recovery was highest between 2 and 6 hours and decreased slightly from the peak by 24 hours. This occurs in samples of all ore minerals tested and may reflect re-precipitation or adsorption of $\mathrm{Cu}$ from solution, possibly caused or exacerbated by not adding more reagent during kinetic checks.

Prices for methanesulfonic acid found online range from $\$ 18 / \mathrm{kg}$ to $\$ 31 / \mathrm{kg}$, the latter representing retail value. Even at the lower price, the cost for leaching one ton of material is approximately $\$ 540$, far too high for MSA to be economic.

\section{Mineralogical factors in reagent consumption}

Reagent consumption is an important factor in choosing a lixiviant for any system. Glycine consumption was the highest and most variable among all lixiviants, reaching the equivalent of $22 \mathrm{~kg} / \mathrm{t}$ in REB-00185 with $>10 \mathrm{~kg}$ consumed in all samples. There are no data in the literature to indicate whether this glycine consumption is consistent with the results of existing tests, such as those by Oraby and Eksteen (2014, 2015), Eksteen and Oraby (2015), and Tanda et al. (2017), none of which say how much glycine was consumed in their experiments. The values were almost certainly high given the $4: 1$ to $8: 1$ glycine:Cu ratio recommended for effective leaching. 
Thiourea, at 5 to $17 \mathrm{~kg} / \mathrm{t}$, is consistent with reported levels of consumption. Recorded thiourea consumption in the literature ranges from 4 to $47 \mathrm{~kg} / \mathrm{t}$ and has long been one of the main obstacles to widespread industrial application (Hiskey, 1981; Aylmore, 2005). This can be decreased by various pre-treatment steps; Lacoste-Bouchet et al. (1998) found that acid washing of a $\mathrm{Cu}-\mathrm{Au}$ ore before thiourea leaching reduced thiourea consumption slightly and increased Au recovery from 65 to $75 \%$. Their ore was a mix of sulfides dominated by chalcopyrite, but it is likely that a similar acid preleaching would benefit recovery from the ores at Mike.

Sulfuric acid consumption does not correlate with $\mathrm{Cu}$ recovery but is relatively stable around an affordable $14 \mathrm{~kg} / \mathrm{t}$ for most of the samples. This is consistent with the results of Newmont's bottle roll sulfuric acid tests, which indicated a consumption of 15$17 \mathrm{~kg} / \mathrm{t}$ for most samples, with a few exceptions (Table 3). The exception is REB-00188, where acid consumption reaches $20.4 \mathrm{~kg} / \mathrm{t}$. This is the only sample to contain significant carbonates, and the $1.2 \%$ dolomite in it (Table 6) precisely accounts for the extra $6.4 \mathrm{~kg} / \mathrm{t}$ of sulfuric acid. This is borne out by the absence of dolomite from the residue sample of REB-00188 after sulfuric acid leaching. The dolomite's effects are also evident in the $\mathrm{pH}$ increase observed in leaching sample REB-00188 with sulfurous and methanesulfonic acids; it appears to have had no effect on thiourea, cyanide, or glycine consumption. Cyanide consumption is generally $<1 \mathrm{~kg} / \mathrm{t}$, the exceptions being REB-00185 and REB00189 with 2 and $4 \mathrm{~kg} / \mathrm{t}$ cyanide consumption respectively. The $0.66 \%$ of chrysocolla in REB-00185 (Table 6) alone can consume 1.8 to $7.3 \mathrm{~kg} / \mathrm{t}$ of cyanide if it dissolves completely, depending on whether it speciates as $\mathrm{CuCN}$ or $\mathrm{Cu}(\mathrm{CN})_{4}$, so it probably explains the slight increase in cyanide consumption compared to the non-chrysocolla- 
bearing samples. In REB-00189, native $\mathrm{Cu}$ and cuprite appear to have consumed all the cyanide available in solution, as discussed above. These minerals may also be responsible for the high consumption of thiourea in the same sample.

\section{Mineralogical changes}

Some of the mineralogical transformations observed, such as the loss of dolomite, are expected from the chemistry of the leach solution and the known solubilities of minerals and are supported by comparison with the leaching data (e.g., the higher acid consumption the dolomite-bearing REB-00188).

The increase in jarosite and muscovite is harder to explain. Some of it may be due to the decrease in overall sample mass during leaching, which would have resulted in a net increase in the proportion of the insoluble minerals without any change to their absolute quantity. However, observed volume loss for the residues is $<5 \%$, so any change it induced in the proportions of the minerals is probably within the bounds of QEMSCAN error. The apparent changes in Al concentration from head to residues offer a first-order approximation of the expected changes related to volume loss. Aluminum is effectively insoluble under leaching conditions, so any changes in its assay or QEMSCAN concentrations probably represent the error of the technique. The chemical assays show that the difference between head and residue Al concentrations is $<5 \%$. Any elemental change of $>5 \%$ may therefore be considered a genuine effect.

The high-jarosite ( $>0.5 \%$ in head) samples show increases of more than $30 \%$ in jarosite content except for REB-00133, according to QEMSCAN. This might indicate jarosite precipitation, which would be consistent with the chemistry of leaching (e.g. 
Davis and Ashenberg, 1989). However, it is not matched by a consistent increase in S and $\mathrm{K}$ in the element assays; rather, $\mathrm{K}$ increases in nearly all samples irrespective of reagent and $\mathrm{S}$ shows a smaller increase or remains constant. Sulfur was present in most of the reagents used (all acids, thiourea, and ferric sulfate), so an increase in S content in the residues is not surprising and jarosite is a likely candidate for accommodating it. But the lack of consistency, and of magnitude compared with the $\mathrm{K}$ increase, suggests that at least some of the jarosite increase is probably a factor of QEMSCAN error and/or abnormally low jarosite content in the mineralogy splits from head samples. But this cannot explain all of the jarosite, which should correlate perfectly with increases in S and Fe if it were purely an artifact of QEMSCAN. This is not observed, and the most likely conclusion is that some of the increase in jarosite is genuine.

The apparent loss in Fe oxides is not consistent with Figure 8, which shows no significant change in the $\mathrm{Cu}$-bearing hematite and goethite with leaching in any sample or with any reagent. It is implausible that $\mathrm{Fe}$ oxide species with only a few percent $\mathrm{Cu}$ are much less soluble than their stoichiometric counterparts and the most likely explanation is QEMSCAN error. The same is true of the apparent gains in muscovite or sericite, which generally forms by acid degradation of K-feldspar. Table 8 shows that there is no consistent loss of K-feldspar in the QEMSCAN residues, and a few samples show slight gains, virtually eliminating the possibility that K-feldspar converted to muscovite during leaching.

Apart from the dissolution of $\mathrm{Cu}$ minerals, no other mineralogical changes recorded by QEMSCAN appear to be consistent and significant (i.e., > 5\% gain or loss from the head sample). The one unresolved issue is the apparent increase in $\mathrm{K}$, which 
(unlike S) was not present in any of the reagents used and whose concentration in the samples was presumably fixed. Contamination is a possibility, but the presence and magnitude of the $\mathrm{K}$ increase is too inconsistent for it to be likely.

\section{E. Reconciliation and sources of error}

Because the residues were not analyzed for $\mathrm{Au}$, circuit balance or reconciliation used only the $\mathrm{Cu}$ assays. Accountability for each -10 mesh leach test was calculated as grams of $\mathrm{Cu}$ in the solution at 24 hours plus grams of $\mathrm{Cu}$ left in the residue, divided by grams of $\mathrm{Cu}$ in the head and expressed as a percentage (Table 7). Overall, the accountability for all samples is $100 \pm 20 \%$ and for $87 \%$ of the samples is $100 \pm 15 \%$. Average accountability percentage was $99.7 \%$, indicating that the errors follow a random rather than a systematic distribution. There does not appear to be a consistent pattern to the higher-error samples, which represent a variety of reagents, minerals, and grades.

Some potential error is associated with each step in the analytical and experimental process. A significant amount of it is probably present in QEMSCAN, although there is very little literature on QEMSCAN error. Figure 9 compares the results of chemical assays with the compositions derived from QEMSCAN mineralogy data for head samples. For most samples, the elements measured show reasonably good correspondence by both methods. The exception is Fe, which QEMSCAN consistently overestimates relative to the chemical assay methods. The errors associated with other elements $(\mathrm{K}, \mathrm{Al}, \mathrm{S}, \mathrm{As}, \mathrm{Cu})$ look more like random error, with the QEMSCAN analyses sometimes yielding higher and sometimes lower concentrations than the chemical assays. Potassium and aluminum, like Fe, consistently show a significant disparity between 
QEMSCAN and chemical assay values, although the $\mathrm{Cu}$ measurement in REB-00189 shows the largest absolute spread.

There is not much in the literature about the expected errors in a QEMSCAN or automated mineralogical analysis. Mermillod-Blondin et al. (2016) compute the overall error of MLA (Mineral Liberation Analyzer) analysis as $\pm 20 \%$ for mineral phases making up $10 \%$ or more of the sample, which in their case was a series of galena blends with other sulfides. Less abundant minerals have higher relative measurement error. It should be noted that with the exception of three data points, all relative standard deviations for mineral phases making up more than $10 \%$ of the sample were below $10 \%$, so their error estimate of $20 \%$ may err on the high side.

Some sources of error can be inferred, if not quantified, based on the procedures and principles of QEMSCAN and the sample preparation procedures. One well-known factor is the tendency of dense minerals to settle to the bottom of the mold while the epoxy hardens; then the bottom of the mold becomes the top of the mount, and it has a disproportionately high concentration of dense minerals. This probably explains the consistent overestimation of Fe concentration by QEMSCAN, and it gains support from the observation that the largest disparity between QEMSCAN and chemical Fe content is found in the samples with the highest iron oxide content and the disparity decreases with decreasing iron oxide percentage. Density settling may also have been a factor in the large spread of $\mathrm{Cu}$ grade analyzed in REB-00189, which is the only sample in which $\mathrm{Cu}$ occurs mainly as the dense native metal.

The QEMSCAN method also leaves significant ambiguity in the identification and differentiation of certain groups of minerals, particularly the different iron oxides and 
the hydrous silicates (e.g., Ayling et al., 2012). Although the consequences of misidentification are not likely to be serious on the scale of typical processing circuits (with a few exceptions), calculating chemistry from the wrong mineral composition could easily contribute to QEMSCAN error. Likewise, the QEMSCAN cannot account for solid solution and other departures from stoichiometry except by clumsy hand corrections as described above. This is likely to lead to errors in calculating the compositions of minerals in solid solution. This may explain the overestimation of $\mathrm{K}$ and $\mathrm{Al}$ as well as $\mathrm{Fe}$ in REB-00133, which contains enough jarosite and alunite for their deviations from stoichiometry to have a serious effect on the overall evaluation of composition. Other problems of automated mineralogy, such as boundary phases and X-ray interferences, are also likely contributors to the error and to the disparity between QEMSCAN and assay values, but the available data provide no means for assessing their extent in this project. Similarly, unrepresentative sampling or differences in assay and mineralogy splits are also possible but their effects are not currently quantifiable.

Possible errors in leach testing are many and varied; Prosser (1996) lists 30 different variables in leach testing of individual minerals, only 10-12 of which can be controlled or monitored throughout the experiment. Some of the most significant errors come from the disintegration and mechanical abrasion of particles, formation of surface coatings, galvanic effects between particles, and other largely uncontrollable phenomena (Prosser, 1996). For leach tests on rocks, such as this study, the sources of error must be still more numerous, because there is more than one mineral phase available to interact with the fluid. Unfortunately, no articles were found in the literature on the sources or magnitudes of error in bottle roll testing of ground rocks. Some are identifiable on 
principle, such as the errors in titrating kinetic samples to determine reagent concentration. No automatic titrette was available for titrations of sulfuric acid, sulfurous acid, or glycine, so these titrations were done by hand with a $10-\mathrm{mL}$ pipet with gradations at each $0.1 \mathrm{~mL}$. This probably created an error of $5-10 \%$, beyond the error induced by titrating to past the equilibrium point. This in turn likely led to the addition of too little reagent, and hence to leaching at a lower reagent concentration than intended.

Dilution for AA analysis would be another significant source of error in the $\mathrm{Cu}$ measurements, with $5 \%$ cumulative error. This is supported by a comparison of ICP and AA results for $\mathrm{Cu}$ concentration in samples leached with thiourea. Results match very well at low concentrations, but with higher $\mathrm{Cu}$ concentrations the error increases and always shows the AA underestimating $\mathrm{Cu}$ with respect to ICP. This error is augmented by error derived from wavering AA readings, which were not constant but fluctuated by about 0.003 absorbance units over the course of any given measurement. Although every effort was made to use the readings from the middle of this range, they could nevertheless overestimate or underestimate the absorbance values. This is not likely to add significant error to the absorbance values associated with high concentrations, but it probably creates a large error in all of the lower Au measurements. Absorbance values for $<1 \mathrm{ppm}$ Au are typically $<0.008$, meaning that the AA reading error could have been $>50 \%$ for the lower-grade Au samples. This, combined with the statistical calculations for the very small amount of Au in a 200-g split of $0.7 \mathrm{~g} / \mathrm{t}$ ore, is probably responsible for the apparent $>100 \%$ Au recovery in REB-00187 and REB-00188 (Fig. 6b). Recoveries for the two samples with the highest Au grades, REB-00150 and REB-00185, come the closest of all the samples to totaling $100 \%$, which supports the probability that the 
extremely high recoveries for REB-00187 and REB-00188 result from a combination of AA reading error and statistics of small Au quantities.

\section{Conclusions and future work}

The principal conclusion of this study is that no single-step leaching method of those examined here is likely to provide economic recovery of the supergene $\mathrm{Cu}$ and $\mathrm{Au}$ ores at Mike. The results from this first round of testing suggest that the best method would be a combination of leaching $\mathrm{Cu}$ with sulfuric or methanesulfonic acid, followed by Au leaching with thiourea. Sulfurous acid and glycine can be rejected as uneconomic due to low recovery for the reagent consumed.

As was expected, the ore minerals responded in different ways to each reagent. The chrysocolla was leached the best by methanesulfonic acid but yielded less $\mathrm{Cu}$ to sulfuric or sulfuric acid and nearly none to the other reagents. Native $\mathrm{Cu}$ and cuprite gave the best recovery for sulfuric acid leaching, although methanesulfonic acid also performed well and cyanide might be effective at higher concentration. Conichalcite is easily the most problematic of the minerals in the supergene zone, having resisted dissolution by all of the reagents tested. Unfortunately, it is also the most common of the $\mathrm{Cu}$ ores at the Mike deposit, and its refractoriness is a major obstacle the development of any economic leaching method. Future work will focus, in part, on studying the dissolution behavior of conichalcite with rotating-disk electrode tests in order to determine why it is so difficult to dissolve. These results indicate that two of the newer reagents tested have variable promise. The low recovery probably makes glycine 
uneconomic, but methanesulfonic acid may have a bright future in chrysocolla-dominated ore deposits.

\section{Acknowledgments}

Newmont Mining provided background geological data, assays, and samples for this project. Freeport-McMoRan Inc. prepared and analyzed the head and residue samples and donated QEMSCAN time for the mineralogy. The time and expertise shared by Dick Reid and Rachel Burgess (Newmont) and Martin Lyders, Veronica Alejandro, and Casey Cochran (Freeport) is particularly appreciated, as are the guidance and advice of Profs. J. Brent Hiskey, Jinhong Zhang, and Eric Seedorff at the University of Arizona. Prof. Mark Barton (University of Arizona) provided much-appreciated support and constructive critique to the first author.

\section{References}

Ahmed, I., Gbor, P., and Jia, C., 2000. Aqueous sulfur dioxide leaching of $\mathrm{Cu}, \mathrm{Ni}, \mathrm{Co}, \mathrm{Zn}$ and Fe from smelter slag in absence of oxygen. Canadian Journal of Chemical Engineering 78: 694-703.

Aksu, S., and Doyle, F., 2001. Electrochemistry of copper in aqueous glycine solutions. Journal of the Electrochemical Society 148.1: B51-B57.

Arehart, G., 1996. Characteristics and origin of sediment-hosted disseminated gold deposits: A review. Ore Geology Reviews 11: 383-403.

Ayling, B., Rose, P., Petty, S., Zemach, E., and Drakos, P., 2012. QEMSCAN (Quantitative Evaluation of Minerals by Scanning Electron Microscopy): Capability and application to 
fracture characterization in geothermal systems. Proceedings of the $37^{\text {th }}$ Workshop on Geothermal Reservoir Engineering, SGP-TR-194, unpaginated.

Aylmore, M., 2005. Alternative lixiviants to cyanide for leaching gold ores. In Adams, M., ed., Developments in Mineral Processing, vol. 15, Elsevier, 501-539.

Bawden, T., 2002. Supergene enrichment of copper at the Mike gold deposit, Carlin trend, Nevada. Unpublished M.S. thesis, Stanford University, Stanford, CA, 180 p.

Bawden, R., Einaudi, M., Bostick, B., Meibom, A., Wooden, J., Norby, J., Orobona, J., and Chamberlain, C., 2003. Extreme ${ }^{34} \mathrm{~S}$ depletions in $\mathrm{ZnS}$ at the Mike gold deposit, Carlin trend, Nevada: Evidence for bacteriogenic supergene sphalerite. Geology 31.10: 913-916.

Borra, C., Pontikes, Y., Binnemans, K., and van Gerven, T., 2015. Leaching of rare earths from bauxite residue (red mud). Minerals Engineering 76: 20-27.

Botz, M., Fleming, C., and Ford, K., 2011. Cyanide leaching of gold-copper porphyries: chemistry and challenges. World Gold: Proceedings of the $50^{\text {th }}$ annual Conference of Metallurgists of CIM: 285-301.

Breuer, P., Dai, X., and Jeffrey, M, 2005. Leaching of gold and copper minerals in cyanide deficient copper solutions. Hydrometallurgy 78: 156-165.

Chen, C., Lung, T., and Wan, C., 1980. A study of the leaching of gold and silver by acidithioureation. Hydrometallurgy 5: 207-212.

Cline, J., Hofstra, A., Muntean, J., Tosdal, R., and Hickey, K., 2005. Carlin-type gold deposits in Nevada: critical geologic characteristics and viable models. $100^{\text {th }}$ Anniversary Volume of the Society of Economic Geologists: 451-484.

Creelman, R., Gottlieb, P., Jackson, R., and Sutherland, D., 1989. QEM*SEM: a necessary tool in the metallurgical evaluation of ore bodies. AusIMM Mineralogy-Petrology Symposium: $77-79$. 
Das, G., and de Lange, J., 2011. Reductive atmospheric leaching of West Australian smectitic nickel laterite in the presence of sulfur dioxide and copper (II). Hydrometallurgy 105: 264-269.

Davis, A., and Ashenberg, D., 1989. The aqueous geochemistry of the Berkeley pit, Butte, Montana, USA. Applied Geochemistry 4:23-36.

Eksteen, J., and Oraby, E., 2015. The leaching and adsorption of gold using low concentration amino acids and hydrogen peroxide: effect of catalytic ions, sulfide minerals and amino acid type. Minerals Engineering 70: 36-42.

Feng, Q., Wen, S., Zhao, W., Cao, L., and Bai, X., 2015. Leaching of copper from malachite with methane-sulfonic acid. Solvent Extraction Research and Development, Japan 22.2: 159168.

Filmer, A., Lawrence, P., and Hoffman, W., 1984. A comparison of cyanide, thiourea, and chlorine as lixiviants for gold. In Gold-Mining, Extraction, and Geology: AusIMM, 279287.

Gbor, P., Ahmed, I., and Jia, C., 2002. Evaluation of contributions of acid and ligand to Ni, Co, and Fe dissolution from nonferrous smelter slags in aqueous sulfur dioxide. Industrial and Engineering Chemistry Research 41: 1861-1867.

Groenewald, T., 1976. The dissolution of gold in acidic solutions of thiourea. Hydrometallurgy 1: 277-290.

Habashi, F., 1987. One hundred years of cyanidation. CIM Bulletin 80.905: 108-114.

Habashi, F., 2005. A short history of hydrometallurgy. Hydrometallurgy 79: 15-22.

Halpern, J., Milants, H., and Wiles, D., 1959. Kinetics of the dissolution of copper in oxygencontaining solutions of various chelating agents. Journal of the Electrochemical Society 106.8: 657-650. 
Harlan, J., Harris, D., Mallette, P., Norby, J., Rota, J., and Sagar, J., 2002. Geology and mineralization of the Maggie Creek district. In Thompson, T., et al., eds., Gold deposits of the Carlin trend: Nevada Bureau of Mines and Geology Bulletin 111: 115-142.

Hedley, N., and Tabachnick, H., 1958. Chemistry of cyanidation. Mineral Dressing Notes 23: American Cyanamid Co., NY.

Hilson, G., and Monhemius, A., 2006. Alternatives to cyanide in the gold mining industry: what prospects for the future? Journal of Cleaner Production 14.12: 1158-1167.

Hiskey, J., 1981. Thiourea as a lixiviant for gold and silver. AIME preprint 81-79, 9 p.

Hiskey, J., and Atluri, V., 1988. Dissolution chemistry of gold and silver in different lixiviants. Mineral Processing and Extractive Metallurgy Review 4.1-2: 95-134.

Hofstra, A., Snee, L., Rye, R., Folger, H., Phinisey, J., Loranger, R., Dahl, A., Naeser, C., Stein, H., and Lewchuk, M., 1999. Age constraints on Jerritt Canyon and other Carlin-type gold deposits in the western United States - relationship to mid-Tertiary extension and magmatism. Economic Geology 94: 769-802.

Javet, P., and Hintermann, H., 1969. Aspects du comportement de la thiourée en solution cuivrique. Electrochimica Acta 14: 527-532.

Krzewska, S., and Podsiadly, H., 1980. Studies on the reaction of copper(II) with thiourea - I. Silver-silver thiourea electrode for determination of free thiourea concentration in $\mathrm{HClO}_{4}$ medium. Journal of Inorganic and Nuclear Chemistry 42.1: 83-85.

Krzewska, S., Podsiadly, H., and Pajdowski, L., 1980. Studies on the reaction of copper(II) with thiourea - III. Equilibrium and stability constants in $\mathrm{Cu}(\mathrm{II})$-thiourea- $\mathrm{HClO}_{4}$ redox system. Journal of Inorganic and Nuclear Chemistry 42: 89-94.

Kumar, R., Das, S., Ray, R., and Biswas, A., 1993. Leaching of pure and cobalt bearing goethites in sulfurous acid: kinetics and mechanisms. Hydrometallurgy 32: 39-59.

Lacoste-Bouchet, P., Deschenes, G., and Ghali, E., 1998. Thiourea leaching of a copper-gold ore using statistical design. Hydrometallurgy 47: 189-203. 
Li, J., and Miller, J., 2006. A review of gold leaching in acid thiourea solutions. Mineral

Processing and Extractive Metallurgy Review 27.3: 177-214.

Li, J., and Miller, 2007. Reaction kinetics of gold dissolution in acid thiourea solutions using ferric sulfate as oxidant. Hydrometallurgy 89: 279-288.

Low, C., and Walsh, F., 2008. Electrodeposition of tin, copper, and tin-copper alloys from a methanesulfonic acid electrolyte containing a perfluorinated cationic surfactant. Surface and Coatings Technology 202.8: 1339-1349.

Lower, G., and Booth, R., 1965. Cyanidation studies: recovery of copper by cyanidation. AIME Preprint 66B34, $32 \mathrm{p}$.

Majima, H., Awakura, Y., Enami, K., Ueshima, H., and Hirato, T., 1989. Kinetic study of the dissolution of cuprite in oxyacid solutions. Metallurgical Transactions 20B: 573-580.

McInnes, C., Sparrow, G., and Woodcock, J., 1989. Thiourea leaching of gold from an oxidized gold-copper ore. World Gold '89: 36.

Mendes, F., and Martins, A., 2002. Sulfuric acid leaching of Igarapé Bahia gold-copper ore for copper extraction: an ore pretreatment for gold recovery by cyanidation. Minerals and Metallurgical Processing 18.3: 165-168.

Mermillod-Blondin, R., Re, E., Bouzahzah, H., Wilhelmy, J., Benzaazoua, M., and Chopard, A., 2016. Process mineralogy of copper and lead concentrates: uncertainties and metallurgical decisions. Proceedings of the XXVIII International Mineral Processing Congress (unpaginated).

Milants, H., 1958. Kinetics of the dissolution of copper metal in some chelating systems under oxygen pressure. Unpublished M.S. thesis, University of British Columbia, Vancouver, $\mathrm{BC}, 76 \mathrm{p}$.

Muir, D., La Brooy, S., and Cao, C., 1989. Recovery of gold from copper-bearing ores. World Gold '89: 44. 
Norby, J., and Orobona, M., 2002. Geology and mineral systems of the Mike deposit. In:

Thomson, T., et al., eds., Gold deposits of the Carlin trend: Nevada Bureau of Mines and Geology Bulletin 111: 143-167.

Oraby, E., and Eksteen, J., 2014. The selective leaching of copper from gold-copper concentrate in glycine solutions. Hydrometallurgy 150: 14-19.

Oraby, E., and Eksteen, J., 2015. The leaching of gold, silver and their alloys in alkaline glycineperoxide solutions and their adsorption on carbon. Hydrometallurgy 152: 199-203.

Parrish, B., 2014. Petrography and geochemistry of hypogene mineralization at the Mike goldcopper deposit, Eureka County, Nevada. Unpublished M.S. thesis, University of Nevada Reno, $111 \mathrm{p}$.

Pirrie, D., and Rollinson, G., 2011. Unlocking the applications of automated mineral analysis. Geology Today 27.6: 226-235.

Prosser, A., 1996. Review of uncertainty in the collection and interpretation of leaching data. Hydrometallurgy 41: 119-153.

Reid, A., Gottlieb, P., MacDonald, K., and Miller, P., 1984. QEM*SEM image analysis of ore minerals: Volume fraction liberation and observational variances. Applied Mineralogy. Metallurgical Society, AIME 191-204.

Ressel, M., and Henry, C., 2006. Igneous geology of the Carlin trend, Nevada: Development of the Eocene plutonic complex and significance for Carlin-type gold deposits. Economic Geology 101.2: 347-383.

Sceresini, B., 2005. Gold-copper ores. In: Adams, M., ed., Developments in Mineral Processing, vol. 15.32: 789-824.

Seredkin, Y., Aksenov, A., and Senchenko, A., 2014. Searching for technology for complex goldcopper ore treatment. Proceedings of the XXVIII International Mineral Processing Congress, $9 \mathrm{p}$. 
Sullivan, J., 1933. Chemical and physical features of copper leaching. Transactions of the AIME 106: 515-546.

Tanda, B., Eksteen, J., and Oraby, E., 2017. An investigation into the leaching behavior of copper oxide minerals in aqueous alkaline glycine solutions. Hydrometallurgy 167: 153-162.

Teal, L., and Branham, A., 1997. Geology of the Mike gold-copper deposit, Eureka County, Nevada. SEG Guidebook 28: 257-276.

Teal, L., and Jackson, M., 2002. Geologic overview of the Carlin trend gold deposits. Nevada Bureau of Mines and Geology Bulletin 111: 9-19.

Tran, T., Nguyen, H., Hsu, Y., and Wong, P., 1997. Copper-gold interaction during the processing of copper-gold ores. World Gold '97: 95-98.

Vaughan, J., 2004. The process mineralogy of gold: The classification of ore types. Journal of Metallurgy 56.7: 46-48.

Vukcevic, S., 1996. A comparison of alkali and acid methods for the extraction of gold from low grade ores. Minerals Engineering 9.10: 1033-1047.

Wadsworth, M., and Wadia, D., 1955. Reaction rate study of the dissolution of cuprite in sulfuric acid. Transactions of the AIME 209: 755-759.

Warren, I., and Hay, M., 1975. Leaching of iron oxides with aqueous solutions of sulfur dioxide. Transactions of the AIME 84: C49-C53.

Wu, Z., Dreisinger, D., Urch, H., and Fassbender, S., 2014. Fundamental study of lead recovery from cerussite concentrate with methanesulfonic acid (MSA). Hydrometallurgy 142: 2335.

Ye, J.X., and Dow, W.P., 2014. Effect of cupric methanesulfonate on through-hole filling by copper electroplating. Electrochemical Society Meeting Abstracts 33: 1683.

Youzbashi, A., and Dixit, S., 1993. Leaching of $\mathrm{Cu}_{2} \mathrm{O}$ with aqueous solution of sulfur dioxide. Metallurgical Transactions 24B: 564-570. 
Figure 1.

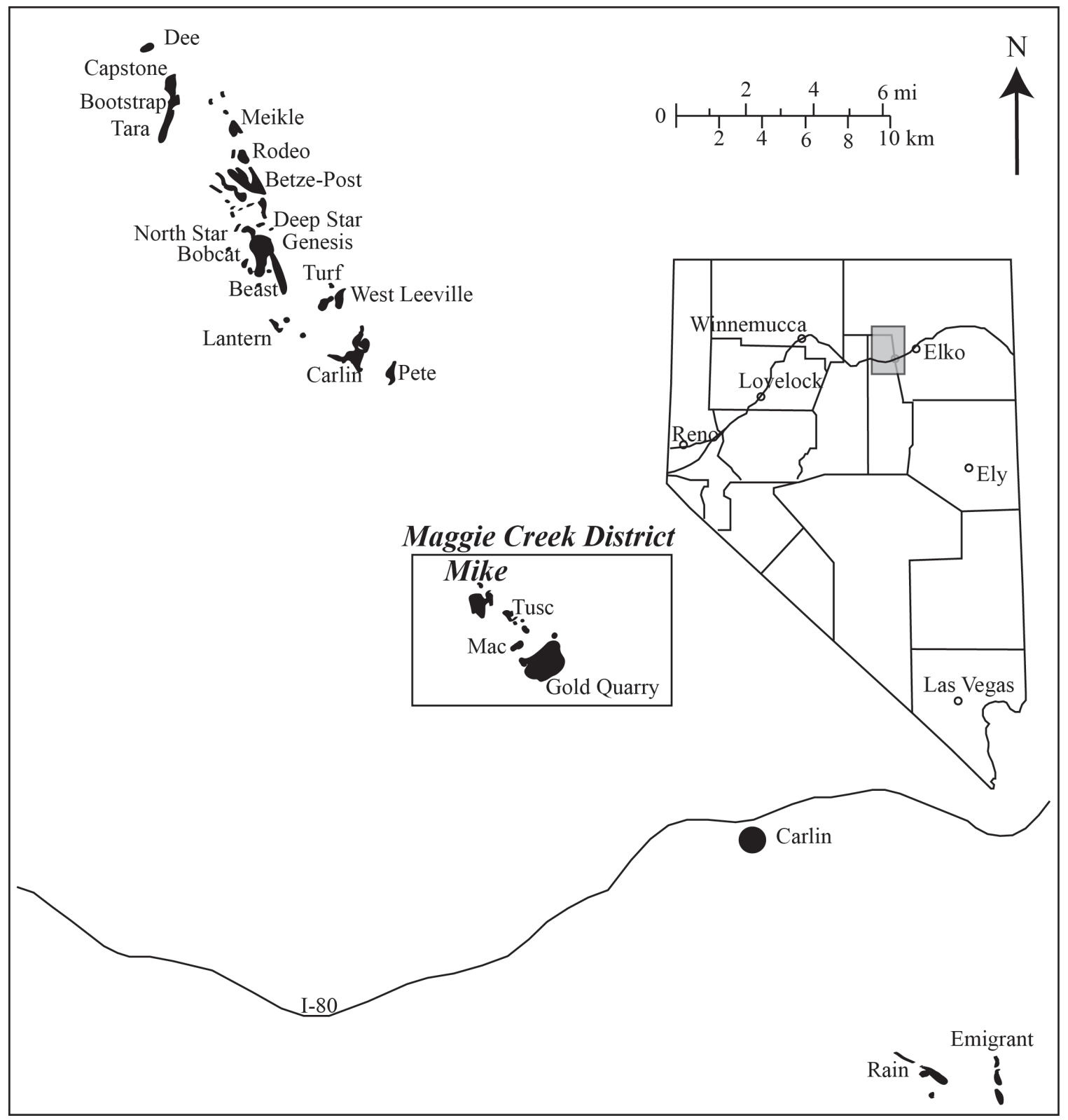


Figure 2.

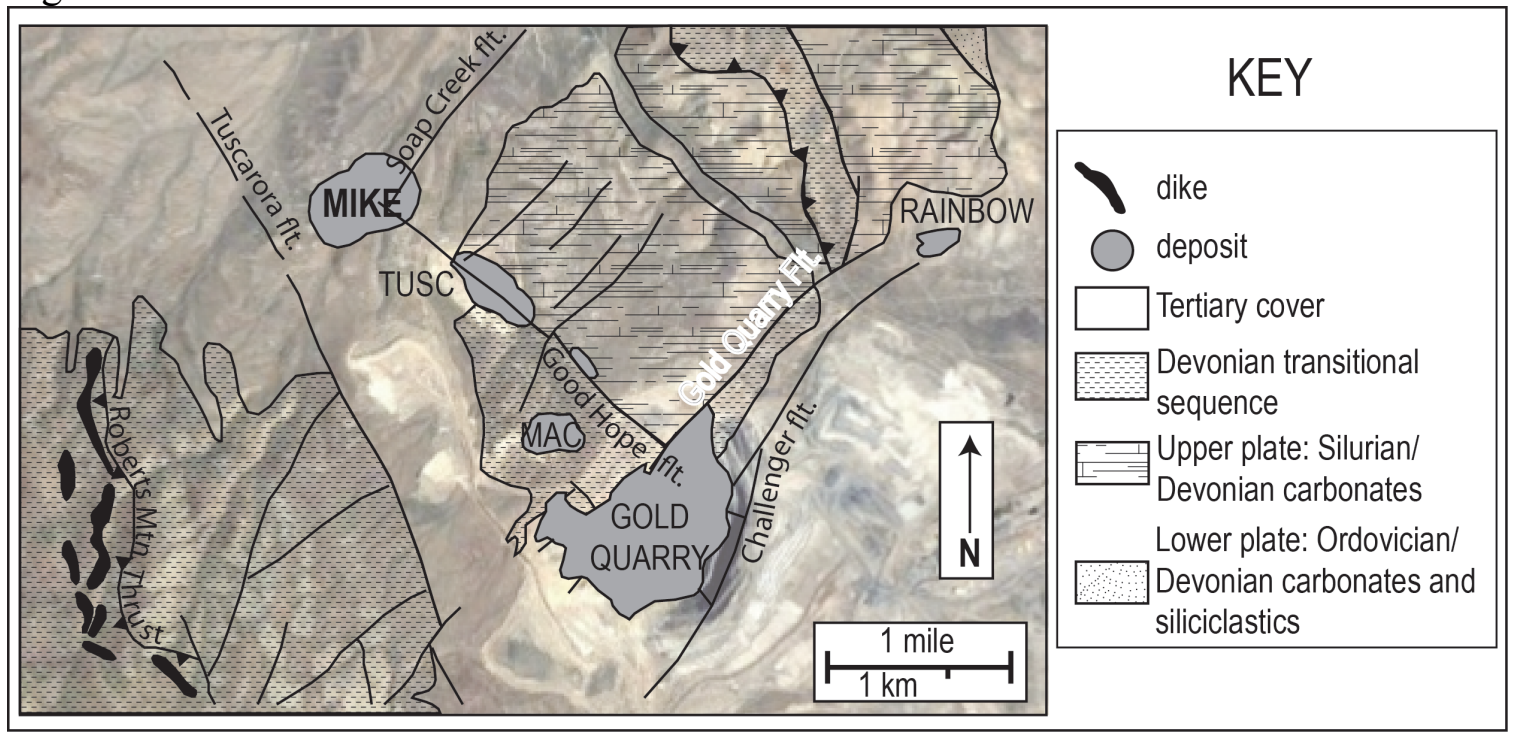


Figure 3.

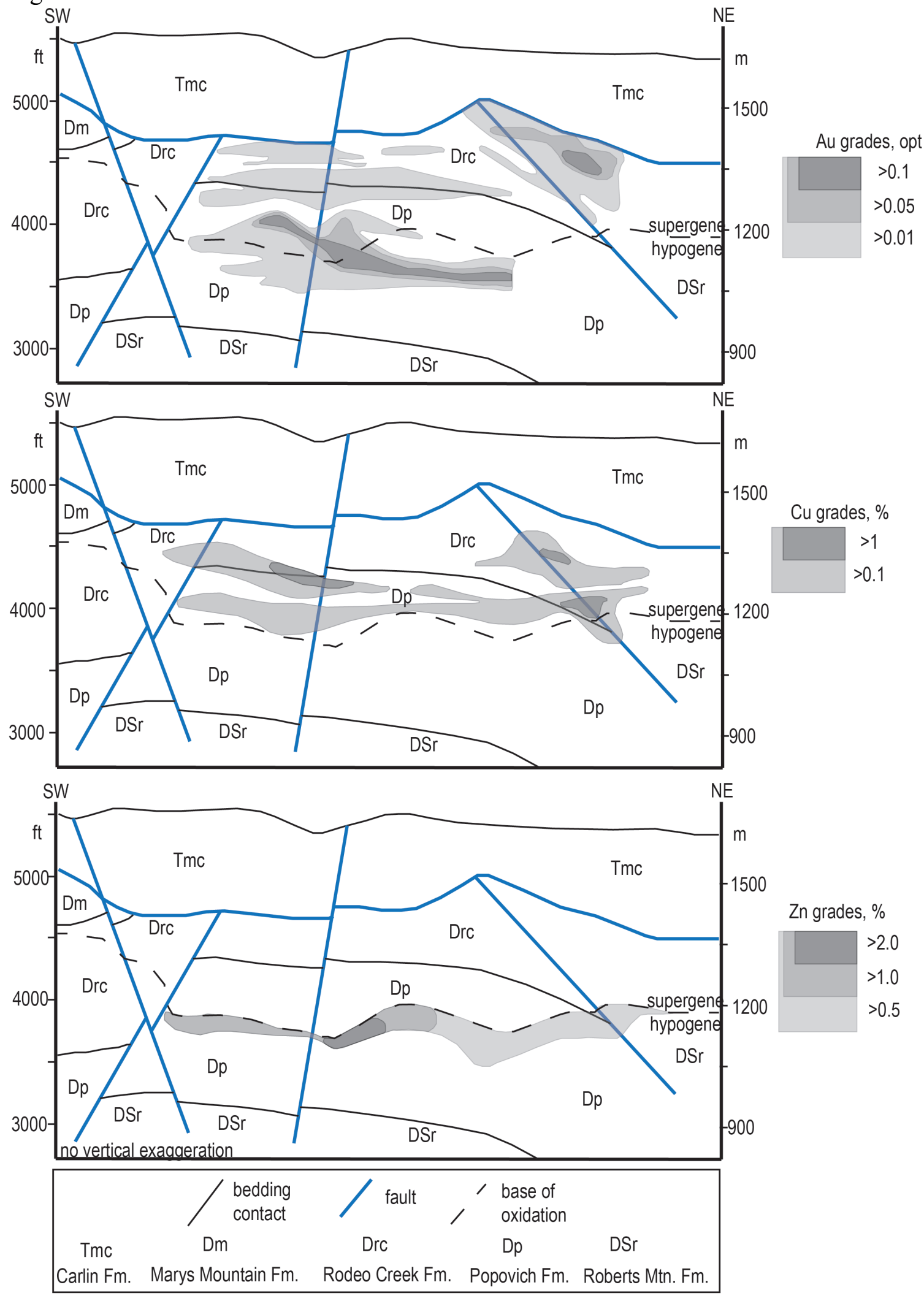


Figure 4.

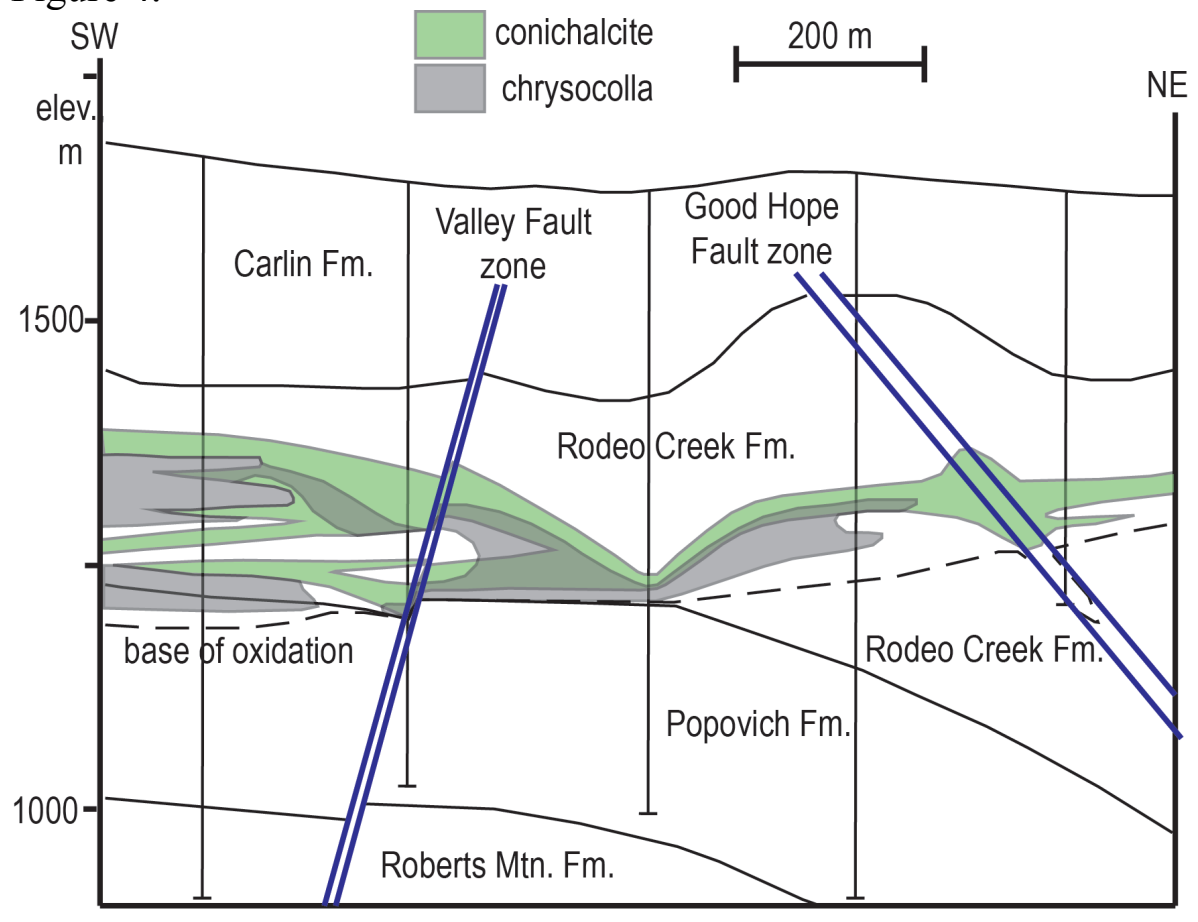


Figure 5.
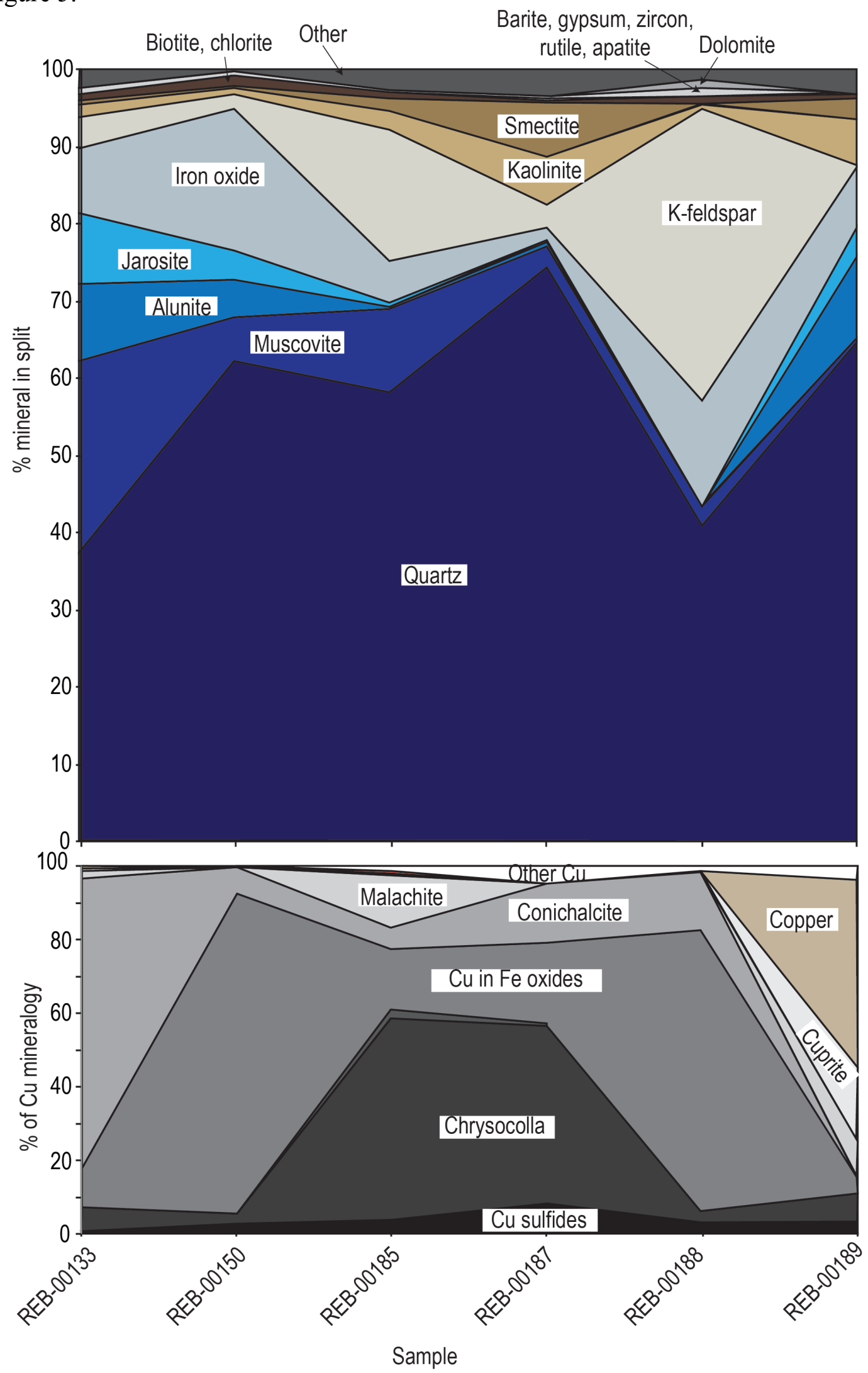
Figure 6A.

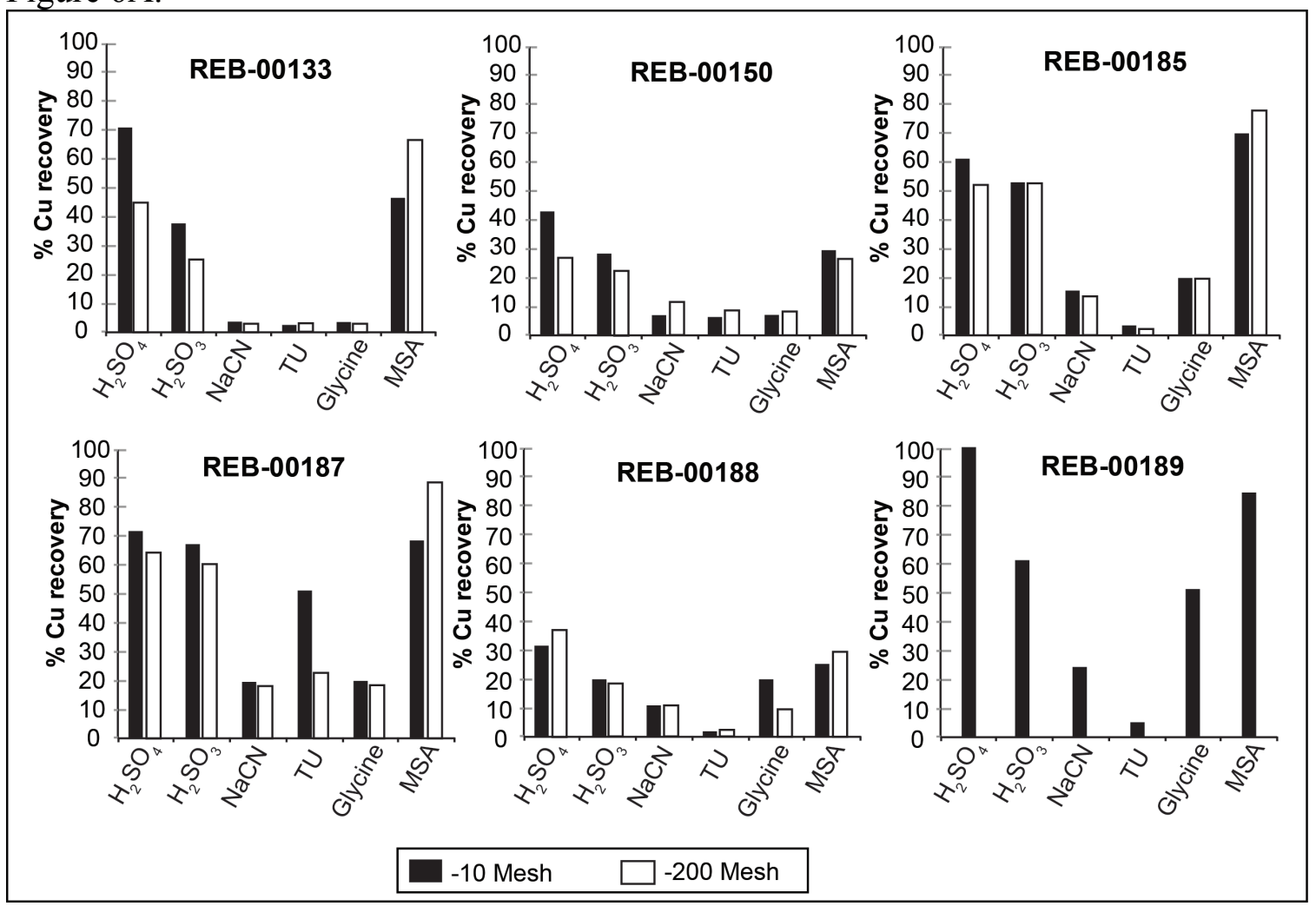


Figure 6B.

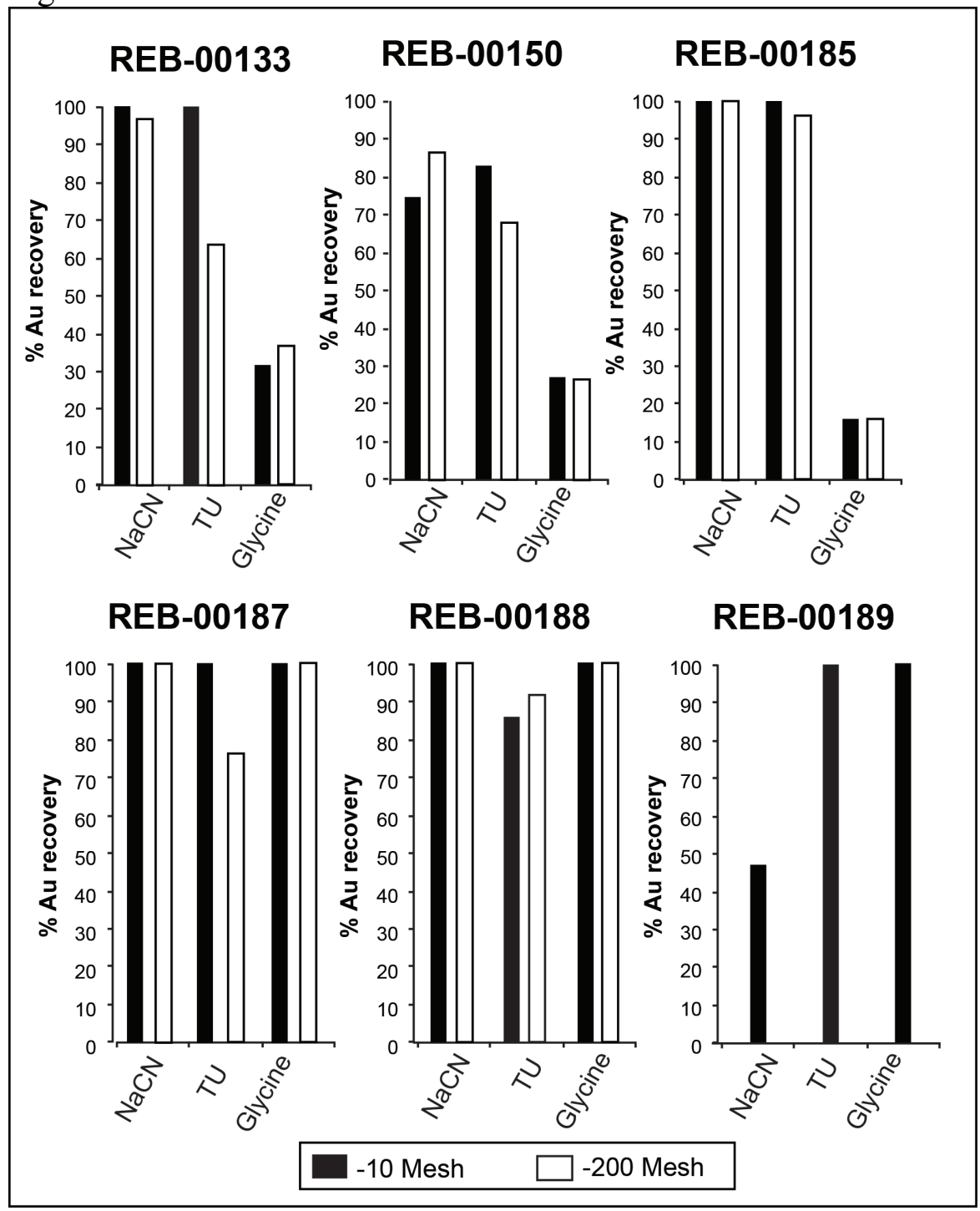


Figure 7.

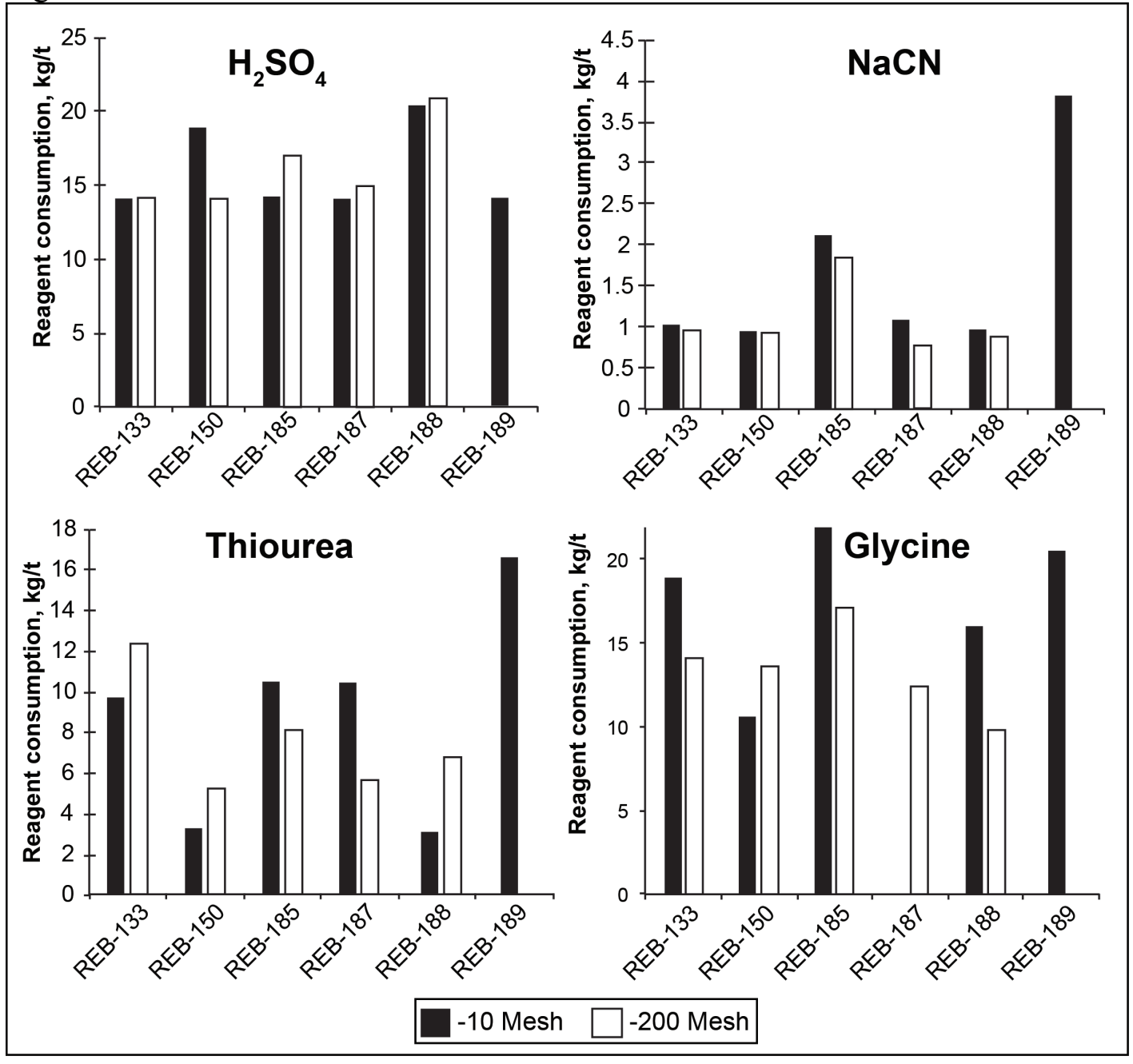


Figure 8.
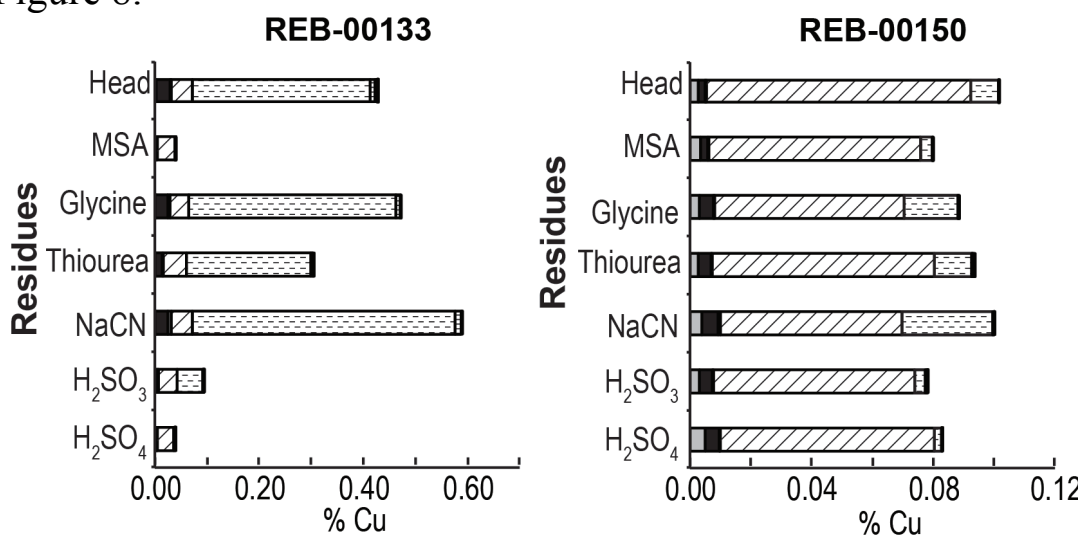

\begin{tabular}{l}
\hline Cu sulfides \\
Chrysocolla \\
$\square$ Cu in Fe oxides \\
Conichalcite \\
Cuprite \\
Native Cu \\
\hline Other $\mathrm{Cu}$
\end{tabular}
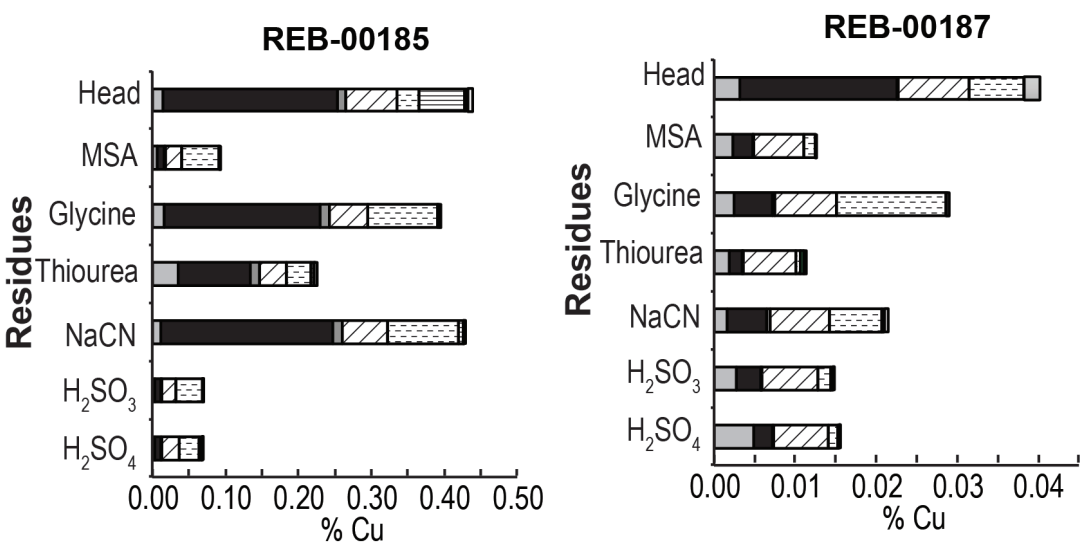

REB-00188
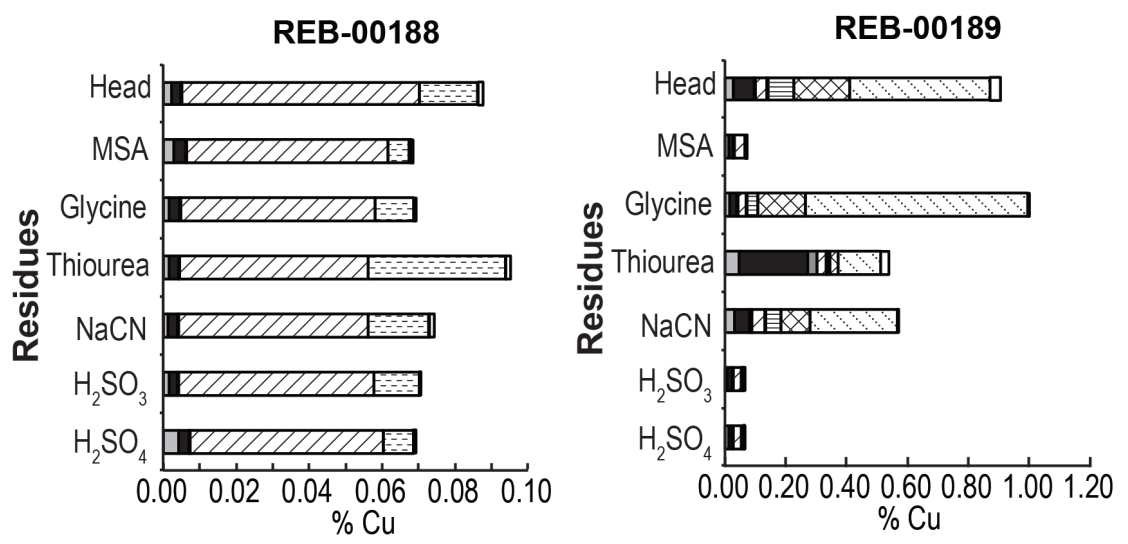
Figure 9.
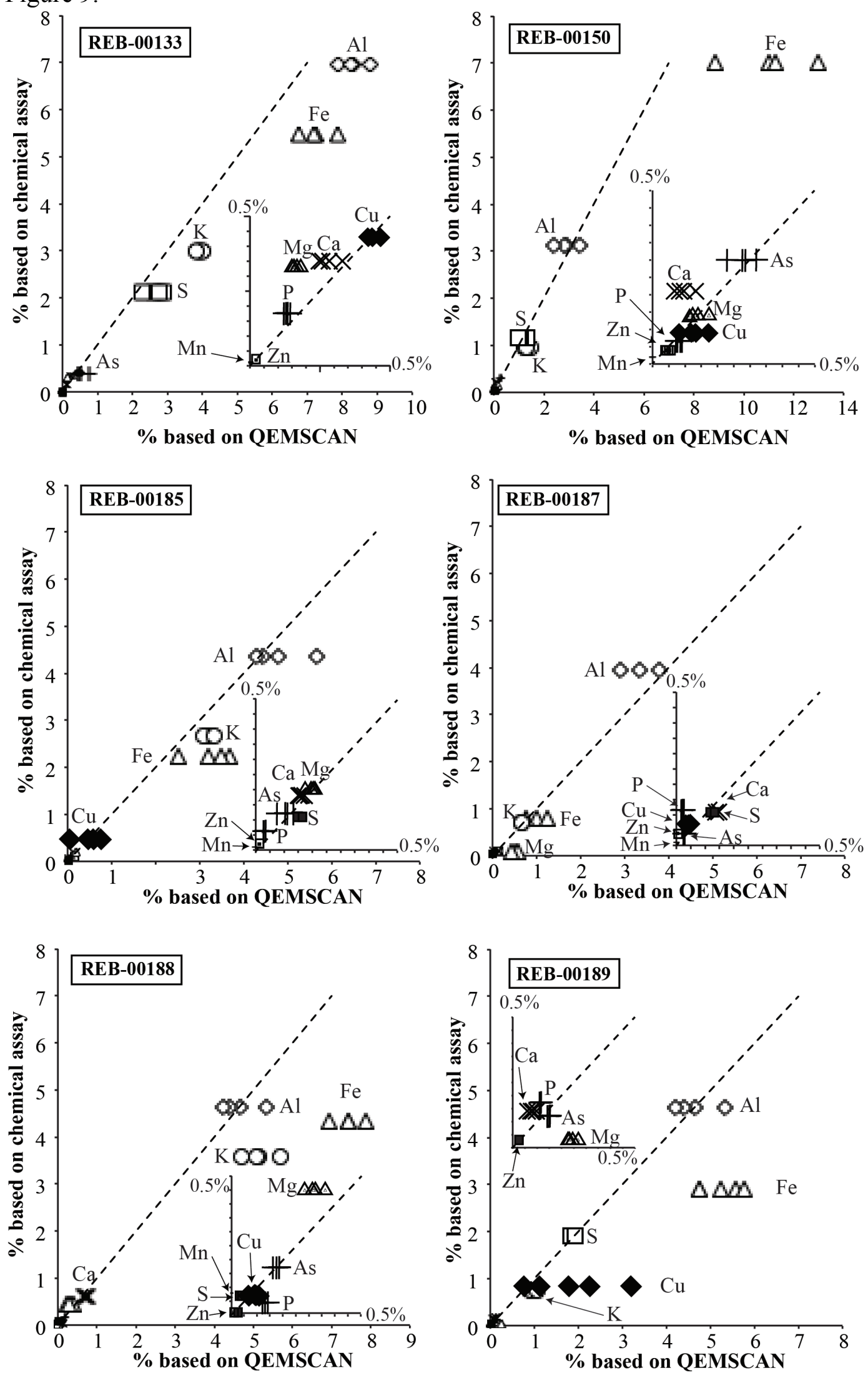
Figure 10.
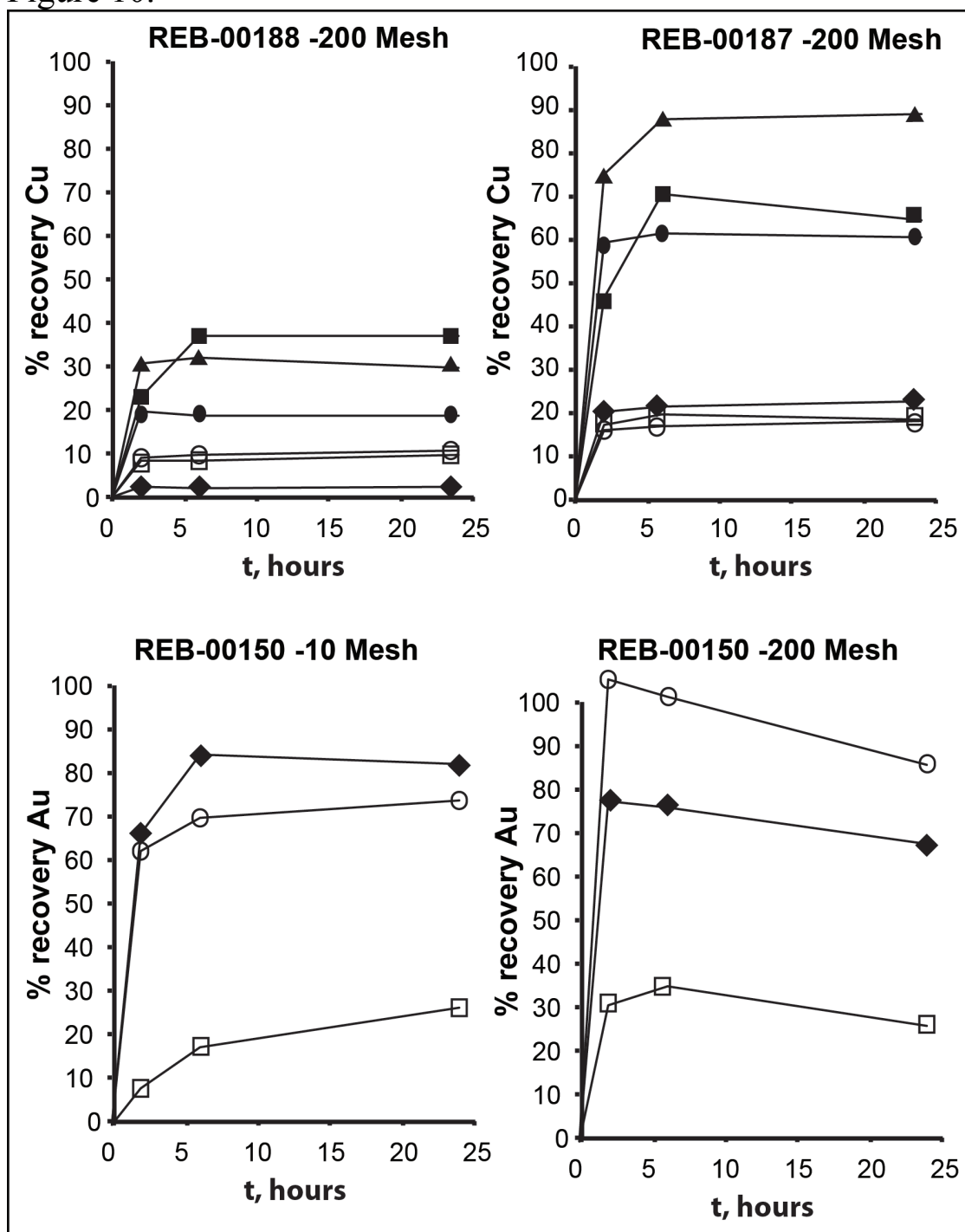

- Sulfuric acid

- Sulfurous acid

O Cyanide

- Thiourea

$\square$ Glycine

- MSA 
Table 1. Summary of reagents and conditions tested in this study.

\begin{tabular}{|c|c|c|c|c|c|}
\hline Lixiviant & Formula & Concentration & Additive & Concentration & $\underset{\text { pH }}{\text { Target }}$ \\
\hline Sulfuric acid & $\mathrm{H}_{2} \mathrm{SO}_{4}$ & $10 \mathrm{~g} / \mathrm{L}$ & $\mathrm{Fe}_{2}\left(\mathrm{SO}_{4}\right)_{3} * 5 \mathrm{H}_{2} \mathrm{O}$ & $5 \mathrm{~g} / \mathrm{L}$ & $<2$ \\
\hline Sulfurous acid & $\mathrm{H}_{2} \mathrm{SO}_{3}$ & $10 \mathrm{~g} / \mathrm{L}$ & $\mathrm{Fe}_{2}\left(\mathrm{SO}_{4}\right)_{3} * 5 \mathrm{H}_{2} \mathrm{O}$ & $5 \mathrm{~g} / \mathrm{L}$ & $<2$ \\
\hline Cyanide & $\mathrm{NaCN}$ & $1000 \mathrm{ppm}$ & none & $\mathrm{n} / \mathrm{a}$ & $>11$ \\
\hline Thiourea & $\mathrm{SCN}\left(\mathrm{NH}_{2}\right)_{2}$ & $10 \mathrm{~g} / \mathrm{L}$ & $\mathrm{Fe}_{2}\left(\mathrm{SO}_{4}\right)_{3} * 5 \mathrm{H}_{2} \mathrm{O}$ & $3 \mathrm{~g} / \mathrm{L}$ & $<2$ \\
\hline Glycine & $\mathrm{C}_{2} \mathrm{H}_{5} \mathrm{NO}_{2}$ & $0.5 \mathrm{M}$ & $\mathrm{H}_{2} \mathrm{O}_{2}$ & $3 \%$ & $>11$ \\
\hline $\begin{array}{l}\text { Methanesulfonic } \\
\text { acid }\end{array}$ & $\mathrm{CH}_{3} \mathrm{SO}_{3} \mathrm{H}$ & $20 \mathrm{~g} / \mathrm{L}$ & $\mathrm{Fe}_{2}\left(\mathrm{SO}_{4}\right)_{3} * 5 \mathrm{H}_{2} \mathrm{O}$ & $5 \mathrm{~g} / \mathrm{L}$ & $<2$ \\
\hline
\end{tabular}

Table 2. Mineralogical characteristics of samples tested in Newmont's sulfuric acid leaching tests.

\begin{tabular}{|c|c|c|c|c|c|c|c|c|c|c|c|}
\hline & \multicolumn{10}{|c|}{ Composite ID } \\
\hline Mineral & Formula & $\mathrm{MC}-1$ & MC-2 & MC-3 & MC-4 & MC-5 & MC-6 & MC-7 & MC-8 & MC-9 & MC-10 \\
\hline alunite & $\mathrm{KAl}_{3}\left(\mathrm{SO}_{4}\right)_{2}(\mathrm{OH})_{6}$ & 7 & 6 & 9 & 3 & 4 & 1 & 3 & 3 & 20 & 11 \\
\hline calcite & $\mathrm{CaCO} 3$ & & & & & 5 & $<1$ & & & & 9 \\
\hline chlorite & $(\mathrm{Mg}, \mathrm{Fe}, \mathrm{Al})_{6}(\mathrm{Al}, \mathrm{Si})_{4} \mathrm{O}_{10}(\mathrm{OH})_{8}$ & $<1$ & $<1$ & & $<1$ & & $<1$ & & & & \\
\hline goethite & $\mathrm{FeO}(\mathrm{OH})$ & & & & & & & & & 4 & 1 \\
\hline hematite & $\mathrm{Fe}_{2} \mathrm{O}_{3}$ & 3 & 6 & 3 & 5 & 8 & 4 & 10 & 8 & 3 & 4 \\
\hline jarosite & $\mathrm{KFe}_{3}\left(\mathrm{SO}_{4}\right)_{2}(\mathrm{OH})_{6}$ & 1 & 3 & 1 & 3 & & 4 & 5 & 3 & 2 & \\
\hline K-feldspar & $\mathrm{KAISi}_{3} \mathrm{O}_{8}$ & 17 & 24 & 27 & 26 & 33 & 37 & 17 & 16 & 5 & 7 \\
\hline kaolinite & $\mathrm{Al}_{2} \mathrm{Si}_{2} \mathrm{O}_{5}(\mathrm{OH})_{4}$ & 11 & 12 & 12 & 12 & 11 & & 11 & 8 & 23 & 12 \\
\hline $\begin{array}{l}\text { mica (muscovite } \\
\text { /sericite or biotite) }\end{array}$ & & 7 & 17 & 6 & 10 & 15 & 13 & 19 & 14 & 5 & 12 \\
\hline pyrite & $\mathrm{FeS}_{2}$ & 2 & $<1$ & 2 & 1 & 1 & 1 & 1 & 2 & 2 & 4 \\
\hline quartz & $\mathrm{SiO}_{2}$ & 53 & 30 & 40 & 41 & 22 & 41 & 34 & 45 & 36 & 40 \\
\hline barite *1 & $\mathrm{BaSO}_{4}$ & $<1$ & 1 & $<1$ & $<1$ & $<1$ & $<1$ & $<1$ & 1 & & \\
\hline sphalerite *1 & ZnS & & & & & $<1$ & $<1$ & $<1$ & $<1$ & & \\
\hline native copper *2 & $\mathrm{Cu}$ & & $x$ & & & $x$ & $x$ & & & $x$ & $x$ \\
\hline malachite & $\mathrm{Cu}_{2} \mathrm{CO}_{3}(\mathrm{OH})_{2}$ & & & & & & & & & & \\
\hline $\begin{array}{l}\text { chalcocite rimming } \\
\text { on pyrite }\end{array}$ & $\mathrm{Cu}_{2} \mathrm{~S}$ & & & & & & & & & $x$ & $x$ \\
\hline
\end{tabular}


Table 3a. Copper recovery from Newmont's sulfuric acid leaching bottle roll tests.

\begin{tabular}{|l|l|l|l|l|l|l|l|l|l|}
\hline ID & $\begin{array}{l}\text { Residue } \\
\mathrm{Cu}, \mathrm{ppm}\end{array}$ & $\begin{array}{l}\text { Calc. } \\
\text { head } \\
\mathrm{Cu}, \\
\mathrm{ppm}\end{array}$ & $\begin{array}{l}\text { Meas. } \\
\text { head } \\
\mathrm{Cu}, \\
\mathrm{ppm}\end{array}$ & $\begin{array}{l}\% \mathrm{Cu} \\
\text { rec., } \\
\text { calc } \\
\text { head }\end{array}$ & $\begin{array}{l}\% \mathrm{Cu} \\
\text { rec., } \\
\text { meas. } \\
\text { head }\end{array}$ & $\begin{array}{l}\mathrm{QLT} \\
\mathrm{Cu}, \\
\mathrm{ppm}\end{array}$ & $\begin{array}{l}\mathrm{kg} / \mathrm{t} \text { acid } \\
\text { consumed }\end{array}$ & $\begin{array}{l}\mathrm{Cu} \\
\text { produced } \\
\mathrm{kg} / \text { ton } \\
\text { ore }\end{array}$ & $\begin{array}{l}\text { Net } \\
\text { acid } \\
\text { cons., } \\
\mathrm{kg} / \mathrm{t}\end{array}$ \\
\hline MC-1 & 732 & 2724 & 2620 & 73.1 & 72.1 & 1999 & 15.0 & 2.0 & 11.8 \\
\hline MC-2 & 3632 & 10215 & 10715 & 64.4 & 66.1 & 8650 & 21.3 & 6.6 & 10.8 \\
\hline MC-3 & 1446 & 2634 & 1671 & 45.1 & 45.9 & 1880 & 16.2 & 1.2 & 14.3 \\
\hline MC-4 & 1958 & 5136 & 5249 & 61.9 & 62.7 & 3355 & 15.7 & 3.2 & 10.6 \\
\hline MC-5 & 3005 & 5793 & 6342 & 48.1 & 52.6 & 3883 & 40.6 & 2.8 & 36.2 \\
\hline MC-6 & 1578 & 2292 & 2565 & 31.2 & 38.5 & 1429 & 28.4 & 0.7 & 27.2 \\
\hline MC-7 & 4893 & 7655 & 6803 & 36.1 & 28.1 & 5798 & 17.4 & 2.8 & 12.9 \\
\hline MC-8 & 1932 & 3840 & 3849 & 49.7 & 49.8 & 2787 & 16.7 & 1.9 & 13.6 \\
\hline
\end{tabular}

Table 3b. Copper recovery from Newmont's sulfuric acid column leaching tests.

\begin{tabular}{|c|c|c|c|c|c|c|c|c|}
\hline & & & \multicolumn{3}{|c|}{ ppm Cu } & & \\
\hline ID & $\begin{array}{c}\text { Cure } \\
\text { acid, } \\
\mathrm{kg} / \mathrm{t}\end{array}$ & $\begin{array}{c}\text { Residue } \\
\mathrm{Cu}, \mathrm{ppm}\end{array}$ & $\begin{array}{c}\text { Calc. } \\
\text { head } \\
\text { sol'n } \\
+ \text { res }\end{array}$ & $\begin{array}{c}\text { Meas. } \\
\text { head } \\
\text { master }\end{array}$ & $\begin{array}{c}\text { Screen } \\
\text { fract. }\end{array}$ & $\begin{array}{c}\text { Weight } \\
\text { loss \% }\end{array}$ & $\begin{array}{c}\text { Extraction \%, } \\
\text { calc. head }\end{array}$ & $\begin{array}{c}\text { Acid consumption, } \\
\mathrm{kg} / \mathrm{t}\end{array}$ \\
\hline MC-1 & 5 & 681 & 2853 & 2620 & 2755 & 2.2 & 76.7 & 7.6 \\
\hline MC-2 & 10 & 1680 & 11844 & 10716 & 11705 & 5.1 & 86.5 & 36.4 \\
\hline MC-3 & 6 & 817 & 3033 & 2671 & 2947 & 3.0 & 73.9 & 15.7 \\
\hline MC-4 & 7 & 1701 & 5606 & 5249 & 5741 & 2.4 & 70.4 & 16.1 \\
\hline MC-5 & 22 & 1671 & 5839 & 6342 & 6446 & 3.0 & 72.2 & 62.7 \\
\hline MC-6 & 15 & 923 & 2698 & 2565 & 2487 & 3.8 & 67.1 & 40.0 \\
\hline MC-7 & 9 & 1776 & 8865 & 6803 & 7624 & 0.2 & 80.0 & 31.1 \\
\hline MC-8 & 6 & 1116 & 5180 & 3849 & 4134 & 4.3 & 79.4 & 21.6 \\
\hline
\end{tabular}

Table 4. Locations and grades of samples used in this study.

\begin{tabular}{|l|l|l|l|l|}
\hline $\begin{array}{c}\text { Drill hole } \\
\text { number }\end{array}$ & \multicolumn{1}{|c|}{$\begin{array}{c}\text { Core interval, } \\
\mathbf{f t}\end{array}$} & \multicolumn{1}{|c|}{ Rock formation } & $\begin{array}{c}\text { Average Au, } \\
\text { opt; } \mathbf{g} / \mathbf{( s h o r t ) ~ t o n}\end{array}$ & $\begin{array}{c}\text { Average } \\
\mathbf{C u} \mathbf{\%}\end{array}$ \\
\hline REB-00133 & $1210-1230$ & Roberts Mountain(?) & $0.114 ; 3.26$ & 0.43 \\
\hline REB-00150 & $960-980$ & Roberts Mountain & $0.132 ; 3.74$ & 0.09 \\
\hline REB-00185 & $1410-1430$ & Popovich & $0.184 ; 5.22$ & 0.48 \\
\hline REB-00187 & $1382-1403.5$ & Rodeo Creek & $0.026 ; 0.748$ & 0.07 \\
\hline REB-00188 & $1042-1062$ & Rodeo Creek & $0.027 ; 0.765$ & 0.07 \\
\hline REB-00189 & $1132-1152$ & Popovich & $0.033 ; 0.936$ & $1.0^{*}$ \\
\hline
\end{tabular}

*Both QEMSCAN and chemical assay \%Cu values show extreme variance due to the nugget effect of large $\mathrm{Cu}$ grains in 3-g mineralogy and 10-g assay splits. Overall \%C in the 200-g samples tested for leaching behavior is estimated at this value but individual splits tested may vary from it. 
Table 5. Iron, copper, and arsenic content of alunite, jarosite, and iron oxides in the Mike samples.

\begin{tabular}{|c|c|c|c|c|c|}
\hline & & $\mathbf{F e}, \mathbf{\%}$ & $\mathbf{C u}, \mathbf{\%}$ & $\mathbf{A s}, \mathbf{\%}$ & $\boldsymbol{n}$ \\
\hline alunite & average & 2.9 & 0.1 & 0.7 & \multirow{4}{*}{44} \\
\cline { 2 - 5 } & median & 1.6 & 0.0 & 0.5 & \\
\cline { 2 - 5 } & min & 0.2 & 0.0 & 0.0 & \\
\cline { 2 - 5 } & max & 13.4 & 1.9 & 3.0 & \\
\hline jarosite & average & 22.4 & 0.1 & 0.5 & \multirow{1}{*}{151} \\
\cline { 2 - 5 } & median & 22.6 & 0.0 & 0.5 & \\
\cline { 2 - 5 } & min & 11.9 & 0.0 & 0.0 & \\
\cline { 2 - 5 } & max & 42.6 & 0.8 & 1.3 & \multirow{2}{*}{16} \\
\hline \multirow{3}{*}{$\begin{array}{c}\text { hematite } \\
\text { and }\end{array}$} & average & 52.8 & 0.7 & 1.8 & \\
\cline { 2 - 5 } & median & 53.2 & 0.6 & 1.8 & \\
\cline { 2 - 5 } & min & 19.6 & 0.0 & 0.0 & \\
\cline { 2 - 5 } & max & 63.6 & 4.4 & 5.6 & \\
\hline
\end{tabular}


Table 6. Results of a QEMSCAN study of the Mike head samples.

\begin{tabular}{|c|c|c|c|c|c|c|}
\hline & $\begin{array}{l}\text { REB- } \\
\text { 00133 }\end{array}$ & $\begin{array}{l}\text { REB- } \\
\text { 00150 }\end{array}$ & $\begin{array}{l}\text { REB- } \\
\text { 00185 }\end{array}$ & $\begin{array}{l}\text { REB- } \\
\text { 00187 }\end{array}$ & $\begin{array}{l}\text { REB- } \\
\text { 00188 }\end{array}$ & $\begin{array}{l}\text { REB- } \\
\text { 00189 }\end{array}$ \\
\hline \multicolumn{7}{|c|}{$\begin{array}{l}\text { Ore and Related Minerals } \\
\end{array}$} \\
\hline $\begin{array}{c}\text { Cu sulfides }\left(\mathrm{Cu}_{2} \mathrm{~S}, \mathrm{CuS}, \mathrm{CuFeS}_{2},\right. \\
\left.\mathrm{Cu}_{5} \mathrm{FeS}_{4}\right)\end{array}$ & -- & -- & 0.02 & -- & -- & 0.03 \\
\hline Sphalerite $(\mathrm{ZnS})$ & -- & -- & -- & -- & -- & -- \\
\hline Pyrite $\left(\mathrm{FeS}_{2}\right)$ & 0.40 & 0.03 & 0.02 & -- & 0.01 & 0.01 \\
\hline Native Copper $(\mathrm{Cu})$ & -- & -- & -- & -- & -- & 0.47 \\
\hline Cuprite $\left(\mathrm{Cu}_{2} \mathrm{O}\right)$ & -- & -- & -- & -- & -- & 0.20 \\
\hline $\begin{array}{l}\text { Chrysocolla }(\mathrm{Cu} \text {-silicate, various } \\
\text { formulas) }\end{array}$ & 0.07 & 0.01 & 0.66 & 0.05 & 0.01 & 0.19 \\
\hline Malachite $\left(\mathrm{Cu}_{2}\left(\mathrm{CO}_{3}\right)(\mathrm{OH})_{2}\right)$ & 0.02 & -- & 0.11 & -- & -- & 0.15 \\
\hline Conichalcite $\left(\mathrm{CaCu}\left(\mathrm{AsO}_{4}\right)(\mathrm{OH})\right)$ & 1.36 & 0.03 & 0.11 & 0.03 & 0.06 & -- \\
\hline Cu in micas and clays (various) & 0.04 & -- & 0.18 & -- & -- & 0.03 \\
\hline Other $\mathrm{Cu}$ & 0.03 & -- & 0.33 & 0.01 & 0.01 & 0.21 \\
\hline \multicolumn{7}{|c|}{ Rock-Forming Minerals } \\
\hline Quartz $\left(\mathrm{SiO}_{2}\right)$ & 37.37 & 62.16 & 58.20 & 74.26 & 40.87 & 64.76 \\
\hline $\begin{array}{c}\text { Plagioclase } \\
\left([\mathrm{Ca}, \mathrm{Na}][\mathrm{Al}, \mathrm{Si}]_{2} \mathrm{Si}_{2} \mathrm{O}_{8}\right)\end{array}$ & 0.28 & 0.05 & 0.16 & 0.41 & 0.08 & 0.20 \\
\hline K-feldspar $\left(\mathrm{KAlSi}_{3} \mathrm{O}_{8}\right)$ & 3.97 & 1.88 & 17.21 & 2.85 & 37.87 & 0.16 \\
\hline Muscovite $\left(\mathrm{KAl}_{3} \mathrm{AlSi}_{3} \mathrm{O}_{10}(\mathrm{OH})_{2}\right)$ & 24.91 & 5.69 & 10.81 & 2.83 & 2.47 & 0.29 \\
\hline $\begin{array}{c}\text { Biotite }(\mathrm{K}(\mathrm{Mg} \\
\left.\mathrm{Fe})_{3} \mathrm{AlSi}_{3} \mathrm{O}_{10}(\mathrm{OH})_{2}\right)\end{array}$ & 0.41 & 0.26 & 0.15 & 0.02 & 0.62 & -- \\
\hline $\begin{array}{c}\text { Chlorite } \\
\left((\mathrm{Mg}, \mathrm{Fe})_{6}(\mathrm{Al}, \mathrm{Si})_{4} \mathrm{O}_{10}(\mathrm{OH})_{6}\right)\end{array}$ & 0.56 & 0.85 & 0.51 & 0.27 & 0.38 & 0.45 \\
\hline Pyrophyllite $\left(\mathrm{Al}_{2} \mathrm{Si}_{4} \mathrm{O}_{10}(\mathrm{OH})_{6}\right)$ & 0.02 & -- & 0.44 & 2.75 & -- & 1.16 \\
\hline Smectite (various formulas) & 0.62 & 0.32 & 1.64 & 7.04 & 0.26 & 2.71 \\
\hline Kaolinite $\left(\mathrm{Al}_{2} \mathrm{Si}_{2} \mathrm{O}_{5}(\mathrm{OH})_{4}\right)$ & 1.64 & 0.89 & 2.42 & 6.13 & 0.42 & 6.03 \\
\hline Gypsum $\left(\mathrm{CaSO}_{4} * 2 \mathrm{H}_{2} \mathrm{O}\right)$ & -- & 0.01 & -- & 0.08 & -- & 0.02 \\
\hline Alunite $\left(\mathrm{KAl}_{3}\left(\mathrm{SO}_{4}\right)_{2}(\mathrm{OH})_{6}\right)$ & 9.95 & 4.88 & 0.33 & 0.60 & -- & 10.61 \\
\hline Jarosite $\left(\mathrm{KFe}_{3}\left(\mathrm{SO}_{4}\right)_{2}(\mathrm{OH})_{6}\right)$ & 9.11 & 3.81 & 0.45 & 0.25 & 0.01 & 3.83 \\
\hline Iron Oxide (various formulas) & 8.35 & 18.33 & 5.26 & 1.67 & 13.64 & 7.91 \\
\hline Calcite $\left(\mathrm{CaCO}_{3}\right)$ & -- & -- & 0.01 & -- & 0.01 & 0.01 \\
\hline Dolomite $\left(\mathrm{CaMg}\left(\mathrm{CO}_{3}\right)_{2}\right)$ & -- & -- & -- & -- & 1.17 & -- \\
\hline $\begin{array}{c}\text { Apatite and sphene } \\
\left.\left(\mathrm{Ca}_{5}\left(\mathrm{PO}_{4}\right)_{3}(\mathrm{~F}, \mathrm{Cl})_{2} \text { and } \mathrm{CaTiSiO}\right)_{5}\right)\end{array}$ & 0.06 & 0.13 & 0.13 & 0.08 & 0.74 & 0.07 \\
\hline Barite $\left(\mathrm{BaSO}_{4}\right)$ & 0.11 & 0.17 & 0.02 & 0.03 & 0.03 & 0.04 \\
\hline Zircon $\left(\mathrm{ZrSiO}_{4}\right)$ & 0.01 & 0.04 & 0.04 & 0.02 & 0.08 & 0.03 \\
\hline $\begin{array}{l}\text { Rutile and ilmenite }\left(\mathrm{TiO}_{2} \text { and }\right. \\
\left.\qquad \mathrm{FeTiO}_{3}\right)\end{array}$ & 0.24 & 0.15 & 0.03 & -- & 0.05 & 0.01 \\
\hline Other & 0.47 & 0.31 & 0.74 & 0.61 & 1.22 & 0.39 \\
\hline Total & $10--$ & $10--$ & 99.98 & 99.99 & 100.01 & 99.97 \\
\hline
\end{tabular}


Table 7. Results of bottle roll testing in this study.

\begin{tabular}{|c|c|c|c|c|c|c|c|}
\hline Sample & Mesh & Reagent & $\begin{array}{l}\text { ppm Cu } \\
\text { in } \\
\text { solution }\end{array}$ & $\begin{array}{c}\text { Cu extraction \% } \\
\text { by head and } \\
\text { solution assays }\end{array}$ & $\begin{array}{l}\text { Account- } \\
\text { ability } \\
\% *\end{array}$ & $\begin{array}{c}\text { ppm } \\
\text { Au in } \\
\text { solution }\end{array}$ & $\begin{array}{c}24 \mathrm{hr} \mathrm{Au} \\
\text { recovery, } \\
\%\end{array}$ \\
\hline Reb-00133 & 10 & $\mathrm{H}_{2} \mathrm{SO}_{4}$ & 2030 & 70.8 & 119.9 & n.a. & n.a. \\
\hline Reb-00150 & 10 & $\mathrm{H}_{2} \mathrm{SO}_{4}$ & 257 & 42.8 & 105 & n.a. & n.a. \\
\hline Reb-00185 & 10 & $\mathrm{H}_{2} \mathrm{SO}_{4}$ & 1953 & 61.0 & 91.2 & n.a. & n.a. \\
\hline Reb-00187 & 10 & $\mathrm{H}_{2} \mathrm{SO}_{4}$ & 334 & 71.6 & 107.3 & n.a. & n.a. \\
\hline Reb-00188 & 10 & $\mathrm{H}_{2} \mathrm{SO}_{4}$ & 147 & 31.4 & 102.8 & n.a. & n.a. \\
\hline Reb-00189 & 10 & $\mathrm{H}_{2} \mathrm{SO}_{4}$ & 5569 & 100 & 115.2 & n.a. & n.a. \\
\hline Reb-00133 & 200 & $\mathrm{H}_{2} \mathrm{SO}_{4}$ & 1283 & 44.8 & n.a. & n.a. & n.a. \\
\hline Reb-00150 & 200 & $\mathrm{H}_{2} \mathrm{SO}_{4}$ & 162 & 27.0 & n.a. & n.a. & n.a. \\
\hline Reb-00185 & 200 & $\mathrm{H}_{2} \mathrm{SO}_{4}$ & 1674 & 52.3 & n.a. & n.a. & n.a. \\
\hline Reb-00187 & 200 & $\mathrm{H}_{2} \mathrm{SO}_{4}$ & 301 & 64.6 & n.a. & n.a. & n.a. \\
\hline Reb-00188 & 200 & $\mathrm{H}_{2} \mathrm{SO}_{4}$ & 173 & 37.1 & n.a. & n.a. & n.a. \\
\hline Reb-00133 & 10 & $\mathrm{H}_{2} \mathrm{SO}_{3}$ & 1077 & 37.6 & 93.8 & n.a. & n.a. \\
\hline Reb-00150 & 10 & $\mathrm{H}_{2} \mathrm{SO}_{3}$ & 169 & 28.2 & 88.2 & n.a. & n.a. \\
\hline Reb-00185 & 10 & $\mathrm{H}_{2} \mathrm{SO}_{3}$ & 1692 & 52.9 & 81.2 & n.a. & n.a. \\
\hline Reb-00187 & 10 & $\mathrm{H}_{2} \mathrm{SO}_{3}$ & 313 & 67.1 & 102.8 & n.a. & n.a. \\
\hline Reb-00188 & 10 & $\mathrm{H}_{2} \mathrm{SO}_{3}$ & 92 & 19.7 & 94 & n.a. & n.a. \\
\hline Reb-00189 & 10 & $\mathrm{H}_{2} \mathrm{SO}_{3}$ & 3385 & 61.2 & 87.3 & n.a. & n.a. \\
\hline Reb-00133 & 200 & $\mathrm{H}_{2} \mathrm{SO}_{3}$ & 718 & 25.0 & n.a. & n.a. & n.a. \\
\hline Reb-00150 & 200 & $\mathrm{H}_{2} \mathrm{SO}_{3}$ & 133 & 22.2 & n.a. & n.a. & n.a. \\
\hline Reb-00185 & 200 & $\mathrm{H}_{2} \mathrm{SO}_{3}$ & 1692 & 52.9 & n.a. & n.a. & n.a. \\
\hline Reb-00187 & 200 & $\mathrm{H}_{2} \mathrm{SO}_{3}$ & 282 & 60.4 & n.a. & n.a. & n.a. \\
\hline Reb-00188 & 200 & $\mathrm{H}_{2} \mathrm{SO}_{3}$ & 87 & 18.6 & n.a. & n.a. & n.a. \\
\hline Reb-00133 & 10 & $\mathrm{NaCN}$ & 107 & 3.7 & 97.5 & 2.7 & 100 \\
\hline Reb-00150 & 10 & $\mathrm{NaCN}$ & 42 & 7.0 & 88.1 & 1.9 & 74.6 \\
\hline Reb-00185 & 10 & $\mathrm{NaCN}$ & 491 & 15.3 & 97.6 & 3.6 & 100 \\
\hline Reb-00187 & 10 & $\mathrm{NaCN}$ & 91 & 19.5 & 110.9 & 0.7 & 100 \\
\hline Reb-00188 & 10 & $\mathrm{NaCN}$ & 50 & 10.7 & 90.7 & 0.6 & 100 \\
\hline Reb-00189 & 10 & $\mathrm{NaCN}$ & 1337 & 24.2 & 118.9 & 0.3 & 47.1 \\
\hline Reb-00133 & 200 & $\mathrm{NaCN}$ & 80 & 2.8 & n.a. & 2.1 & 96.7 \\
\hline Reb-00150 & 200 & $\mathrm{NaCN}$ & 70 & 11.7 & n.a. & 2.2 & 86.4 \\
\hline Reb-00185 & 200 & $\mathrm{NaCN}$ & 439 & 13.7 & n.a. & 3.8 & 100 \\
\hline Reb-00187 & 200 & $\mathrm{NaCN}$ & 85 & 18.2 & n.a. & 0.7 & 100 \\
\hline Reb-00188 & 200 & $\mathrm{NaCN}$ & 51 & 10.9 & n.a. & 0.9 & 100 \\
\hline Reb-00133 & 10 & Thiourea & 69 & 2.4 & 98 & 2.4 & 100 \\
\hline Reb-00150 & 10 & Thiourea & 52 & 8.7 & 93.1 & 2.1 & 82.9 \\
\hline Reb-00185 & 10 & Thiourea & 476 & 14.9 & 108 & 4.5 & 100 \\
\hline Reb-00187 & 10 & Thiourea & 156 & 33.4 & 119.1 & 0.6 & 100 \\
\hline Reb-00188 & 10 & Thiourea & 8 & 1.7 & 100.3 & 1.2 & 100 \\
\hline
\end{tabular}




\begin{tabular}{|c|c|c|c|c|c|c|c|}
\hline Reb-00189 & 10 & Thiourea & 270 & 4.9 & 101.9 & 1.5 & 100 \\
\hline Reb-00133 & 200 & Thiourea & 94 & 3.1 & n.a. & 1.4 & 63.5 \\
\hline Reb-00150 & 200 & Thiourea & 63 & 8.8 & n.a. & 1.7 & 68.2 \\
\hline Reb-00185 & 200 & Thiourea & 152 & 2.5 & n.a. & 3.4 & 96.1 \\
\hline Reb-00187 & 200 & Thiourea & 122 & 22.7 & n.a. & 0.4 & 76.3 \\
\hline Reb-00188 & 200 & Thiourea & 12 & 2.6 & n.a. & 1.2 & 100 \\
\hline Reb-00133 & 10 & Glycine & 98 & 3.4 & 96.4 & 0.7 & 31.8 \\
\hline Reb-00150 & 10 & Glycine & 41 & 6.8 & 90.2 & 0.7 & 27.1 \\
\hline Reb-00185 & 10 & Glycine & 631 & 19.7 & 101.2 & 0.6 & 16.1 \\
\hline Reb-00187 & 10 & Glycine & 92 & 19.7 & 114 & 0.6 & 100 \\
\hline Reb-00188 & 10 & Glycine & 92 & 19.7 & 101.1 & 0.8 & 100 \\
\hline Reb-00189 & 10 & Glycine & 2832 & 51.2 & 96.2 & 0.7 & 100 \\
\hline Reb-00133 & 200 & Glycine & 87 & 3.0 & n.a. & 0.8 & 100 \\
\hline Reb-00150 & 200 & Glycine & 51 & 8.5 & n.a. & 0.7 & 26.7 \\
\hline Reb-00185 & 200 & Glycine & 636 & 19.9 & n.a. & 0.6 & 16.1 \\
\hline Reb-00187 & 200 & Glycine & 87 & 18.6 & n.a. & 0.7 & 100 \\
\hline Reb-00188 & 200 & Glycine & 45 & 9.6 & n.a. & 0.7 & 100 \\
\hline Reb-00133 & 10 & MSA & 1330 & 46.4 & 96.4 & n.a. & n.a. \\
\hline Reb-00150 & 10 & MSA & 176 & 29.3 & 87.1 & n.a. & n.a. \\
\hline Reb-00185 & 10 & MSA & 2234 & 69.8 & 96.1 & n.a. & n.a. \\
\hline Reb-00187 & 10 & MSA & 319 & 68.4 & n.a.** & n.a. & n.a. \\
\hline Reb-00188 & 10 & MSA & 117 & 25.1 & 99.4 & n.a. & n.a. \\
\hline Reb-00189 & 10 & MSA & 4681 & 84.6 & 96.9 & n.a. & n.a. \\
\hline Reb-00133 & 200 & MSA & 1915 & 66.8 & n.a. & n.a. & n.a. \\
\hline Reb-00150 & 200 & MSA & 160 & 26.7 & n.a. & n.a. & n.a. \\
\hline Reb-00185 & 200 & MSA & 2500 & 78.1 & n.a. & n.a. & n.a. \\
\hline Reb-00187 & 200 & MSA & 415 & 88.9 & n.a. & n.a. & n.a. \\
\hline Reb-00188 & 200 & MSA & 138 & 29.6 & n.a. & n.a. & n.a. \\
\hline
\end{tabular}

n.a. = not analyzed

* see text for calculation

**multiple values obtained for $\mathrm{Cu}$ assay in residue 
8A. Mineralogy of residue samples based on QEMSCAN study of the remains of - 10 mesh splits for sulfuric acid.

\begin{tabular}{|c|c|c|c|c|c|c|}
\hline $\mathrm{H}_{2} \mathrm{SO}_{4}$ Leach Residue & $\begin{array}{l}\text { REB- } \\
00133\end{array}$ & $\begin{array}{l}\text { REB- } \\
\text { 00150 }\end{array}$ & $\begin{array}{l}\text { REB- } \\
00185\end{array}$ & $\begin{array}{l}\text { REB- } \\
\text { 00187 }\end{array}$ & $\begin{array}{l}\text { REB- } \\
\text { 00188 }\end{array}$ & $\begin{array}{l}\text { REB- } \\
\text { 00189 }\end{array}$ \\
\hline \multicolumn{7}{|c|}{ Ore and Related Minerals } \\
\hline $\begin{array}{c}\text { Cu sulfides }\left(\mathrm{Cu}_{2} \mathrm{~S}, \mathrm{CuS}, \mathrm{CuFeS}_{2},\right. \\
\left.\mathrm{Cu}_{5} \mathrm{FeS}_{4}\right)\end{array}$ & -- & -- & -- & -- & -- & 0.01 \\
\hline Sphalerite $(\mathrm{ZnS})$ & -- & -- & -- & -- & -- & -- \\
\hline Pyrite $\left(\mathrm{FeS}_{2}\right)$ & 0.23 & 0.02 & 0.03 & -- & 0.18 & 0.01 \\
\hline Native Copper $(\mathrm{Cu})$ & -- & -- & -- & -- & -- & -- \\
\hline Cuprite $\left(\mathrm{Cu}_{2} \mathrm{O}\right)$ & -- & -- & -- & -- & -- & -- \\
\hline $\begin{array}{l}\text { Chrysocolla }(\mathrm{Cu}-\mathrm{silicate} \text {, various } \\
\text { formulas) }\end{array}$ & -- & 0.01 & 0.02 & 0.01 & 0.01 & 0.03 \\
\hline Malachite $\left(\mathrm{Cu}_{2}\left(\mathrm{CO}_{3}\right)(\mathrm{OH})_{2}\right)$ & -- & -- & 0.01 & -- & -- & -- \\
\hline Conichalcite $\left(\mathrm{CaCu}\left(\mathrm{AsO}_{4}\right)(\mathrm{OH})\right)$ & -- & -- & 0.10 & -- & 0.03 & -- \\
\hline $\mathrm{Cu}$ in micas and clays (various) & -- & -- & 0.01 & -- & -- & -- \\
\hline Other $\mathrm{Cu}$ & -- & -- & 0.02 & -- & -- & -- \\
\hline \multicolumn{7}{|c|}{ Rock-Forming Minerals } \\
\hline Quartz $\left(\mathrm{SiO}_{2}\right)$ & 43.58 & 62.64 & 56.57 & 71.10 & 39.97 & 64.88 \\
\hline $\begin{array}{c}\text { Plagioclase } \\
\left([\mathrm{Ca}, \mathrm{Na}][\mathrm{Al}, \mathrm{Si}]_{2} \mathrm{Si}_{2} \mathrm{O}_{8}\right)\end{array}$ & 0.15 & 0.07 & 0.14 & 0.55 & 0.06 & 0.22 \\
\hline K-feldspar $\left(\mathrm{KAlSi}_{3} \mathrm{O}_{8}\right)$ & 3.56 & 3.49 & 18.77 & 3.08 & 40.92 & 0.28 \\
\hline Muscovite $\left(\mathrm{KAl}_{3} \mathrm{AlSi}_{3} \mathrm{O}_{10}(\mathrm{OH})_{2}\right)$ & 25.01 & 5.43 & 13.55 & 3.51 & 3.20 & 0.87 \\
\hline $\begin{array}{c}\text { Biotite }(\mathrm{K}(\mathrm{Mg} \\
\left.\mathrm{Fe})_{3} \mathrm{AlSi}_{3} \mathrm{O}_{10}(\mathrm{OH})_{2}\right)\end{array}$ & 0.29 & 0.21 & 0.13 & 0.02 & 0.88 & -- \\
\hline $\begin{array}{c}\text { Chlorite } \\
\left((\mathrm{Mg}, \mathrm{Fe})_{6}(\mathrm{Al}, \mathrm{Si})_{4} \mathrm{O}_{10}(\mathrm{OH})_{6}\right)\end{array}$ & 0.53 & 1.31 & 0.51 & 0.24 & 0.45 & 0.70 \\
\hline Pyrophyllite $\left(\mathrm{Al}_{2} \mathrm{Si}_{4} \mathrm{O}_{10}(\mathrm{OH})_{6}\right)$ & 0.01 & -- & 0.25 & 3.62 & -- & 0.71 \\
\hline Smectite (various formulas) & 0.53 & 0.22 & 1.52 & 10.24 & 0.22 & 2.79 \\
\hline Kaolinite $\left(\mathrm{Al}_{2} \mathrm{Si}_{2} \mathrm{O}_{5}(\mathrm{OH})_{4}\right)$ & 1.13 & 1.30 & 2.03 & 4.65 & 0.67 & 5.88 \\
\hline Gypsum $\left(\mathrm{CaSO}_{4} * 2 \mathrm{H}_{2} \mathrm{O}\right)$ & 0.05 & -- & 0.03 & 0.05 & 0.10 & 0.02 \\
\hline Alunite $\left(\mathrm{KAl}_{3}\left(\mathrm{SO}_{4}\right)_{2}(\mathrm{OH})_{6}\right)$ & 8.39 & 4.52 & 0.31 & 0.51 & 0.02 & 10.06 \\
\hline Jarosite $\left(\mathrm{KFe}_{3}\left(\mathrm{SO}_{4}\right)_{2}(\mathrm{OH})_{6}\right)$ & 8.42 & 5.01 & 0.40 & 0.27 & 0.60 & 6.32 \\
\hline Iron Oxide (various formulas) & 7.15 & 14.98 & 4.68 & 1.49 & 11.25 & 6.65 \\
\hline Calcite $\left(\mathrm{CaCO}_{3}\right)$ & 0.01 & -- & -- & -- & -- & -- \\
\hline Dolomite $\left(\mathrm{CaMg}\left(\mathrm{CO}_{3}\right)_{2}\right)$ & -- & -- & -- & -- & 0.08 & -- \\
\hline $\begin{array}{c}\text { Apatite and sphene } \\
\left.\left(\mathrm{Ca}_{5}\left(\mathrm{PO}_{4}\right)_{3}(\mathrm{~F}, \mathrm{Cl})_{2} \text { and } \mathrm{CaTiSiO}\right)_{5}\right)\end{array}$ & 0.02 & 0.02 & 0.03 & 0.06 & 0.32 & 0.02 \\
\hline Barite $\left(\mathrm{BaSO}_{4}\right)$ & 0.15 & 0.28 & 0.13 & 0.03 & 0.04 & 0.03 \\
\hline Zircon $\left(\mathrm{ZrSiO}_{4}\right)$ & 0.01 & 0.02 & 0.03 & 0.02 & 0.07 & 0.02 \\
\hline $\begin{array}{l}\text { Rutile and ilmenite }\left(\mathrm{TiO}_{2} \text { and }\right. \\
\left.\qquad \mathrm{FeTiO}_{3}\right)\end{array}$ & 0.22 & 0.11 & 0.02 & 0.01 & 0.03 & 0.02 \\
\hline \begin{tabular}{|l} 
Other \\
\end{tabular} & 0.56 & 0.34 & 0.67 & 0.53 & 0.85 & 0.42 \\
\hline Total & 100.00 & 99.98 & 99.96 & 99.99 & 99.95 & 99.94 \\
\hline
\end{tabular}


8B. Mineralogy of residue samples based on QEMSCAN study of the remains of -10 mesh splits for sulfurous acid.

\begin{tabular}{|c|c|c|c|c|c|c|}
\hline $\mathrm{H}_{2} \mathrm{SO}_{3}$ Leach Residue & $\begin{array}{l}\text { REB- } \\
\text { 00133 }\end{array}$ & $\begin{array}{l}\text { REB- } \\
\text { 00150 }\end{array}$ & $\begin{array}{l}\text { REB- } \\
00185\end{array}$ & $\begin{array}{l}\text { REB- } \\
\text { 00187 }\end{array}$ & $\begin{array}{l}\text { REB- } \\
00188\end{array}$ & $\begin{array}{l}\text { REB- } \\
\text { 00189 }\end{array}$ \\
\hline \multicolumn{7}{|c|}{ Ore and Related Minerals } \\
\hline $\begin{array}{c}\text { Cu sulfides }\left(\mathrm{Cu}_{2} \mathrm{~S}, \mathrm{CuS}, \mathrm{CuFeS}_{2} \text {, }\right. \\
\left.\mathrm{Cu}_{5} \mathrm{FeS}_{4}\right)\end{array}$ & -- & -- & -- & -- & -- & 0.01 \\
\hline Sphalerite $(\mathrm{ZnS})$ & -- & -- & -- & -- & -- & -- \\
\hline Pyrite $\left(\mathrm{FeS}_{2}\right)$ & 0.24 & 0.03 & 0.02 & -- & 0.13 & 0.01 \\
\hline Native Copper $(\mathrm{Cu})$ & -- & -- & -- & -- & -- & -- \\
\hline Cuprite $\left(\mathrm{Cu}_{2} \mathrm{O}\right)$ & -- & -- & -- & -- & -- & -- \\
\hline $\begin{array}{l}\text { Chrysocolla (Cu-silicate, various } \\
\text { formulas) }\end{array}$ & 0.01 & 0.01 & 0.02 & 0.01 & 0.01 & 0.04 \\
\hline Malachite $\left(\mathrm{Cu}_{2}\left(\mathrm{CO}_{3}\right)(\mathrm{OH})_{2}\right)$ & -- & -- & -- & -- & -- & -- \\
\hline Conichalcite $\left(\mathrm{CaCu}\left(\mathrm{AsO}_{4}\right)(\mathrm{OH})\right)$ & 0.20 & 0.01 & 0.13 & 0.01 & 0.05 & -- \\
\hline Cu in micas and clays (various) & 0.01 & -- & 0.02 & -- & -- & 0.01 \\
\hline Other $\mathrm{Cu}$ & -- & -- & 0.01 & -- & -- & 0.01 \\
\hline \multicolumn{7}{|c|}{ Rock-Forming Minerals } \\
\hline Quartz $\left(\mathrm{SiO}_{2}\right)$ & 34.70 & 59.37 & 56.14 & 68.27 & 38.48 & 62.94 \\
\hline $\begin{array}{c}\text { Plagioclase } \\
\left([\mathrm{Ca}, \mathrm{Na}][\mathrm{Al}, \mathrm{Si}]_{2} \mathrm{Si}_{2} \mathrm{O}_{8}\right)\end{array}$ & 0.14 & 0.05 & 0.17 & 0.54 & 0.07 & 0.19 \\
\hline K-feldspar $\left(\mathrm{KAlSi}_{3} \mathrm{O}_{8}\right)$ & 4.01 & 5.13 & 18.03 & 2.92 & 42.31 & 0.26 \\
\hline Muscovite $\left(\mathrm{KAl}_{3} \mathrm{AlSi}_{3} \mathrm{O}_{10}(\mathrm{OH})_{2}\right)$ & 31.27 & 6.27 & 15.25 & 3.51 & 3.11 & 1.09 \\
\hline $\begin{array}{c}\text { Biotite }(\mathrm{K}(\mathrm{Mg} \\
\left.\mathrm{Fe})_{3} \mathrm{AlSi}_{3} \mathrm{O}_{10}(\mathrm{OH})_{2}\right)\end{array}$ & 0.35 & 0.27 & 0.13 & 0.01 & 0.91 & -- \\
\hline $\begin{array}{c}\text { Chlorite } \\
\left((\mathrm{Mg}, \mathrm{Fe})_{6}(\mathrm{Al}, \mathrm{Si})_{4} \mathrm{O}_{10}(\mathrm{OH})_{6}\right)\end{array}$ & 0.51 & 1.39 & 0.61 & 0.27 & 0.47 & 0.82 \\
\hline Pyrophyllite $\left(\mathrm{Al}_{2} \mathrm{Si}_{4} \mathrm{O}_{10}(\mathrm{OH})_{6}\right)$ & 0.01 & -- & 0.22 & 4.26 & -- & 0.61 \\
\hline Smectite (various formulas) & 0.59 & 0.20 & 1.58 & 12.82 & 0.21 & 2.67 \\
\hline Kaolinite $\left(\mathrm{Al}_{2} \mathrm{Si}_{2} \mathrm{O}_{5}(\mathrm{OH})_{4}\right)$ & 1.15 & 1.75 & 2.26 & 4.56 & 0.80 & 5.94 \\
\hline Gypsum $\left(\mathrm{CaSO}_{4} * 2 \mathrm{H}_{2} \mathrm{O}\right)$ & 0.02 & -- & -- & 0.04 & 0.04 & 0.02 \\
\hline Alunite $\left(\mathrm{KAl}_{3}\left(\mathrm{SO}_{4}\right)_{2}(\mathrm{OH})_{6}\right)$ & 8.79 & 4.44 & 0.26 & 0.43 & 0.03 & 11.16 \\
\hline Jarosite $\left(\mathrm{KFe}_{3}\left(\mathrm{SO}_{4}\right)_{2}(\mathrm{OH})_{6}\right)$ & 9.23 & 5.92 & 0.36 & 0.23 & 0.81 & 7.51 \\
\hline Iron Oxide (various formulas) & 7.64 & 14.07 & 3.98 & 1.52 & 11.39 & 6.19 \\
\hline Calcite $\left(\mathrm{CaCO}_{3}\right)$ & -- & -- & -- & -- & -- & -- \\
\hline Dolomite $\left(\mathrm{CaMg}\left(\mathrm{CO}_{3}\right)_{2}\right)$ & -- & -- & -- & -- & 0.03 & -- \\
\hline $\begin{array}{c}\text { Apatite and sphene } \\
\left(\mathrm{Ca}_{5}\left(\mathrm{PO}_{4}\right)_{3}(\mathrm{~F}, \mathrm{Cl})_{2} \text { and } \mathrm{CaTiSiO}_{5}\right)\end{array}$ & 0.01 & 0.02 & 0.05 & 0.05 & 0.26 & 0.02 \\
\hline Barite $\left(\mathrm{BaSO}_{4}\right)$ & 0.36 & 0.59 & 0.03 & 0.02 & 0.04 & 0.03 \\
\hline Zircon $\left(\mathrm{ZrSiO}_{4}\right)$ & 0.01 & 0.02 & 0.02 & 0.02 & 0.06 & 0.02 \\
\hline $\begin{array}{l}\text { Rutile and ilmenite }\left(\mathrm{TiO}_{2} \text { and }\right. \\
\left.\qquad \mathrm{FeTiO}_{3}\right)\end{array}$ & 0.24 & 0.12 & 0.02 & 0.02 & 0.03 & 0.02 \\
\hline $\begin{array}{c}\text { Other } \\
\end{array}$ & 0.51 & 0.34 & 0.65 & 0.50 & 0.76 & 0.39 \\
\hline Total & 100.00 & $10--$ & 99.96 & 100.01 & 100.00 & 99.96 \\
\hline
\end{tabular}


8C. Mineralogy of residue samples based on QEMSCAN study of the remains of -10 mesh splits for cyanide.

\begin{tabular}{|c|c|c|c|c|c|c|}
\hline NaCN Leach Residue & $\begin{array}{l}\text { REB- } \\
00133\end{array}$ & $\begin{array}{l}\text { REB- } \\
\text { 00150 }\end{array}$ & $\begin{array}{l}\text { REB- } \\
00185\end{array}$ & $\begin{array}{l}\text { REB- } \\
\text { 00187 }\end{array}$ & $\begin{array}{l}\text { REB- } \\
\text { 00188 }\end{array}$ & $\begin{array}{l}\text { REB- } \\
\text { 00189 }\end{array}$ \\
\hline \multicolumn{7}{|c|}{ Ore and Related Minerals } \\
\hline $\begin{array}{c}\text { Cu sulfides }\left(\mathrm{Cu}_{2} \mathrm{~S}, \mathrm{CuS}, \mathrm{CuFeS}_{2} \text {, }\right. \\
\left.\mathrm{Cu}_{5} \mathrm{FeS}_{4}\right)\end{array}$ & -- & -- & 0.01 & -- & -- & 0.04 \\
\hline Sphalerite $(\mathrm{ZnS})$ & -- & -- & -- & -- & -- & 0.01 \\
\hline Pyrite $\left(\mathrm{FeS}_{2}\right)$ & 0.22 & 0.02 & 0.02 & -- & 0.01 & 0.02 \\
\hline Native Copper $(\mathrm{Cu})$ & -- & -- & -- & -- & -- & 0.29 \\
\hline Cuprite $\left(\mathrm{Cu}_{2} \mathrm{O}\right)$ & -- & -- & -- & -- & -- & 0.11 \\
\hline $\begin{array}{l}\text { Chrysocolla }(\mathrm{Cu}-\text { silicate, various } \\
\text { formulas) }\end{array}$ & 0.07 & 0.01 & 0.65 & 0.01 & 0.01 & 0.15 \\
\hline Malachite $\left(\mathrm{Cu}_{2}\left(\mathrm{CO}_{3}\right)(\mathrm{OH})_{2}\right)$ & 0.02 & -- & 0.01 & -- & -- & 0.09 \\
\hline Conichalcite $\left(\mathrm{CaCu}\left(\mathrm{AsO}_{4}\right)(\mathrm{OH})\right)$ & 2.03 & 0.11 & 0.38 & 0.02 & 0.06 & -- \\
\hline $\mathrm{Cu}$ in micas and clays (various) & 0.06 & 0.01 & 0.28 & 0.02 & -- & 0.06 \\
\hline Other $\mathrm{Cu}$ & 0.04 & -- & 0.31 & 0.01 & 0.01 & 0.03 \\
\hline \multicolumn{7}{|c|}{ Rock-Forming Minerals } \\
\hline Quartz $\left(\mathrm{SiO}_{2}\right)$ & 34.34 & 59.37 & 56.52 & 68.68 & 37.70 & 64.42 \\
\hline $\begin{array}{c}\text { Plagioclase } \\
\left([\mathrm{Ca}, \mathrm{Na}][\mathrm{A} 1, \mathrm{Si}]_{2} \mathrm{Si}_{2} \mathrm{O}_{8}\right)\end{array}$ & 0.14 & 0.08 & 0.17 & 0.81 & 0.06 & 0.26 \\
\hline K-feldspar $\left(\mathrm{KAlSi}_{3} \mathrm{O}_{8}\right)$ & 3.97 & 5.52 & 17.53 & 3.03 & 42.71 & 0.31 \\
\hline Muscovite $\left(\mathrm{KAl}_{3} \mathrm{AlSi}_{3} \mathrm{O}_{10}(\mathrm{OH})_{2}\right)$ & 29.37 & 7.03 & 13.53 & 3.63 & 3.05 & 0.79 \\
\hline $\begin{array}{c}\text { Biotite }(\mathrm{K}(\mathrm{Mg} \\
\left.\mathrm{Fe})_{3} \mathrm{AlSi}_{3} \mathrm{O}_{10}(\mathrm{OH})_{2}\right)\end{array}$ & 0.35 & 0.25 & 0.12 & 0.01 & 0.93 & -- \\
\hline $\begin{array}{c}\text { Chlorite } \\
\left((\mathrm{Mg}, \mathrm{Fe})_{6}(\mathrm{Al}, \mathrm{Si})_{4} \mathrm{O}_{10}(\mathrm{OH})_{6}\right)\end{array}$ & 0.53 & 1.53 & 0.43 & 0.25 & 0.43 & 0.68 \\
\hline Pyrophyllite $\left(\mathrm{Al}_{2} \mathrm{Si}_{4} \mathrm{O}_{10}(\mathrm{OH})_{6}\right)$ & 0.01 & -- & 0.22 & 3.49 & -- & 0.79 \\
\hline Smectite (various formulas) & 0.59 & 0.20 & 1.39 & 12.18 & 0.20 & 2.57 \\
\hline Kaolinite $\left(\mathrm{Al}_{2} \mathrm{Si}_{2} \mathrm{O}_{5}(\mathrm{OH})_{4}\right)$ & 1.14 & 1.89 & 2.21 & 4.83 & 0.77 & 5.70 \\
\hline Gypsum $\left(\mathrm{CaSO}_{4} * 2 \mathrm{H}_{2} \mathrm{O}\right)$ & 0.01 & 0.01 & -- & 0.04 & -- & 0.06 \\
\hline Alunite $\left(\mathrm{KAl}_{3}\left(\mathrm{SO}_{4}\right)_{2}(\mathrm{OH})_{6}\right)$ & 9.09 & 4.46 & 0.40 & 0.55 & -- & 9.68 \\
\hline Jarosite $\left(\mathrm{KFe}_{3}\left(\mathrm{SO}_{4}\right)_{2}(\mathrm{OH})_{6}\right)$ & 8.94 & 5.44 & 0.34 & 0.27 & 0.01 & 4.76 \\
\hline Iron Oxide (various formulas) & 7.97 & 12.79 & 4.18 & 1.43 & 11.02 & 8.57 \\
\hline Calcite $\left(\mathrm{CaCO}_{3}\right)$ & 0.05 & 0.04 & 0.04 & 0.02 & 0.03 & 0.01 \\
\hline Dolomite $\left(\mathrm{CaMg}\left(\mathrm{CO}_{3}\right)_{2}\right)$ & -- & -- & -- & -- & 1.00 & -- \\
\hline $\begin{array}{c}\text { Apatite and sphene } \\
\left(\mathrm{Ca}_{5}\left(\mathrm{PO}_{4}\right)_{3}(\mathrm{~F}, \mathrm{Cl})_{2} \text { and } \mathrm{CaTiSiO}_{5}\right)\end{array}$ & 0.10 & 0.21 & 0.21 & 0.09 & 0.72 & 0.08 \\
\hline Barite $\left(\mathrm{BaSO}_{4}\right)$ & 0.17 & 0.46 & 0.22 & 0.02 & 0.04 & 0.03 \\
\hline Zircon $\left(\mathrm{ZrSiO}_{4}\right)$ & 0.01 & 0.04 & 0.05 & 0.02 & 0.06 & 0.03 \\
\hline $\begin{array}{l}\text { Rutile and ilmenite }\left(\mathrm{TiO}_{2} \text { and }\right. \\
\left.\mathrm{FeTiO}_{3}\right)\end{array}$ & 0.25 & 0.12 & 0.03 & -- & 0.03 & 0.02 \\
\hline \begin{tabular}{|l|} 
Other \\
\end{tabular} & 0.55 & 0.40 & 0.75 & 0.56 & 1.14 & 0.43 \\
\hline Total & 100.02 & 99.99 & 100.00 & 99.97 & 99.99 & 99.99 \\
\hline
\end{tabular}


8D. Mineralogy of residue samples based on QEMSCAN study of the remains of -10 mesh splits for thiourea.

\begin{tabular}{|c|c|c|c|c|c|c|}
\hline Thiourea Leach Residue & $\begin{array}{l}\text { REB- } \\
\text { 00133 }\end{array}$ & $\begin{array}{l}\text { REB- } \\
\text { 00150 }\end{array}$ & $\begin{array}{l}\text { REB- } \\
00185\end{array}$ & $\begin{array}{l}\text { REB- } \\
\text { 00187 }\end{array}$ & $\begin{array}{l}\text { REB- } \\
\text { 00188 }\end{array}$ & $\begin{array}{l}\text { REB- } \\
\text { 00189 }\end{array}$ \\
\hline \multicolumn{7}{|c|}{ Ore and Related Minerals } \\
\hline $\begin{array}{c}\text { Cu sulfides }\left(\mathrm{Cu}_{2} \mathrm{~S}, \mathrm{CuS}, \mathrm{CuFeS}_{2} \text {, }\right. \\
\left.\mathrm{Cu}_{5} \mathrm{FeS}_{4}\right)\end{array}$ & -- & -- & 0.05 & -- & -- & 0.07 \\
\hline Sphalerite $(\mathrm{ZnS})$ & -- & -- & -- & -- & -- & 0.01 \\
\hline Pyrite $\left(\mathrm{FeS}_{2}\right)$ & 0.23 & 0.02 & 0.05 & 0.01 & 0.15 & 0.03 \\
\hline Native Copper $(\mathrm{Cu})$ & -- & -- & -- & -- & -- & 0.14 \\
\hline Cuprite $\left(\mathrm{Cu}_{2} \mathrm{O}\right)$ & -- & -- & -- & -- & -- & 0.03 \\
\hline $\begin{array}{l}\text { Chrysocolla }(\mathrm{Cu}-\mathrm{silicate} \text {, various } \\
\text { formulas) }\end{array}$ & 0.04 & 0.01 & 0.28 & -- & 0.01 & 0.62 \\
\hline Malachite $\left(\mathrm{Cu}_{2}\left(\mathrm{CO}_{3}\right)(\mathrm{OH})_{2}\right)$ & 0.01 & -- & 0.01 & -- & -- & 0.02 \\
\hline Conichalcite $\left(\mathrm{CaCu}\left(\mathrm{AsO}_{4}\right)(\mathrm{OH})\right)$ & 0.95 & 0.05 & 0.14 & -- & 0.15 & -- \\
\hline Cu in micas and clays (various) & 0.03 & -- & 0.15 & -- & -- & 0.33 \\
\hline Other $\mathrm{Cu}$ & -- & -- & 0.12 & -- & 0.01 & 0.16 \\
\hline \multicolumn{7}{|c|}{ Rock-Forming Minerals } \\
\hline Quartz $\left(\mathrm{SiO}_{2}\right)$ & 33.61 & 55.06 & 56.28 & 67.22 & 38.76 & 63.38 \\
\hline $\begin{array}{c}\text { Plagioclase } \\
\left([\mathrm{Ca}, \mathrm{Na}][\mathrm{Al}, \mathrm{Si}]_{2} \mathrm{Si}_{2} \mathrm{O}_{8}\right)\end{array}$ & 0.13 & 0.06 & 0.09 & 0.58 & 0.06 & 0.17 \\
\hline K-feldspar $\left(\mathrm{KAlSi}_{3} \mathrm{O}_{8}\right)$ & 3.65 & 4.43 & 16.87 & 3.00 & 42.33 & 0.26 \\
\hline Muscovite $\left(\mathrm{KAl}_{3} \mathrm{AlSi}_{3} \mathrm{O}_{10}(\mathrm{OH})_{2}\right)$ & 29.63 & 7.45 & 13.85 & 3.78 & 3.42 & 0.41 \\
\hline $\begin{array}{c}\text { Biotite }(\mathrm{K}(\mathrm{Mg} \\
\left.\mathrm{Fe})_{3} \mathrm{AlSi}_{3} \mathrm{O}_{10}(\mathrm{OH})_{2}\right)\end{array}$ & 0.43 & 0.32 & 0.14 & 0.02 & 0.83 & -- \\
\hline $\begin{array}{c}\text { Chlorite } \\
\left((\mathrm{Mg}, \mathrm{Fe})_{6}(\mathrm{Al}, \mathrm{Si})_{4} \mathrm{O}_{10}(\mathrm{OH})_{6}\right)\end{array}$ & 0.60 & 1.74 & 0.61 & 0.27 & 0.42 & 0.32 \\
\hline Pyrophyllite $\left(\mathrm{Al}_{2} \mathrm{Si}_{4} \mathrm{O}_{10}(\mathrm{OH})_{6}\right)$ & 0.01 & -- & 0.22 & 3.56 & -- & 0.56 \\
\hline Smectite (various formulas) & 0.57 & 0.23 & 1.38 & 13.42 & 0.23 & 1.80 \\
\hline Kaolinite $\left(\mathrm{Al}_{2} \mathrm{Si}_{2} \mathrm{O}_{5}(\mathrm{OH})_{4}\right)$ & 1.21 & 1.88 & 2.00 & 5.29 & 0.62 & 3.94 \\
\hline Gypsum $\left(\mathrm{CaSO}_{4} * 2 \mathrm{H}_{2} \mathrm{O}\right)$ & 0.04 & 0.01 & 0.01 & 0.05 & 0.06 & 0.03 \\
\hline Alunite $\left(\mathrm{KAl}_{3}\left(\mathrm{SO}_{4}\right)_{2}(\mathrm{OH})_{6}\right)$ & 9.08 & 4.93 & 1.13 & 0.53 & 0.04 & 14.61 \\
\hline Jarosite $\left(\mathrm{KFe}_{3}\left(\mathrm{SO}_{4}\right)_{2}(\mathrm{OH})_{6}\right)$ & 9.51 & 7.39 & 1.31 & 0.23 & 0.66 & 6.81 \\
\hline Iron Oxide (various formulas) & 9.10 & 15.60 & 4.59 & 1.43 & 10.93 & 5.81 \\
\hline Calcite $\left(\mathrm{CaCO}_{3}\right)$ & -- & -- & -- & -- & -- & -- \\
\hline Dolomite $\left(\mathrm{CaMg}\left(\mathrm{CO}_{3}\right)_{2}\right)$ & -- & -- & -- & -- & 0.03 & -- \\
\hline $\begin{array}{c}\text { Apatite and sphene } \\
\left(\mathrm{Ca}_{5}\left(\mathrm{PO}_{4}\right)_{3}(\mathrm{~F}, \mathrm{Cl})_{2} \text { and } \mathrm{CaTiSiO}_{5}\right)\end{array}$ & 0.03 & 0.02 & 0.03 & 0.06 & 0.31 & 0.03 \\
\hline Barite $\left(\mathrm{BaSO}_{4}\right)$ & 0.22 & 0.30 & 0.03 & 0.01 & 0.08 & 0.03 \\
\hline Zircon $\left(\mathrm{ZrSiO}_{4}\right)$ & 0.01 & 0.02 & 0.02 & 0.01 & 0.06 & 0.03 \\
\hline $\begin{array}{l}\text { Rutile and ilmenite }\left(\mathrm{TiO}_{2} \text { and }\right. \\
\left.\mathrm{FeTiO}_{3}\right)\end{array}$ & 0.31 & 0.15 & 0.03 & 0.01 & 0.03 & 0.01 \\
\hline \begin{tabular}{|l|} 
Other \\
\end{tabular} & 0.59 & 0.31 & 0.62 & 0.51 & 0.81 & 0.39 \\
\hline Total & 99.99 & 99.98 & 100.01 & 99.99 & 100.00 & 100.00 \\
\hline
\end{tabular}


8E. Mineralogy of residue samples based on QEMSCAN study of the remains of -10 mesh splits for glycine.

\begin{tabular}{|c|c|c|c|c|c|c|}
\hline Glycine Leach Residue & $\begin{array}{l}\text { REB- } \\
00133\end{array}$ & $\begin{array}{l}\text { REB- } \\
\text { 00150 }\end{array}$ & $\begin{array}{l}\text { REB- } \\
\text { 00185 }\end{array}$ & $\begin{array}{l}\text { REB- } \\
\text { 00187 }\end{array}$ & $\begin{array}{l}\text { REB- } \\
\text { 00188 }\end{array}$ & $\begin{array}{l}\text { REB- } \\
\text { 00189 }\end{array}$ \\
\hline \multicolumn{7}{|c|}{ Ore and Related Minerals } \\
\hline $\begin{array}{c}\text { Cu sulfides }\left(\mathrm{Cu}_{2} \mathrm{~S}, \mathrm{CuS}, \mathrm{CuFeS}_{2} \text {, }\right. \\
\left.\mathrm{Cu}_{5} \mathrm{FeS}_{4}\right)\end{array}$ & -- & -- & 0.02 & -- & -- & 0.02 \\
\hline Sphalerite $(\mathrm{ZnS})$ & -- & -- & -- & -- & -- & -- \\
\hline Pyrite $\left(\mathrm{FeS}_{2}\right)$ & 0.19 & 0.02 & 0.02 & -- & 0.01 & 0.01 \\
\hline Native Copper $(\mathrm{Cu})$ & -- & -- & -- & -- & -- & 0.75 \\
\hline Cuprite $\left(\mathrm{Cu}_{2} \mathrm{O}\right)$ & -- & -- & -- & -- & -- & 0.18 \\
\hline $\begin{array}{l}\text { Chrysocolla }(\mathrm{Cu} \text {-silicate, various } \\
\text { formulas) }\end{array}$ & 0.07 & 0.01 & 0.59 & 0.01 & 0.01 & 0.06 \\
\hline Malachite $\left(\mathrm{Cu}_{2}\left(\mathrm{CO}_{3}\right)(\mathrm{OH})_{2}\right)$ & 0.01 & -- & -- & -- & -- & 0.06 \\
\hline Conichalcite $\left(\mathrm{CaCu}\left(\mathrm{AsO}_{4}\right)(\mathrm{OH})\right)$ & 1.60 & 0.07 & 0.37 & 0.05 & 0.04 & -- \\
\hline Cu in micas and clays (various) & 0.05 & 0.01 & 0.30 & 0.01 & -- & 0.01 \\
\hline Other $\mathbf{C u}$ & 0.02 & -- & 0.22 & -- & -- & 0.04 \\
\hline \multicolumn{7}{|c|}{ Rock-Forming Minerals } \\
\hline Quartz $\left(\mathrm{SiO}_{2}\right)$ & 32.65 & 58.05 & 54.14 & 69.49 & 36.58 & 64.90 \\
\hline $\begin{array}{c}\text { Plagioclase } \\
\left([\mathrm{Ca}, \mathrm{Na}][\mathrm{Al}, \mathrm{Si}]_{2} \mathrm{Si}_{2} \mathrm{O}_{8}\right)\end{array}$ & 0.16 & 0.07 & 0.21 & 0.75 & 0.09 & 0.22 \\
\hline K-feldspar $\left(\mathrm{KAlSi}_{3} \mathrm{O}_{8}\right)$ & 4.51 & 5.86 & 18.07 & 3.26 & 42.99 & 0.40 \\
\hline Muscovite $\left(\mathrm{KAl}_{3} \mathrm{AlSi}_{3} \mathrm{O}_{10}(\mathrm{OH})_{2}\right)$ & 33.12 & 7.16 & 15.68 & 3.71 & 3.19 & 1.08 \\
\hline $\begin{array}{c}\text { Biotite }(\mathrm{K}(\mathrm{Mg} \\
\left.\mathrm{Fe})_{3} \mathrm{AlSi}_{3} \mathrm{O}_{10}(\mathrm{OH})_{2}\right)\end{array}$ & 0.36 & 0.24 & 0.13 & 0.02 & 0.99 & -- \\
\hline $\begin{array}{c}\text { Chlorite } \\
\left((\mathrm{Mg}, \mathrm{Fe})_{6}(\mathrm{Al}, \mathrm{Si})_{4} \mathrm{O}_{10}(\mathrm{OH})_{6}\right)\end{array}$ & 0.50 & 1.56 & 0.48 & 0.28 & 0.56 & 0.68 \\
\hline Pyrophyllite $\left(\mathrm{Al}_{2} \mathrm{Si}_{4} \mathrm{O}_{10}(\mathrm{OH})_{6}\right)$ & 0.01 & -- & 0.16 & 3.65 & -- & 0.62 \\
\hline Smectite (various formulas) & 0.66 & 0.22 & 1.50 & 10.54 & 0.21 & 2.46 \\
\hline Kaolinite $\left(\mathrm{Al}_{2} \mathrm{Si}_{2} \mathrm{O}_{5}(\mathrm{OH})_{4}\right)$ & 1.21 & 2.03 & 2.02 & 5.18 & 0.76 & 5.65 \\
\hline Gypsum $\left(\mathrm{CaSO}_{4} * 2 \mathrm{H}_{2} \mathrm{O}\right)$ & -- & 0.01 & -- & 0.06 & -- & 0.03 \\
\hline Alunite $\left(\mathrm{KAl}_{3}\left(\mathrm{SO}_{4}\right)_{2}(\mathrm{OH})_{6}\right)$ & 7.39 & 4.52 & 0.37 & 0.50 & -- & 9.94 \\
\hline Jarosite $\left(\mathrm{KFe}_{3}\left(\mathrm{SO}_{4}\right)_{2}(\mathrm{OH})_{6}\right)$ & 8.86 & 5.57 & 0.32 & 0.25 & 0.02 & 6.45 \\
\hline Iron Oxide (various formulas) & 7.06 & 13.21 & 4.31 & 1.56 & 11.33 & 5.80 \\
\hline Calcite $\left(\mathrm{CaCO}_{3}\right)$ & -- & -- & 0.01 & -- & 0.02 & -- \\
\hline Dolomite $\left(\mathrm{CaMg}\left(\mathrm{CO}_{3}\right)_{2}\right)$ & -- & -- & -- & -- & 1.15 & -- \\
\hline $\begin{array}{c}\text { Apatite and sphene } \\
\left.\left(\mathrm{Ca}_{5}\left(\mathrm{PO}_{4}\right)_{3}(\mathrm{~F}, \mathrm{Cl})_{2} \text { and } \mathrm{CaTiSiO}\right)_{5}\right)\end{array}$ & 0.10 & 0.16 & 0.22 & 0.08 & 0.80 & 0.10 \\
\hline Barite $\left(\mathrm{BaSO}_{4}\right)$ & 0.62 & 0.71 & 0.03 & 0.02 & 0.05 & 0.04 \\
\hline Zircon $\left(\mathrm{ZrSiO}_{4}\right)$ & 0.01 & 0.04 & 0.05 & 0.02 & 0.06 & 0.03 \\
\hline $\begin{array}{l}\text { Rutile and ilmenite }\left(\mathrm{TiO}_{2} \text { and }\right. \\
\left.\qquad \mathrm{FeTiO}_{3}\right)\end{array}$ & 0.27 & 0.13 & 0.02 & -- & 0.04 & 0.02 \\
\hline \begin{tabular}{|c|} 
Other \\
\end{tabular} & 0.54 & 0.35 & 0.72 & 0.54 & 1.13 & 0.44 \\
\hline Total & 99.97 & 100.00 & 99.96 & 99.98 & 100.03 & 99.99 \\
\hline
\end{tabular}


8F. Mineralogy of residue samples based on QEMSCAN study of the remains of -10 mesh splits for methanesulfonic acid.

\begin{tabular}{|c|c|c|c|c|c|c|}
\hline $\begin{array}{l}\text { Methanesulfonic Acid Leach } \\
\text { Residue }\end{array}$ & $\begin{array}{l}\text { REB- } \\
00133\end{array}$ & $\begin{array}{l}\text { REB- } \\
\text { 00150 }\end{array}$ & $\begin{array}{l}\text { REB- } \\
00185\end{array}$ & $\begin{array}{l}\text { REB- } \\
\text { 00187 }\end{array}$ & $\begin{array}{l}\text { REB- } \\
00188\end{array}$ & $\begin{array}{l}\text { REB- } \\
\text { 00189 }\end{array}$ \\
\hline \multicolumn{7}{|c|}{$\begin{array}{l}\text { Ore and Related Minerals } \\
\end{array}$} \\
\hline $\begin{array}{c}\text { Cu sulfides }\left(\mathrm{Cu}_{2} \mathrm{~S}, \mathrm{CuS}, \mathrm{CuFeS}_{2},\right. \\
\left.\mathrm{Cu}_{5} \mathrm{FeS}_{4}\right)\end{array}$ & -- & -- & 0.01 & -- & -- & 0.01 \\
\hline Sphalerite $(\mathrm{ZnS})$ & -- & -- & -- & -- & -- & -- \\
\hline Pyrite $\left(\mathrm{FeS}_{2}\right)$ & 0.21 & 0.02 & 0.03 & 0.01 & 0.06 & 0.01 \\
\hline Native Copper $(\mathrm{Cu})$ & -- & -- & -- & -- & -- & -- \\
\hline Cuprite $\left(\mathrm{Cu}_{2} \mathrm{O}\right)$ & -- & -- & -- & -- & -- & -- \\
\hline $\begin{array}{l}\text { Chrysocolla }(\mathrm{Cu} \text {-silicate, various } \\
\text { formulas) }\end{array}$ & -- & 0.01 & 0.03 & 0.01 & 0.01 & 0.04 \\
\hline Malachite $\left(\mathrm{Cu}_{2}\left(\mathrm{CO}_{3}\right)(\mathrm{OH})_{2}\right)$ & -- & -- & -- & -- & -- & -- \\
\hline Conichalcite $\left(\mathrm{CaCu}\left(\mathrm{AsO}_{4}\right)(\mathrm{OH})\right)$ & -- & 0.01 & 0.19 & 0.01 & 0.02 & -- \\
\hline Cu in micas and clays (various) & -- & -- & 0.02 & -- & -- & 0.01 \\
\hline Other $\mathrm{Cu}$ & -- & -- & 0.01 & -- & -- & -- \\
\hline \multicolumn{7}{|c|}{ Rock-Forming Minerals } \\
\hline Quartz $\left(\mathrm{SiO}_{2}\right)$ & 31.30 & 55.37 & 57.81 & 72.59 & 40.22 & 66.74 \\
\hline $\begin{array}{c}\text { Plagioclase } \\
\left([\mathrm{Ca}, \mathrm{Na}][\mathrm{A} 1, \mathrm{Si}]_{2} \mathrm{Si}_{2} \mathrm{O}_{8}\right)\end{array}$ & 0.13 & 0.07 & 0.16 & 0.51 & 0.06 & 0.22 \\
\hline K-feldspar $\left(\mathrm{KAlSi}_{3} \mathrm{O}_{8}\right)$ & 4.70 & 5.80 & 18.45 & 3.35 & 41.08 & 0.43 \\
\hline Muscovite $\left(\mathrm{KAl}_{3} \mathrm{AlSi}_{3} \mathrm{O}_{10}(\mathrm{OH})_{2}\right)$ & 34.52 & 6.45 & 12.60 & 3.80 & 2.86 & 0.72 \\
\hline $\begin{array}{c}\text { Biotite }(\mathrm{K}(\mathrm{Mg} \\
\left.\mathrm{Fe})_{3} \mathrm{AlSi}_{3} \mathrm{O}_{10}(\mathrm{OH})_{2}\right)\end{array}$ & 0.37 & 0.22 & 0.13 & 0.01 & 0.98 & -- \\
\hline $\begin{array}{c}\text { Chlorite } \\
\left((\mathrm{Mg}, \mathrm{Fe})_{6}(\mathrm{Al}, \mathrm{Si})_{4} \mathrm{O}_{10}(\mathrm{OH})_{6}\right)\end{array}$ & 0.58 & 1.93 & 0.51 & 0.22 & 0.40 & 0.65 \\
\hline Pyrophyllite $\left(\mathrm{Al}_{2} \mathrm{Si}_{4} \mathrm{O}_{10}(\mathrm{OH})_{6}\right)$ & 0.01 & -- & 0.28 & 3.11 & -- & 0.72 \\
\hline Smectite (various formulas) & 0.63 & 0.18 & 1.53 & 9.52 & 0.24 & 2.46 \\
\hline Kaolinite $\left(\mathrm{Al}_{2} \mathrm{Si}_{2} \mathrm{O}_{5}(\mathrm{OH})_{4}\right)$ & 1.27 & 2.09 & 2.03 & 4.19 & 0.49 & 5.51 \\
\hline Gypsum $\left(\mathrm{CaSO}_{4} * 2 \mathrm{H}_{2} \mathrm{O}\right)$ & 0.04 & -- & -- & 0.03 & 0.04 & 0.03 \\
\hline Alunite $\left(\mathrm{KAl}_{3}\left(\mathrm{SO}_{4}\right)_{2}(\mathrm{OH})_{6}\right)$ & 8.09 & 4.64 & 0.34 & 0.48 & 0.01 & 9.20 \\
\hline Jarosite $\left(\mathrm{KFe}_{3}\left(\mathrm{SO}_{4}\right)_{2}(\mathrm{OH})_{6}\right)$ & 9.61 & 7.10 & 0.43 & 0.27 & 0.26 & 5.41 \\
\hline Iron Oxide (various formulas) & 7.63 & 14.78 & 4.65 & 1.29 & 11.69 & 7.30 \\
\hline Calcite $\left(\mathrm{CaCO}_{3}\right)$ & -- & -- & -- & -- & -- & -- \\
\hline Dolomite $\left(\mathrm{CaMg}\left(\mathrm{CO}_{3}\right)_{2}\right)$ & -- & -- & -- & -- & 0.05 & -- \\
\hline $\begin{array}{c}\text { Apatite and sphene } \\
\left(\mathrm{Ca}_{5}\left(\mathrm{PO}_{4}\right)_{3}(\mathrm{~F}, \mathrm{Cl})_{2} \text { and } \mathrm{CaTiSiO}_{5}\right)\end{array}$ & 0.01 & 0.02 & 0.03 & 0.04 & 0.33 & 0.03 \\
\hline Barite $\left(\mathrm{BaSO}_{4}\right)$ & 0.13 & 0.84 & 0.03 & 0.02 & 0.04 & 0.03 \\
\hline Zircon $\left(\mathrm{ZrSiO}_{4}\right)$ & 0.01 & 0.03 & 0.03 & 0.02 & 0.07 & 0.02 \\
\hline $\begin{array}{l}\text { Rutile and ilmenite }\left(\mathrm{TiO}_{2} \text { and }\right. \\
\left.\qquad \mathrm{FeTiO}_{3}\right)\end{array}$ & 0.25 & 0.11 & 0.02 & -- & 0.04 & 0.02 \\
\hline $\begin{array}{c}\text { Other } \\
\end{array}$ & 0.49 & 0.33 & 0.67 & 0.52 & 1.03 & 0.42 \\
\hline Total & 99.98 & 100.00 & 99.99 & 100.00 & 99.98 & 99.98 \\
\hline
\end{tabular}

